\title{
Centrally Active Multitarget Anti-Alzheimer Agents Derived from the Antioxidant Lead CR-6
}

F. Javier Pérez-Areales, María Garrido, Ester Aso, Manuela Bartolini, Angela De Simone, Alba Espargaró, Tiziana Ginex, Raimon Sabate, Belén Pérez, Vincenza Andrisano, Dolors Puigoriol-Illamola, Mercè Pallàs, F. Javier Luque, María Isabel Loza, José Brea, Isidro Ferrer, Francisco Ciruela, Angel Messeguer, and Diego Muñoz-Torrero*

Cite This: J. Med. Chem. 2020, 63, 9360-9390

Read Online

ACCESS | Lلll Metrics \& More | 国 Article Recommendations | sl Supporting Information

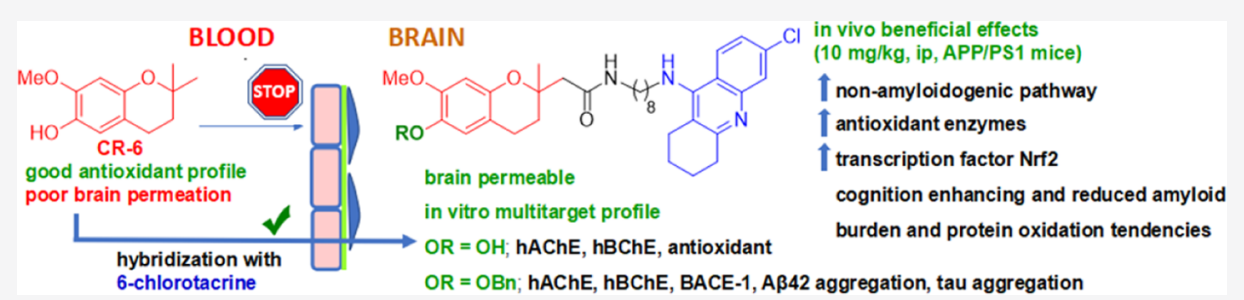

ABSTRACT: Oxidative stress is a major pathogenic factor in Alzheimer's disease, but it should not be tackled alone rather together with other key targets to derive effective treatments. The combination of the scaffold of the polar antioxidant lead 7-methoxy-2,2dimethylchroman-6-ol (CR-6) with that of the lipophilic cholinesterase inhibitor 6-chlorotacrine results in compounds with favorable brain permeability and multiple activities in vitro (acetylcholinesterase, butyrylcholinesterase, $\beta$-site amyloid precursor protein (APP) cleaving enzyme-1 (BACE-1), and A $\beta 42$ and tau aggregation inhibition). In in vivo studies on wild-type and APP/ presenilin 1 (PS1) mice, two selected compounds were well tolerated and led to positive trends, albeit statistically nonsignificant in some cases, on memory performance, amyloid pathology (reduced amyloid burden and potentiated non-amyloidogenic APP processing), and oxidative stress (reduced cortical oxidized proteins and increased antioxidant enzymes superoxide dismutase 2 (SOD2), catalase, glutathione peroxidase 1 (GPX1), and heme oxygenase 1 (Hmox1) and transcription factor nuclear factorerythroid 2-related factor 2 (Nrf2)). These compounds emerge as interesting brain-permeable multitarget compounds, with a potential as anti-Alzheimer agents beyond that of the original lead CR-6.

\section{INTRODUCTION}

Treatment of Alzheimer's disease $(\mathrm{AD})$ remains one of our most urgent unmet medical needs. Indeed, the figures associated with $\mathrm{AD}$ are really worrying. It is the most prevalent chronic neurodegenerative disorder and the main cause of dementia. Currently, some 50 million people worldwide suffer from dementia, with around 35 million having $\mathrm{AD} .{ }^{1}$ This number is estimated to triple to more than 150 million by 2050. The incidence is also reaching alarming proportions, with more than 10 million new cases per year. The huge incidence and prevalence of $\mathrm{AD}$ together with the fact that it is a fatal disease make it the seventh leading cause of death worldwide. However, unlike other major causes of death, $\mathrm{AD}$ cannot be cured, prevented, or even slowed down. Beyond its devastating effects on $\mathrm{AD}$ patients health, this pathology also strongly affects the quality of life of caregivers, who by more than 50\% see how their social life, work, and even health are negatively affected as a consequence of their caring responsibilities. $^{2}$ To further aggravate the situation, the economic burden of $\mathrm{AD}$ is really a major issue for health systems worldwide, with a total estimated cost of around U.S. $\$ 1$ trillion, which is expected to double in just 10 years.

Indeed, the devastating consequences of $\mathrm{AD}$ are due to the lack of effective drugs that can positively impact disease progression. Currently, only four drugs are available for $\mathrm{AD}$ management, namely, the acetylcholinesterase (AChE) inhibitors donepezil, rivastigmine, and galantamine and the glutamate $N$-methyl D-aspartate (NMDA) receptor antagonist memantine, which are used to temporarily alleviate the cognitive and functional symptoms. Very intensive research efforts have been devoted in the past 2 decades to discovering disease-modifying drugs that could halt disease progression, mainly focused on interfering the biology of $\beta$-amyloid (A $\beta$ ) peptide, widely regarded as a key culprit of $A D$. Despite high

Received: March 31, 2020

Published: July 24, 2020 


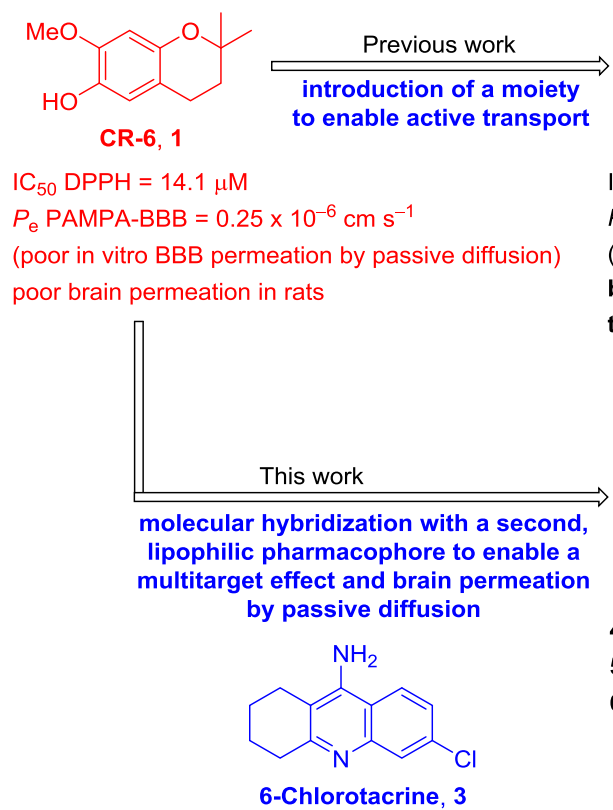

$\mathrm{IC}_{50} \mathrm{hAChE}=14.5 \mathrm{nM} ; \mathrm{IC}_{50} \mathrm{hBChE}=505 \mathrm{nM}$ $P_{\mathrm{e}}$ PAMPA-BBB $=26.1 \times 10^{-6} \mathrm{~cm} \mathrm{~s}^{-1}$

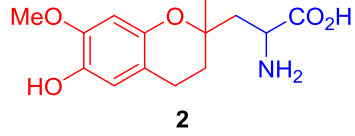

$\mathrm{IC}_{50} \mathrm{DPPH}=14.1 \mu \mathrm{M}$

$P_{\mathrm{e}}$ PAMPA-BBB $=0.04 \times 10^{-6} \mathrm{~cm} \mathrm{~s}^{-1}$

(non-permeable by passive diffusion)

brain permeable in rats by LAT1-mediated active

transport with antioxidant activity

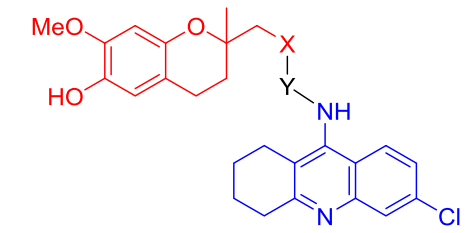

4a-d, $X=\mathrm{CONH}, \mathrm{Y}=\left(\mathrm{CH}_{2}\right)_{7},\left(\mathrm{CH}_{2}\right)_{8},\left(\mathrm{CH}_{2}\right)_{9},\left[\left(\mathrm{CH}_{2}\right)_{2} \mathrm{OCH}_{2}\right]_{2}$

5a-c, $X=\mathrm{CH}_{2} \mathrm{NHCO}, \mathrm{Y}=\left(\mathrm{CH}_{2}\right)_{6},\left(\mathrm{CH}_{2}\right)_{7},\left(\mathrm{CH}_{2}\right)_{8}$

6a-d, $X=\mathrm{CH}_{2} \mathrm{NH}, \mathrm{Y}=\left(\mathrm{CH}_{2}\right)_{7},\left(\mathrm{CH}_{2}\right)_{8},\left(\mathrm{CH}_{2}\right)_{9},\left[\left(\mathrm{CH}_{2}\right)_{2} \mathrm{OCH}_{2}\right]_{2}$

expected brain permeation by passive diffusion with multitarget biological profile

Figure 1. Design strategy of the CR-6-chlorotacrine hybrids.

expectations, all putative disease-modifying drug candidates have disappointingly failed to demonstrate efficacy in advanced clinical trials, which has made $\mathrm{AD}$ drug discovery one of the areas with the highest attrition rate, with a failure rate of $99.6 \%$ since the launching of memantine, so far the last approved drug. ${ }^{1}$ In this scenario, it becomes evident that $\mathrm{AD}$ is a matter of tremendous social concern worldwide, with up to $95 \%$ of people thinking they will develop dementia in their lifetime and $25 \%$ thinking that there is nothing that can be done about it. $^{2}$

To meet the desperate need for effective therapies, alternative ways to approach $\mathrm{AD}$ should be tested. There is a growing awareness that $\mathrm{AD}$ is a complex disorder in which multiple factors concur to the onset of the pathological scenario and that cannot be efficiently cured by modulating a single biological target or pathological event but with combinations of drugs ${ }^{1}$ or with multitarget drugs, i.e., single molecules that are able to hit more than one target with a key role in the pathological network of $\mathrm{AD} .{ }^{3}$ Indeed, simultaneous modulation of several crucial biological targets of $\mathrm{AD}$ is being increasingly accepted as a realistic option to inflict a serious damage to the $\mathrm{AD}$ network and derive effective treatments. ${ }^{4}$ As a result, together with cancer, $\mathrm{AD}$ is the area in which the development of multitarget agents seems to have experienced a greater growth over the last 15 years. ${ }^{5}$

Thus far, a large number of multitarget agents, usually designed by combination of different pharmacophores, have been developed to hit several key biological targets or pathological events of $\mathrm{AD} .{ }^{6}$ Apart from modulating $\mathrm{A} \beta$ biology (inhibition of $\mathrm{A} \beta$ formation by proteolytic cleavage of the amyloid precursor protein (APP) by the $\beta$-site APP cleaving enzyme-1 (BACE-1 or $\beta$-secretase) and $\gamma$-secretase or inhibition of $\mathrm{A} \beta$ aggregation), inhibition of cholinesterases (AChE and butyrylcholinesterase (BChE)) is also commonly considered for the design of multitarget anti-AD agents. ${ }^{7}$

Another crucial pathological event of $\mathrm{AD}$ is oxidative stress. Because of its high demand for oxygen, high levels of peroxidizable lipids (polyunsaturated fatty acids), and deficiency of antioxidant defense systems, brain is highly vulnerable to oxidative stress. ${ }^{8}$ Thus, increased levels of markers of cell component oxidation and altered levels of antioxidant enzymes are found in brains of $\mathrm{AD}$ patients. Indeed, increased levels of protein oxidation markers, such as carbonylated proteins, are found not only in $\mathrm{AD}$ brains but also in patients suffering from amnestic mild cognitive impairment (MCI). The latter finding supports the idea that oxidative stress is involved in the early stages of $\mathrm{AD}$. Additionally, oxidative stress could be necessary for the deployment of other pathological mechanisms of $\mathrm{AD}$, such as $\mathrm{A} \beta$ - and tau-induced neurotoxicity, which makes it a key pathogenic element in $\mathrm{AD}{ }^{9}$ Removal or prevention of the formation of reactive oxygen species (ROS) may, hence, be helpful to halt $\mathrm{AD}$ progression. In this light, antioxidants have been evaluated as a potential treatment of $\mathrm{AD}$ or even MCI. However, results from clinical trials have been disappointing, ${ }^{10}$ with poor brain permeation likely accounting, at least in part, for the lack of clinical efficacy of antioxidants. ${ }^{11}$

This was a major drawback of the so-called 7-methoxy-2,2dimethylchroman-6-ol (CR-6) (1, Figure 1), the most potent antioxidant within a series of chroman derivatives developed by some of us. This compound showed a very interesting in vitro antioxidant profile, including inhibitory effect on lipid peroxidation $^{1 \frac{1}{2}}$ and $\mathrm{NO}$ scavenging activity and protective effect against glutamate-induced neurotoxicity in cultured cerebellar neurons ${ }^{13}$ and against hydrogen peroxide-induced apoptosis in human neuroblastoma SH-SY5Y cells. ${ }^{14}$ The neuroprotective effect of CR-6 has been also demonstrated in an in vivo study, which revealed a reduction of oxidative damage after a cerebral ischemia/reperfusion process in rats. ${ }^{15}$ However, despite the fact that CR-6 was detected in the brain, its concentration was not high enough to elicit the desired neuroprotective effects at the desired level. Indeed, the permeability $\left(P_{\mathrm{e}}\right)$ of CR-6 measured in the parallel artificial membrane permeation assay (PAMPA) for blood-brain 
Scheme 1. Synthesis of the CR-6-(Chloro)tacrine Hybrids 4a-d, 11a-c, 11e, 12a-c, and $12 \mathrm{e}^{a}$

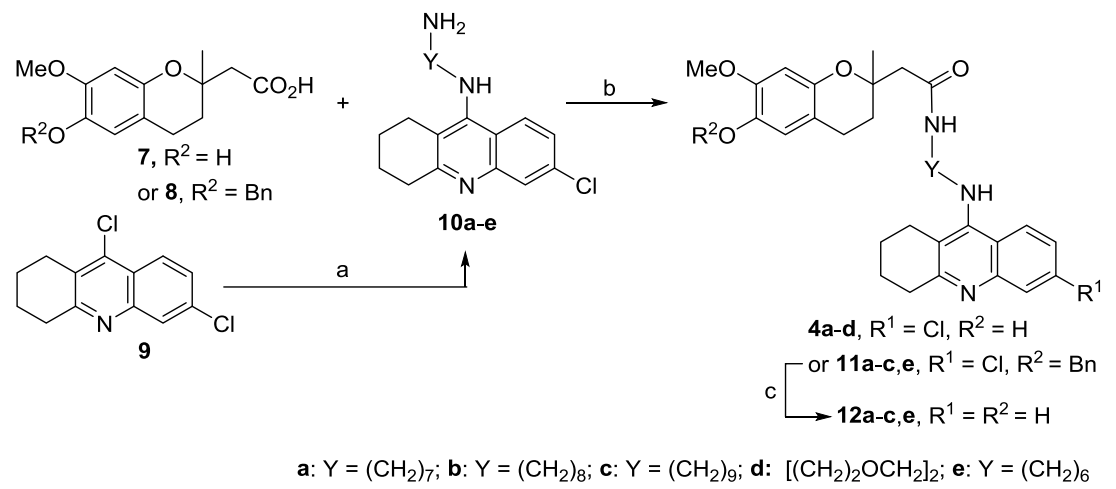

${ }^{a}$ Reagents and conditions: (a) diamine, 1-pentanol, reflux or closed vessel, 18-24 h, 59\% (10a), 69\% (10b), 59\% (10c), 77\% (10d), 32\% (10e); (b) 7 or $8, \mathrm{~N}$-(3-dimethylaminopropyl)- $\mathrm{N}^{\prime}$-ethylcarbodiimide hydrochloride (EDC·HCl), 1-hydroxy-1H-benzotriazole $(\mathrm{HOBt}), \mathrm{Et}_{3} \mathrm{~N}, \mathrm{EtOAc} /$ dimethylformamide (DMF), room temperature (rt), 15 min; then, 10a-e, EtOAc/DMF, rt, 24 h, 67\% (4a), 67\% (4b), 86\% (4c), 91\% (4d), 83\% (11a), 92\% (11b), 90\% (11c), 100\% (11e); (c) H 2 (1 atm), 10\% w/w Pd/C, EtOH, rt, overnight, 72\% (12a), 99\% (12b), 99\% (12c), 99\% (12e).

\section{Scheme 2. Synthesis of the CR-6-Chlorotacrine Hybrids 5a-ca}

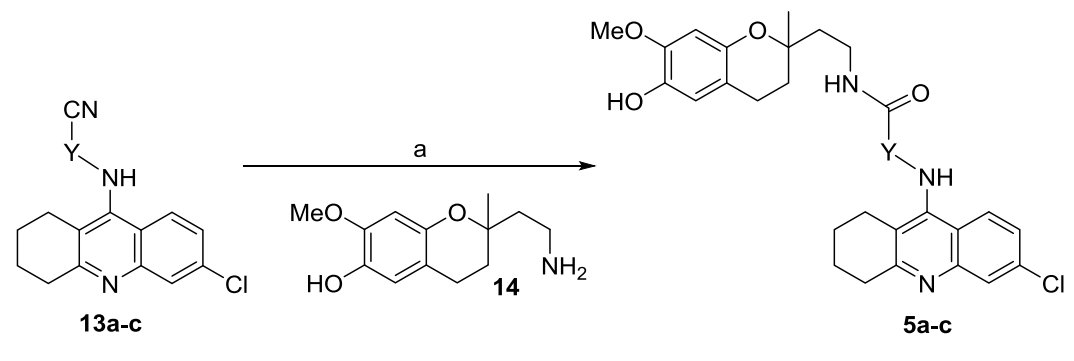

$\mathbf{a}: \mathrm{Y}=\left(\mathrm{CH}_{2}\right)_{6} ; \mathbf{b}: \mathrm{Y}=\left(\mathrm{CH}_{2}\right)_{7} ; \mathbf{c}: \mathrm{Y}=\left(\mathrm{CH}_{2}\right)_{8}$

${ }^{a}$ Reagents and conditions: (a) 13a-c, $40 \%$ methanolic $\mathrm{KOH}$, reflux, $3 \mathrm{~h} ; \mathrm{H}_{2} \mathrm{O}$, reflux, overnight; $\mathrm{HCl}$ in dioxane or $\mathrm{Et}_{2} \mathrm{O}$; resulting carboxylic acid, $\mathrm{EDC} \cdot \mathrm{HCl}, \mathrm{HOBt}, \mathrm{Et}_{3} \mathrm{~N}$, EtOAc/DMF, rt, 15 min; then, 14, EtOAc/DMF, rt, 24 h, 87\% (5a), 55\% (5b), 52\% (5c).

barrier (BBB) had been found to be negligible (Figure 1). As a first attempt to overcome this limitation, the CR-6 scaffold has been recently conjugated with essential brain nutrients such as amino acids or glucose that are recognized by active transport systems (e.g., compound 2, Figure 1). ${ }^{16}$

Apart from the limitation of poor brain permeation of most antioxidants, targeting oxidative stress alone does not seem to be a realistic option to derive a clinically efficacious treatment. ${ }^{9 a}$ The use of antioxidant cocktails or combination of antioxidants with drugs targeting other underlying causes of $\mathrm{AD}$ has been proposed as a more realistic option to cope with the multifactorial nature of $\mathrm{AD} .^{8}$ However, the use of antioxidants in drug combinations would not avoid the brain permeation issues that is inherent to many antioxidants. A very convenient way to conciliate both needs is the design of hybrid compounds in which the antioxidant moiety is attached to a second, more lipophilic, pharmacophore, i.e., the design of lipophilic multitarget compounds featuring an antioxidant moiety, such as melatonin or trolox, among others. ${ }^{17}$

Herein, we describe the synthesis and in vitro and in vivo biological evaluation of a new class of multitarget hybrids that combine the scaffold of the polar non-brain-permeable antioxidant lead CR-6 with 6-chlorotacrine (3, Figure 1), a very potent lipophilic AChE inhibitor, through linkers with different lengths and functionalities. We inferred that the 6chlorotacrine moiety $\left(P_{\mathrm{e}}\right.$ PAMPA-BBB $\left.=26.1 \times 10^{-6} \mathrm{~cm} \mathrm{~s}^{-1}\right)$ should impart brain permeability to the resulting CR-6-based hybrids, as well as a second biological activity (AChE inhibition) of interest for $\mathrm{AD}$ treatment. ${ }^{18}$ Apart from the biological activities resulting from the modulation of the primary targets (antioxidant and anticholinesterase activities), we have quite consistently observed that hybrid compounds bearing two aromatic systems separated by linkers of suitable length are able to inhibit the aggregation of $\mathrm{A} / 42$ and tau, ${ }^{19}$ two key pathogenic actors in $\mathrm{AD}$, as well as other nonrelated amyloidogenic proteins, ${ }^{20}$ thereby expanding their multitarget profile. Additionally, some of these hybrids, featuring a protonatable 6-chlorotacrine (3, Figure 1), tacrine, or a structurally related huprine moiety have been found to inhibit BACE-1, the enzyme that catalyzes the first rate-limiting step of $\mathrm{A} \beta$ formation. ${ }^{19 \mathrm{a}, \mathrm{b}, 21}$ Thus, the novel CR-6-chlorotacrine hybrids reported herein were tested in vitro for their antioxidant effect; their inhibitory activities against human cholinesterases (hAChE and hBChE), A $\beta 42$ and tau aggregation, and human $\mathrm{BACE}-1$; and their brain permeabilities. The in vivo efficacy of two selected compounds was evaluated in APP/presenilin 1 (PS1) mice, a well-established mouse model of $\mathrm{AD}$, in terms of their effect on cognition and markers of oxidative stress and amyloid pathology.

\section{RESULTS AND DISCUSSION}

Design. The presence of a hydroxyl group at position 6 of the chroman scaffold of CR- 6 is the most important structural feature for its antioxidant effects, and, hence, it had to be preserved in the hybrids. In contrast, derivatization of CR-6 by functionalization at position 2 does not affect the antioxidant 
Scheme 3. Synthesis of the CR-6-Chlorotacrine Hybrids $6 a-d^{a}$

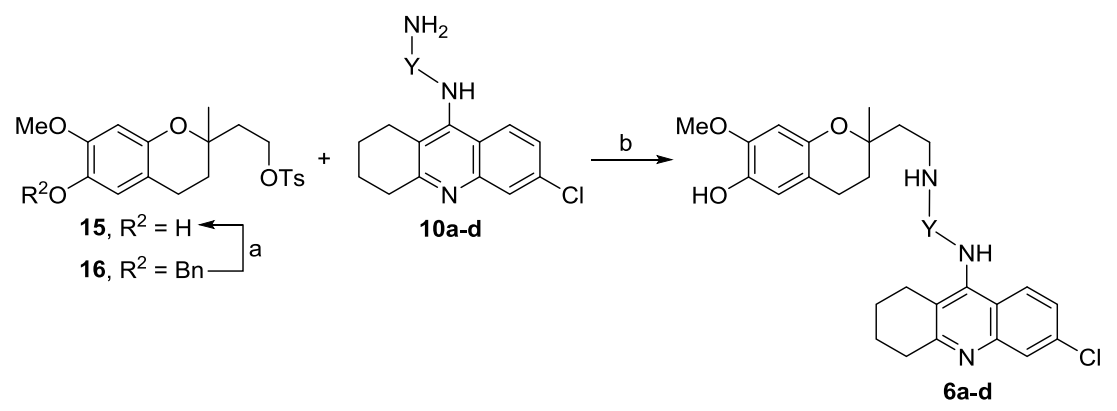

$\mathbf{a}: \mathrm{Y}=\left(\mathrm{CH}_{2}\right)_{7} ; \mathbf{b}: \mathrm{Y}=\left(\mathrm{CH}_{2}\right)_{8} ; \mathbf{c}: \mathrm{Y}=\left(\mathrm{CH}_{2}\right)_{9} ; \mathbf{d}:\left[\left(\mathrm{CH}_{2}\right)_{2} \mathrm{OCH}_{2}\right]_{2}$

${ }^{a}$ Reagents and conditions: (a) $\mathrm{H}_{2}(1 \mathrm{~atm}), 10 \% \mathrm{w} / \mathrm{w} \mathrm{Pd} / \mathrm{C}$, tetrahydrofuran (THF), rt, overnight, $90 \%$; (b) $\mathrm{Et}_{3} \mathrm{~N}, \mathrm{CH}_{3} \mathrm{CN}, 80{ }^{\circ} \mathrm{C}, 48 \mathrm{~h}, 24 \%(6 a)$, $57 \%$ (6b), 59\% (6c), 30\% (6d).

activity. ${ }^{16}$ Indeed, the previously mentioned CR-6 derivative 2, functionalized at this position with an amino acid side chain, is equipotent to the lead CR-6 (Figure 1). Likewise, the CR-6 derivative 7 (Scheme 1), substituted at position 2 of the chroman scaffold with an acetic acid chain, displays an even slightly higher antioxidant effect (half-maximal inhibitory concentration ( $\mathrm{IC}_{50}$ ) 2,2-diphenyl-1-picrylhydrazyl (DPPH) $=8.4 \mu \mathrm{M}) .{ }^{16}$ The carboxylic acid of compound 7 is ideal for the introduction of the linker attached to the 6-chlorotacrine moiety through an amide bond. Thus, compound 7 is selected as the starting material for the synthesis of a first series of CR6-chlorotacrine hybrids featuring an amide functionality within the linker (hybrids $\mathbf{4 a}-\mathbf{d}$, Figure 1 and Scheme 1). The synthesis of two other series of hybrids that featured a reverse amide (hybrids $\mathbf{5 a - c}$, Figure 1 and Scheme 2) or an amine (hybrids $\mathbf{6 a}-\mathbf{d}$, Figure 1 and Scheme 3) within the linker is also envisaged, starting from the CR-6 derivatives 14 and 16, respectively, ${ }^{16}$ to further assess the effect of the linker amide or a protonatable amino group on the interaction with the putative biological targets. We have developed other families of multitarget compounds featuring a chlorotacrine or huprine moiety linked to a second polycyclic pharmacophore through an amide-containing tether chain. These hybrids with a total linker length of 10-12 atoms, from the amino group of chlorotacrine or huprine to the other polycyclic system (counting the atoms of the amide group), are found to display a better overall biological profile including AChE, BACE-1, and/or $A \beta 42$ and tau aggregation inhibition. ${ }^{19 a, c, d}$ On the basis of these premises, our main interest is the synthesis of a parallel series of CR-6-chlorotacrine hybrids with total linker lengths of 10 atoms (4-6a, 11a, 12a), 11 atoms $(4-6 b, 11 b, 12 b)$, and 12 atoms (4-6c, 11c, 12c). Additionally, shorter homologues with a total linker length of nine atoms (11e, 12e) and analogues containing an ethylene glycol group within the linker (4d, 6d), aiming to increase aqueous (aq) solubility, are synthesized for some, but not all, of the series in light of their less favorable biological activities (see below).

Synthesis. Hybrids $\mathbf{4 a}-\mathbf{d}$ were synthesized in racemic form in good yield $(67-91 \%)$ in just one step, by $N$-(3dimethylaminopropyl)- $N^{\prime}$-ethylcarbodiimide hydrochloride (EDC. $\mathrm{HCl}) / 1$-hydroxy-1H-benzotriazole (HOBt)-mediated amide coupling of racemic carboxylic acid $7^{16}$ with the known aminoalkyltacrines $10 \mathbf{a}-\mathrm{c}^{22}$ and $10 \mathrm{~d},{ }^{23}$ which were readily prepared by aromatic nucleophilic substitution of dichloroacridine $\mathbf{9}^{24}$ with commercially available diamines (Scheme 1).
The yield of the latter amide coupling reactions could be still improved when protecting the hydroxyl group at position 6 of the chroman carboxylic acid. Thus, reaction of racemic Obenzylated carboxylic acid $8^{16}$ with amines $10 \mathrm{a}-\mathrm{c}$ and $10 \mathrm{e}^{22}$ in the presence of $\mathrm{EDC} \cdot \mathrm{HCl}$ and $\mathrm{HOBt}$ led to O-benzylated amides $11 a-c$ and 11e in $83 \%$ to quantitative yield. With these amides in hand, we performed a double O-debenzylation/ dechlorination reaction by hydrogenolysis under $\mathrm{Pd} / \mathrm{C}$ catalysis, which afforded in excellent yields a parallel series of hybrids featuring the amide group at the linker and an unsubstituted tacrine unit (hybrids 12a-c and 12e, Scheme 1).

The synthesis of the reverse amide hybrids $\mathbf{5 a - c}$ was accomplished in two steps from the known cyanoalkyltacrines $13 \mathbf{a}-\mathbf{c}^{25}$ Alkaline hydrolysis of nitriles $13 \mathbf{a}-\mathbf{c}$, followed by acidification with a dioxane or $\mathrm{Et}_{2} \mathrm{O}$ solution of $\mathrm{HCl}$, led to the corresponding carboxylic acids, which were isolated in the form of quinoline hydrochloride salts. EDC/HOBt-mediated amide coupling of these crude carboxylic acids with racemic CR-6-derived primary amine $14^{16}$ afforded the target reverse amide hybrids $\mathbf{5 a}-\mathbf{c}$ in racemic form in moderate to good overall yields (52-87\% overall from nitriles $13 a-c$, Scheme 2).

Finally, racemic hybrids $\mathbf{6 a}-\mathbf{d}$ bearing a protonatable aliphatic secondary amine within the linker were synthesized in low to moderate yields (24-59\%) by alkylation of the primary amines $10 a-d^{22}$ with the new CR-6-derived tosylate 15, which, in turn, was readily prepared by hydrogenolysis of its racemic O-benzylated precursor $16^{16}$ (Scheme 3 ).

The CR-6-chlorotacrine hybrids are chiral due to the presence of a stereocenter at position 2 of the chroman moiety. They were prepared and tested in racemic form. We envisaged the resolution of the CR-6-based racemic carboxylic acid 8 . However, different resolution attempts via formation of diastereomeric esters with the enantiopure alcohols $(S)$-3hydroxy-4,4-dimethyl-1-phenylpyrrolidin-2-one ( $(S)$-N-phenylpantolactam $)^{26}$ and $(1 R, 2 S, 5 R)$-2-isopropyl-5-methylcyclohexanol ((-)-menthol), followed by silica gel column chromatography separation, or via diastereomeric salts with (S)-(-)-1-phenyethylamine, followed by recrystallization, were fruitless. Taking into account these results and the fact that no big difference was expected for the enantiomers of the CR-6chlorotacrine hybrids either in their antioxidant effects or in their AChE and BChE inhibitory activities, as predicted by molecular dynamics (MD) simulations (see below), we did not undertake further resolution attempts. 
Table 1. In Vitro Biological Profiling of the Novel CR-6-(Chloro)tacrine Hybrids

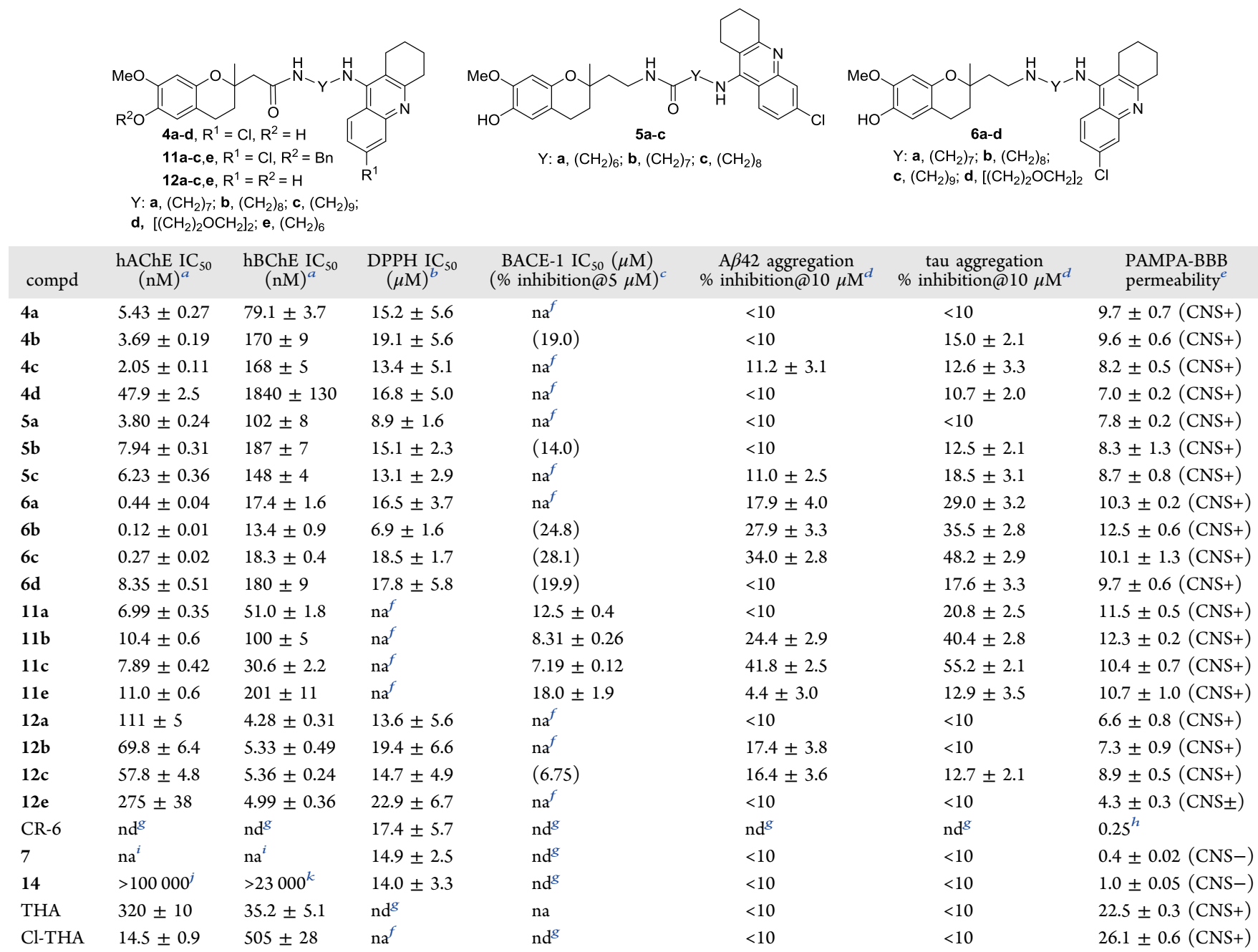

${ }^{a} \mathrm{IC}_{50}$ inhibitory concentration $(\mathrm{nM})$ toward human recombinant $\mathrm{AChE}$ and $\mathrm{BChE}$ from human serum. $\mathrm{IC}_{50}$ values are expressed as mean \pm standard error of the mean (SEM) of at least two experiments, each performed in triplicate. ${ }^{b} \mathrm{IC}_{50}$ inhibitory concentration $(\mu \mathrm{M})$ for DPPH radical scavenging activity. Values are expressed as mean \pm standard deviation $(\mathrm{SD})$ of single experiments performed in triplicate. Trolox $\left(\mathrm{IC}_{50}=15.7 \pm\right.$ $0.9 \mu \mathrm{M})$ was also used as a reference compound. ${ }^{c} \mathrm{IC}_{50}$ inhibitory concentration $(\mu \mathrm{M})$ or \% inhibition of human recombinant BACE-1 at $5 \mu \mathrm{M}$. Values are expressed as mean \pm standard deviation $(\mathrm{SD})$ of two independent experiments, each performed in triplicate. Myricetin $\left(\mathrm{IC}_{50}=3.82 \pm\right.$ $0.87 \mu \mathrm{M})$ was used as a reference compound. ${ }^{d} \%$ inhibition of $\mathrm{A} \beta 42$ and tau protein aggregation at $10 \mu \mathrm{M}$ in intact Escherichia coli cells. Values are expressed as mean \pm SEM of nine independent experiments, each performed in duplicate. DP $128^{20}$ (\% inhibition of A $\beta 42$ and tau aggregation of $68.2 \pm 2.1$ and $72.2 \pm 2.1$, respectively, at $10 \mu \mathrm{M})$ was used as a reference compound. ${ }^{e}$ Permeability values $\left(P_{\mathrm{e}}, 10^{-6} \mathrm{~cm} \mathrm{~s}^{-1}\right)$ from the PAMPABBB assay. Values are expressed as the mean \pm SD of three independent experiments, each performed in triplicate. ${ }^{f}$ Not active. ${ }^{g}$ Not determined. ${ }^{h}$ Value taken from ref $16 .{ }^{i}$ Not active at $100 \mu \mathrm{M} .{ }^{j} \mathrm{IC}_{50}=101 \pm 9 \mu \mathrm{M} .{ }^{k} \mathrm{IC}_{50}=23.2 \pm 1.1 \mu \mathrm{M}$.

Purity of the Compounds. Apart from the target CR-6chlorotacrine hybrids $(\mathbf{4 a}-\mathbf{d}, \mathbf{5 a}-\mathbf{c}$, and $\mathbf{6 a}-\mathbf{d})$ and the CR-6tacrine hybrids $12 \mathrm{a}-\mathrm{c}$ and $12 \mathrm{e}$, we also subjected the $\mathrm{O}$ benzylated CR-6-chlorotacrine hybrids 11a-c and 11e to biological evaluation. Even though the latter compounds should be devoid of antioxidant effect, due to the substitution at the key hydroxyl group of the chroman scaffold, we wanted to assess the effect of this substitution on the rest of biological activities under evaluation. All of these hybrids were transformed into the corresponding hydrochloride or dihydrochloride salts for their chemical characterization and biological profiling. The analytical samples of all of the tested hybrids possessed a purity $>95 \%$, according to NMR spectra with full assignments and high-performance liquid chromatography (HPLC)-UV/high-resolution mass spectrometry (HRMS) measurements (for more details, see the Experimental Section and Supporting Information).

In Vitro hAChE and hBChE Inhibition. The anticholinesterase activity of the new hybrids was evaluated in vitro by the method of Ellman, ${ }^{27}$ using human recombinant AChE (hAChE) and $\mathrm{BChE}$ from human serum (hBChE). The parent 6-chlorotacrine (Cl-THA), tacrine (THA), and CR-6-derived carboxylic acid 7 and amine $\mathbf{1 4}$ were also tested as reference compounds.

All CR-6-chlorotacrine hybrids $(4 a-d, 5 a-c, 6 a-d, 11 a-c$, and 11e) were more potent hAChE inhibitors than the parent Cl-THA $\left(\mathrm{IC}_{50}=14.5 \mathrm{nM}\right)$, with $\mathrm{IC}_{50}$ values in the single-digit nanomolar or subnanomolar range, with the sole exception of 4d, featuring an ethylene glycol-containing linker (Table 1). The order of potencies among the different series was as follows: amines $(6 \mathbf{a}-\mathbf{d})>$ amides $(4 \mathbf{a}-\mathbf{d})>$ reverse amides 

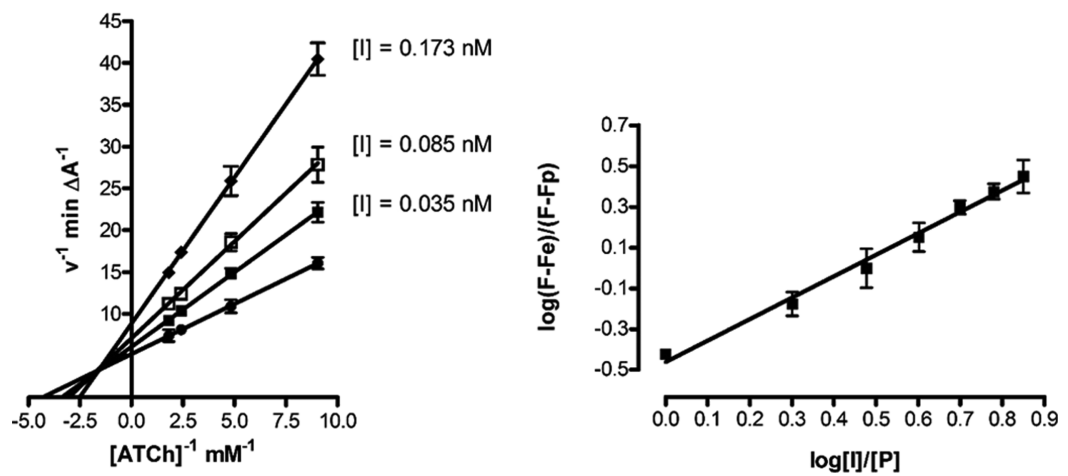

Figure 2. Mechanism of inhibition of hAChE by hybrid $\mathbf{6 b}$. Left, overlaid Lineweaver-Burk reciprocal plots showing the variation of the initial velocity rate $(v)$ as a function of increasing substrate (acetylthiocholine, ATCh) in the absence and presence of increasing concentrations of $6 \mathbf{b}$. The mechanism of inhibition was assessed by two independent experiments, each performed in triplicate. Right, propidium displacement studies to determine the affinity for the PAS of AChE: P and I stand for propidium iodide and inhibitor $(6 \mathbf{b})$, respectively; $F_{\mathrm{e}}$ is the initial fluorescence intensity when enzyme sites are saturated with $\mathrm{P} ; F_{\mathrm{P}}$ is the fluorescence intensity when propidium is completely displaced from the enzyme; and $F$ denotes the fluorescence intensity after adding a determined amount of displacing agent during the titration experiment. Data are the average of three independent experiments.

$(\mathbf{5} \mathbf{a}-\mathbf{c})>$ O-benzylated amides $(11 \mathbf{a}-\mathbf{c}$ and $11 \mathbf{e})$. In the oligomethylene-linked hybrids, all linker lengths were well tolerated, even though, in general, octa- and nona-methylenelinked hybrids were slightly more potent. Conversely, the presence of an ethylene glycol motif within the linker had a clear detrimental effect on hAChE inhibitory activity, with hybrids $4 \mathrm{~d}$ and $6 \mathrm{~d}$ being 13 - and 69-fold less potent than their counterparts $4 \mathrm{~b}$ and $6 \mathrm{~b}$, respectively, which have an equivalent linker length. Overall, the most potent CR-6-chlorotacrine hybrids for hAChE inhibition were the amines $\mathbf{6 a}\left(\mathrm{IC}_{50}=442\right.$ $\mathrm{pM}), \mathbf{6 b}\left(\mathrm{IC}_{50}=121 \mathrm{pM}\right)$, and $6 \mathrm{c}\left(\mathrm{IC}_{50}=272 \mathrm{pM}\right)$, which were 33-, 120-, and 53-fold more potent than the parent $\mathrm{Cl}$ THA, respectively.

Taking into account that the parent CR-6-based carboxylic acid 7 and amine $\mathbf{1 4}$ are essentially inactive or only very weakly active against hAChE, the fact that the vast majority of CR-6chlorotacrine hybrids are more potent than 6-chlorotacrine indicates that the CR- 6 scaffold of the novel hybrids positively contributes to their hAChE inhibitory potency, thereby highlighting the success of the hybridization strategy. It is well known that 6-chlorotacrine interacts at the so-called catalytic anionic site (CAS) of AChE, placed at the bottom of a $20 \AA$ deep gorge. ${ }^{28}$ We anticipated that the higher potency of the novel CR-6-chlorotacrine hybrids might arise from the simultaneous binding to CAS by the 6-chlorotacrine moiety and to a secondary binding site, the peripheral anionic site (PAS), located at the entrance of the catalytic gorge, by the CR-6 scaffold, as found in other families of tacrine-based hybrids. ${ }^{29}$ In the case of hybrids $6 \mathbf{a}-\mathrm{c}$, the presence of a basic aliphatic amino group within the linker, which should be protonated at physiological $\mathrm{pH}$ (and under the conditions of the assay of AChE inhibition), could enable additional interactions with aromatic or anionic midgorge residues, thereby leading to a triple-site binding mode. ${ }^{196,30}$

In 6-chlorotacrine-based hybrids, the chlorine atom, which is accommodated at a hydrophobic pocket within the CAS, greatly contributes to the inhibitory potency. ${ }^{31}$ Thus, quite expectedly, hybrids $12 \mathrm{a}-\mathrm{c}$ and 12e, which feature an unsubstituted tacrine moiety, were 20-30-fold less potent hAChE inhibitors than the 6-chlorotacrine-based counterparts $(\mathbf{4 a}-\mathbf{c})$ but still more potent (up to 5-fold) than tacrine itself $\left(\mathrm{IC}_{50}=320 \mathrm{nM}\right)$, further indicating a beneficial contribution of the CR-6 moiety and of the linker to the inhibitory activity toward hAChE.

Because the levels of $\mathrm{AChE}$ diminish as $\mathrm{AD}$ progresses, hydrolysis of the neurotransmitter acetylcholine is increasingly operated by $\mathrm{BChE}$, which, thereby, is also considered an important target for $\mathrm{AD}$ treatment. ${ }^{32}$ In contrast to the positive effect of the chlorine atom of 6-chlorotacrine on $\mathrm{AChE}$ inhibitory activity, its presence is detrimental for $\mathrm{BChE}$ inhibition, due to steric hindrance effects at the enzyme active site. ${ }^{19 b, 30,33}$ Thus, tacrine $\left(\mathrm{IC}_{50}=35.2 \mathrm{nM}\right)$ is a clearly more potent $\mathrm{hBChE}$ inhibitor than 6-chlorotacrine $\left(\mathrm{IC}_{50}=505 \mathrm{nM}\right)$. Accordingly, the CR-6-chlorotacrine hybrids were found to be less potent inhibitors toward hBChE than hAChE. Notwithstanding the $\mathrm{AChE}$ over $\mathrm{BChE}$ selectivity of these compounds, they still displayed potent $\mathrm{hBChE}$ inhibitory activity, with $\mathrm{IC}_{50}$ values in the two-digit nanomolar range in most cases (Table 1). Indeed, all of them turned out to be more potent $\mathrm{hBChE}$ inhibitors (3-40-fold) than the parent 6-chlorotacrine, with the sole exception of hybrid $\mathbf{4 d}$, bearing an ethylene glycol motif within the linker. Very gratifyingly, some of them $(\mathbf{6 a}-\mathbf{c}$ and 11c) were even slightly more potent $\mathrm{hBChE}$ inhibitors than tacrine, despite the presence of the chlorine atom at their tacrine moiety. Some trends observed for hAChE inhibition were also found for $\mathrm{hBChE}$ inhibition. Thus, the potency within the different series varied in the same order: amines > amides > reverse amides; within a given series, similar potencies were found for the different oligomethylene-linked homologues, and the presence of an ethylene glycol within the linker caused a drop of activity. The only difference was the slightly higher potency of the O-benzylated amides 11 relative to the O-deprotected counterparts 4.

Again, amines 6a $\left(\mathrm{IC}_{50}=17.4 \mathrm{nM}\right), \mathbf{6 b}\left(\mathrm{IC}_{50}=13.4 \mathrm{nM}\right)$, and $6 \mathrm{c}\left(\mathrm{IC}_{50}=18.3 \mathrm{nM}\right)$ were the most potent CR-6chlorotacrine hybrids for $\mathrm{hBChE}$ inhibition, being 29-, 38-, and 28 -fold more potent than the parent 6-chlorotacrine and 2-3fold more potent than tacrine.

Obviously, the hBChE inhibitory activity was even higher in the CR-6-tacrine hybrids $12 a-c$ and 12e, bearing a tacrine instead of a 6-chlorotacrine moiety. These hybrids displayed single-digit nanomolar $\mathrm{hBChE}$ inhibitory potencies, around 5 $\mathrm{nM}$, i.e., potencies approximately 7 -fold higher than that of tacrine. 


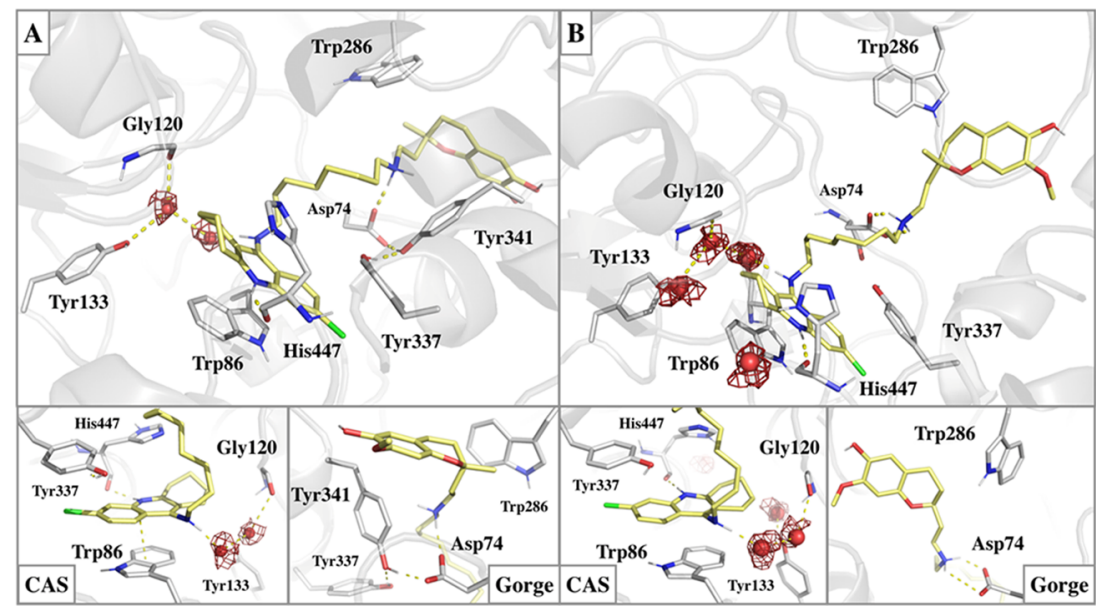

Figure 3. Representative snapshots of the complexes of (A) (R)-6b and (B) (S)-6b bound to hAChE taken from molecular dynamics simulations (started from PDB structure 1Q83). Bottom panels show details of the interactions at the CAS and along the gorge. Density maps for structural water molecules (shown as red spheres) within the catalytic site are depicted as a red isomesh. Selected interactions are shown as yellow dashed lines.

Like for hAChE inhibition, the CR-6-based carboxylic acid 7 was inactive for $\mathrm{hBChE}$ inhibition, whereas the amine 14 displayed only moderate potency $\left(\mathrm{IC}_{50}=23.2 \mu \mathrm{M}\right)$.

All together, these results suggest that introduction of an inactive or weakly active CR-6 moiety adequately linked to the structure of the potent $\mathrm{hAChE}$ and $\mathrm{hBChE}$ inhibitors 6chlorotacrine and tacrine, respectively, significantly increases the anticholinesterase potencies of the resulting hybrids relative to both parent compounds.

The mechanism of inhibition of hAChE by the most potent compound, $\mathbf{6 b}$, was investigated by kinetic and propidium displacement studies and by molecular dynamics simulations. Kinetic studies showed that $\mathbf{6 b}$ acts as a mixed-type inhibitor of hAChE, hence presumably acting as a dual site inhibitor. It displayed an inhibitor dissociation constant $\left(K_{\mathrm{i}}\right)$ of $132 \pm 36$ $\mathrm{pM}$ and a dissociation constant for the enzyme-substrateinhibitor complex $\left(K_{\mathrm{i}}^{\prime}\right)$ equals $258 \pm 2 \mathrm{pM}$ (Figure 2, left). We had inferred that the 6-chlorotacrine moiety of the hybrids should interact at the CAS of AChE, whereas the CR-6 scaffold would be interacting at the PAS. To further confirm the interaction with PAS and estimate the inhibitor's affinity for this site, the ability of $\mathbf{6} \mathbf{b}$ to displace the known PAS ligand propidium was assessed (Figure 2, right). Hybrid $\mathbf{6 b}$ showed a dissociation constant $K_{\mathrm{D}}=2.03 \pm 0.09 \mu \mathrm{M}$, which further confirmed the ability to interact with the PAS of AChE, albeit with a lower affinity than that of the specific PAS ligand propidium $\left(K_{\mathrm{D}}=0.7 \mu \mathrm{M}\right)$.

Finally, the binding mode and mechanism of inhibition of AChE by $\mathbf{6 b}$ and its AChE over BChE selectivity were further studied by molecular dynamics (MD) simulations. In addition, $\mathrm{MD}$ were employed to decipher the molecular features responsible for the high $\mathrm{BChE}$ inhibitory activity of the most potent hybrid, 12a. In these studies, the potential effect of the absolute configuration of the stereocenter at position 2 of the CR-6 moiety was assessed.

The stability of all of the simulated enzyme-ligand complexes was confirmed by the root-mean-square deviation (RMSD) analysis of the residues that define the binding site after the rearrangement of the peripheral site and the concomitant accommodation of the CR- 6 moiety along the AChE gorge (Figure $S 1$ of the Supporting Information). Representative snapshots of $(R)-\mathbf{6 b}$ and $(S)-\mathbf{6 b}$ bound to
AChE derived from MD simulations are shown in Figure 3. Both enantiomers of $\mathbf{6 b}$ exhibit a very similar pattern of interactions except for the chroman moiety, which seems to take slightly different orientations along the gorge according to its stereochemistry. The 6-chlorotacrine moiety is stably stacked against Trp86 and Tyr337 in the CAS (average distances of 3.6 and $4.3 \AA$ from the planes of the chlorotacrine ring to the indole and phenol rings, respectively). The chlorine atom is placed into a small hydrophobic cavity formed by Trp439, Pro446, and Tyr449. The protonated quinoline nitrogen atom of the chlorotacrine moiety is engaged in hydrogen-bonding interactions with the carbonyl oxygen of the catalytic residue His447 (average N...O distance of $2.8 \AA$ ). In addition, a salt bridge between the protonated aliphatic secondary amino group within the linker of $6 \mathbf{b}$ and the carboxylate of Asp74 (average N...O distance of $2.7 \AA$ ) confers stability to the aliphatic linker along the gorge in both enantiomers. This might contribute to stabilize the gorge through a network of interactions reinforced by the salt bridge formed between Asp74 residues with (R)-6b and (S)-6b (Figure 3). These interactions closely resemble those observed for the binding of tacrine-donepezil hybrids to hAChE. ${ }^{34}$ In contrast with the common pattern of interactions observed for the 6-chlorotacrine ring and the tether in the AChE complexes with $(R)-\mathbf{6 b}$ and $(S)-\mathbf{6 b}$, binding of the chroman moiety exhibits slight differences for the two enantiomers. Thus, the CR-6 moiety is located close to Trp286, even though without forming stacking interactions with this latter residue, adopting distinct arrangements in the two complexes. In turn, this suggests that the CR- 6 moiety has a weak contribution to the binding affinity, which may be understood from the larger flexibility of the peripheral site (PAS) compared to the tight packing observed at the CAS, and the solvent exposure of the CR-6 moiety bound to the PAS cavity.

Notwithstanding its higher activity toward hAChE $\left(\mathrm{IC}_{50}=\right.$ $121 \mathrm{pM}$ ), hybrid $6 \mathrm{~b}$ can be definitively considered a very potent $\mathrm{hBChE}$ inhibitor $\left(\mathrm{IC}_{50}=13.4 \mathrm{nM}\right)$. To shed light on the AChE over BChE selectivity of $\mathbf{6} \mathbf{b}$, its binding mode within BChE was also studied by MD simulations. Hybrid $\mathbf{6 b}$ adopts an extended conformation along the gorge of $\mathrm{BChE}$, which resembles the arrangement found in the AChE complex (Figures S2 and S3 of the Supporting Information). The 


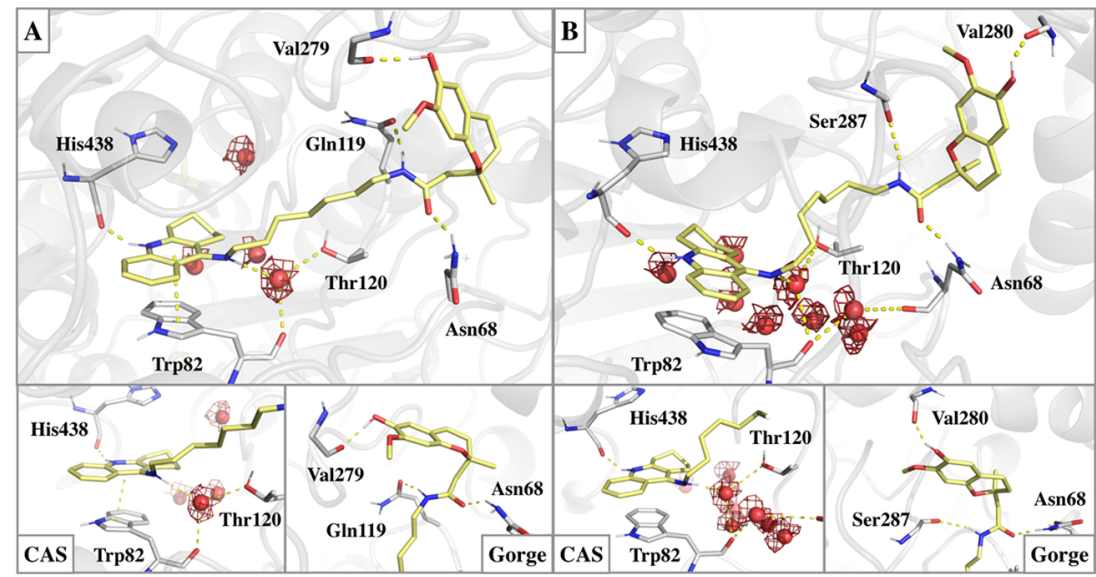

Figure 4. Representative snapshots of the complexes of (A) (R)-12a and (B) (S)-12a bound to hBChE taken from molecular dynamics simulations (started from PDB structure 5K5E). Bottom panels show details of the interactions at the catalytic site and along the gorge. Density maps for structural water molecules (shown as red spheres) within the catalytic site are depicted as a red isomesh. Selected interactions are shown as yellow dashed lines.

structural integrity of the binding mode in the three independent MD simulations is supported by the stability of the RMSD profiles (Figure S2 of the Supporting Information). However, the lower inhibitory activity against $\mathrm{BChE}$ may be attributed to the loss of the hydrophobic subpocket that accommodates the chlorine atom of chlorotacrine due to replacement of Pro446 (in AChE) with Met437 (in BChE), necessary to stabilize the chlorine atom ${ }^{35}$ as well as to the loss of the salt bridge formed between the protonated aliphatic nitrogen and Asp74, thus leading to the AChE over BChE selectivity profile of hybrid $\mathbf{6 b}$.

Finally, MD simulations were also run for both enantiomers of the tacrine-based hybrid $\mathbf{1 2 a}$, which is a selective $\mathrm{BChE}$ inhibitor (Figure 4; RMSD profiles are shown in Figure S4 of the Supporting Information). A similar pattern of interactions was found for both enantiomers, especially regarding the chlorotacrine and tether moieties. The tacrine moiety of 12a is stacked against Trp82 (average distance of $3.5 \AA$ ), with the protonated quinoline nitrogen atom being hydrogen-bonded to the carbonyl oxygen of His438 (average N...O distance of $2.9 \AA$ for both enantiomers). The absence of the chlorine atom at the tacrine moiety prevents the steric clash with Met437, thus contributing to the 3-fold-enhanced BChE inhibitory activity of 12 a relative to $\mathbf{6 b}$. An extensive water-assisted hydrogen-bonding network involving Trp82, Tyr128, Glu197, and the aromatic amine nitrogen enables the stabilization of the protein-ligand complex. At the gorge, the linker amide group acts as a hydrogen-bond acceptor with Asn68 (average $\mathrm{N} \cdots \mathrm{O}$ distances of $3.0 \AA$ for both enantiomers) and as a hydrogen-bond donor with Gln119/Ser287 (average N... distances of 2.8 (Gln119) and 3.5 (Ser287) $\AA$ ) in the $R$ - and $S$ enantiomers, respectively. Finally, the CR-6 moiety of hybrid 12a is located at the PAS and forms transient hydrogenbonding interactions with the main chain of Thr284 and Val279 (Figure 4A) and Val280 (Figure 4B).

Overall, both in vitro studies (kinetic and propidium displacement studies) and MD simulations support a multisite binding mode, with both pharmacophoric moieties and the functional group within the linker (amide or aliphatic amine) contributing to the stabilization of the binding. These multiple interactions account for the high inhibitory potency toward both enzymes.
In Vitro Antioxidant Activity. The in vitro antioxidant activity of the novel hybrids was evaluated by the widely used $\mathrm{DPPH}$ assay, which is based on the ability of antioxidant compounds to donate a hydrogen atom to scavenging the 2,2diphenyl-1-picrylhydrazyl (DPPH) free radical. ${ }^{36}$ Derivatization of the antioxidant lead CR-6 $\left(\mathrm{IC}_{50} \mathrm{DPPH}=17.4 \mu \mathrm{M}\right)$ by introduction of distinct side chains at position 2 is compatible with the retention of the antioxidant activity. ${ }^{16}$ Indeed, the CR6-derived carboxylic acid 7 and amine 14 display the same antioxidant activity as that of the lead $\left(\mathrm{IC}_{50}=14.9\right.$ and 14.0 $\mu \mathrm{M}$, respectively). Likewise, all of the novel CR-6chlorotacrine and CR-6-tacrine hybrids featuring a free hydroxyl group at position 6 of the CR-6 scaffold (4a-d, $5 a-c, 6 a-d, 12 a-c$, and $12 e$ ) retain the antioxidant activity of the parent CR- 6 or are even slightly more potent, with $\mathrm{IC}_{50}$ values in the 6.9-22.9 $\mu \mathrm{M}$ range (Table 1). As expected, hybrids $11 \mathrm{a}-\mathrm{c}$ and $11 \mathrm{e}$, in which this key hydroxyl group is benzylated, were not active in this assay.

Thus, hybridization of the antioxidant lead CR-6 with 6chlorotacrine or tacrine, devoid of antioxidant activity, resulted in compounds that displayed similar antioxidant activity to that of the lead or trolox $\left(\mathrm{IC}_{50}=15.7 \mu \mathrm{M}\right) .^{16}$

In Vitro BACE-1 Inhibition. BACE-1 is the enzyme involved in the first rate-limiting step of the formation of $\mathrm{A} \beta$ by proteolytic cleavage of APP, and, hence, it is also a very important biological target in $\mathrm{AD}$ drug discovery. ${ }^{37}$ Different classes of (chloro)tacrine-based hybrids have been found to be able to inhibit BACE-1 ${ }^{19 b, 38}$ with low micromolar potencies. We have recently found a novel class of hybrids bearing a huprine moiety, structurally related to 6-chlorotacrine, which displayed nanomolar BACE-1 inhibitory activity $\left(\mathrm{IC}_{50}=80\right.$ $\mathrm{nM}){ }^{19 a, 21}$ The 4-aminoquinoline system of the huprine moiety of these hybrids must be mostly protonated at physiological $\mathrm{pH}$ and in the acidic endosomal compartments ( $\mathrm{pH} 4.5-6.5$ ) where BACE-1 localizes. Molecular dynamics simulations have suggested that the protonated huprine moiety may establish a salt bridge with the aspartate residues of the catalytic dyad of BACE-1, whereas the second pharmacophore of these hybrids (the hydroxianthraquinone moiety of rhein) interacts with a transient secondary binding site, located at the edge of the catalytic site, mainly establishing a hydrogen bond between a 
carbonyl group of the hydroxianthraquinone moiety of the hybrid and the guanidinium group of Arg307. ${ }^{21}$

In this light, we screened the novel CR-6-(chloro)tacrine hybrids in vitro against human recombinant BACE-1, using the Panvera substrate. Most of the novel hybrids were found to be inactive or weak BACE-1 inhibitors, with percentages of inhibition below $30 \%$ at an inhibitor concentration of $5 \mu \mathrm{M}$. Only the O-benzylated hybrids 11a-c and 11e displayed moderate inhibitory potency, with $\mathrm{IC}_{50}$ values from 7 to $18 \mu \mathrm{M}$ (Table 1), i.e., in the same range of potency of other (chloro)tacrine-based hybrids but seemingly less potent than the rhein-huprine hybrid. However, it must be mentioned that the assay conditions used to assess the BACE-1 inhibitory activity of these novel hybrids and others previously developed in our group, including the rhein-huprine hybrids, were different. $^{19 a-c}$ Previously, we had used the fluorogenic methoxycoumarin-Ser-Glu-Val-Asn-Leu $\sim$ Asp-Ala-Glu-PheLys-dinitrophenyl (M-2420), which mimics the APP sequence comprising the Swedish mutation, as the substrate. The M2420 substrate is widely used due to its high specificity, predictivity, and quenching efficacy. However, M-2420 is not suitable for the characterization of all types of BACE-1 inhibitors due to its poor selective wavelengths for fluorescence measurements $\left(\lambda_{\mathrm{ex}} / \lambda_{\mathrm{em}} 320 / 420\right)$. Indeed, due to fluorescence interferences of the novel CR-6-chlorotacrine hybrids under those assay conditions, we performed a fluorescence resonance energy transfer (FRET) assay using the Panvera substrate, instead of M-2420. The Panvera substrate is an octapeptide (Glu-Val-Asn-Leu Asp-Ala-Glu-Phe) bearing the Swedish APP mutation. The $k_{\text {cat }} / K_{\mathrm{M}}$ value established for this sequence is 9.5-fold higher than that calculated for M-2420 decapeptide. On the contrary, the entire Panvera substrate is characterized by a reduced rate of substrate cleavage, which implies a longer incubation time than that required for the M-2420 substrate. This can be likely ascribed to some steric hindrance due to the presence of the bulky rhodamine fluorophore and quenching group of the Panvera substrate. Despite the lower predictivity of the assay with the Panvera substrate relative to that of the assay with M-2420, its highly selective wavelengths for fluorescence measurements enable the evaluation of the BACE-1 inhibitory activity for the majority of compounds, even those intrinsically colored. ${ }^{36_{c}}$ By using the new conditions with the Panvera substrate, the $\mathrm{IC}_{50}$ value of the rhein-huprine hybrid was $1.50 \mu \mathrm{M}$. Thus, the novel O-benzylated hybrids $11 \mathrm{a}-\mathrm{c}$ and 11e were still less potent than the rhein-huprine hybrid when using the same assay conditions, with 5-fold lower potencies in the best cases (11b and 11c).

In Cellulo A $\beta 42$ and Tau Antiaggregating Activity. The evaluation of the antiaggregating activity of several classes of (chloro)tacrine- or related huprine-based hybrids developed over the years by our group has shown that many of them display moderate to good potencies, ${ }^{19}$ with percentages of inhibition up to $70-80 \%$ when tested at a $10 \mu \mathrm{M}$ concentration in vitro or in a simplified in vivo model, namely, intact $E$. coli cells that overexpress the amyloidogenic protein, either $\mathrm{A} \beta 42$ or tau. ${ }^{39}$ Interestingly, this antiaggregating activity was extensive to other completely unrelated amyloidogenic proteins associated with other neurologic and non-neurologic disorders and to fungal, yeast, and bacterial proteins. These findings made us hypothesize that common mechanisms exist that mediate the aggregation of amyloidogenic proteins, thereby making the development of amyloid aggregation pan-inhibitors possible. ${ }^{20}$
To further characterize the biological effects of the novel CR-6-(chloro)tacrine hybrids, their A $\beta 42$ and tau antiaggregating activities were assessed in E. coli cells. The series of 6chlorotacrine- and tacrine-based amides and reverse amides were found to be inactive. Similarly, the parent compounds 6chlorotacrine and tacrine and the CR-6-derived carboxylic acid 7 and amine 14 were not active. Moderate antiaggregating potencies were found for the longer homologues of the series of amines (6b and $\mathbf{6 c}$ ) and O-benzylated amides (11b and 11c), with percentages of inhibition around $30-50 \%$ at $10 \mu \mathrm{M}$ (Table 1). Even if these activities were only moderate, they seem to arise from the molecular hybridization because, separately, none of the parent compounds is active in this assay. These results are in line with our hypothesis that hybrid compounds bearing two aromatic systems separated by linkers of suitable length display antiaggregating activity against amyloidogenic proteins, such as $\mathrm{A} \beta 42$ and tau.

In Vitro Brain Permeability. The ability to cross the BBB and enter the brain is a necessary condition for all drugs and candidates developed to treat central nervous system (CNS) diseases, such as $\mathrm{AD}$. Indeed, poor brain permeability seems to be behind the failure of antioxidants in clinical trials against $\mathrm{AD}$, in general, and is one of the major flaws of the antioxidant lead CR-6, in particular. When designing CR-6-based multitarget compounds, we had anticipated that its hybridization with the lipophilic AChE inhibitor 6-chlorotacrine should result in sufficiently increased lipophilicity to make the hybrids brain-permeable through passive diffusion. To validate our hypothesis and assess the suitability of the novel CR-6chlorotacrine hybrids as potential anti-Alzheimer agents, their brain permeability was evaluated using the well-established PAMPA-BBB assay. ${ }^{40}$ The permeability $\left(P_{\mathrm{e}}\right)$ of the novel hybrids, the parent compounds 6-chlorotacrine and tacrine, the CR-6-derived carboxylic acid 7 and amine 14, and 14 commercial drugs, used for assay validation, was measured through a lipid extract of porcine brain membrane. Based on the linear correlation between the reported and experimentally determined $P_{\mathrm{e}}$ values of the commercial drugs and the limits established by $\mathrm{Di}$ et al. for $\mathrm{BBB}$ permeation, ${ }^{40}$ the threshold for high $\mathrm{BBB}$ permeation (CNS+) was set at $P_{\mathrm{e}}\left(10^{-6} \mathrm{~cm} \mathrm{~s}^{-1}\right)>$ 5.2, whereas low BBB permeation (CNS-) was expected for compounds with $P_{\mathrm{e}}\left(10^{-6} \mathrm{~cm} \mathrm{~s}^{-1}\right)<2.0$.

Gratifyingly, all of the novel CR-6-chlorotacrine hybrids displayed PAMPA-BBB permeabilities well over the threshold for high permeation and between the $P_{\mathrm{e}}$ values of the parent polar CR-6-based intermediates 7 and $14\left[P_{\mathrm{e}}\left(10^{-6} \mathrm{~cm} \mathrm{~s}^{-1}\right)=\right.$ 0.4 and 1.0, respectively, both CNS- $]$ and those of the lipophilic 6-chlorotacrine and tacrine $\left[P_{\mathrm{e}}\left(10^{-6} \mathrm{~cm} \mathrm{~s}^{-1}\right)=26.1\right.$ and 22.5 , respectively, both CNS +$]$. Thus, $P_{\mathrm{e}}\left(10^{-6} \mathrm{~cm} \mathrm{~s}^{-1}\right)$ values in the range 7.0-12.5 were found for 6-chlorotacrinebased hybrids $(\mathbf{4 a}-\mathbf{d}, \mathbf{5 a}-\mathbf{c}, \mathbf{6 a}-\mathbf{d}$, and O-benzylated hybrids $11 \mathrm{a}-\mathrm{c}$ and $11 \mathrm{e})$ and in the range 6.6-8.9 for tacrine-based hybrids $(12 \mathrm{a}-\mathrm{c})$. Only the shorter homologue of the tacrinebased series, 12e, showed an uncertain brain permeability (CNS \pm ) with a $P_{\mathrm{e}}$ value slightly lower than that of the CNS+ threshold. Overall, these results suggested that molecular hybridization of CR-6 and 6-chlorotacrine resulted in brainpermeable compounds.

In Vivo Studies: Selection of Compounds. The antioxidant lead CR-6 had been found to exert, at some extent, neuroprotective effects in in vivo studies, despite its poor brain permeation. ${ }^{15}$ After having assessed in vitro the success of the hybridization strategy of CR-6 with 6- 


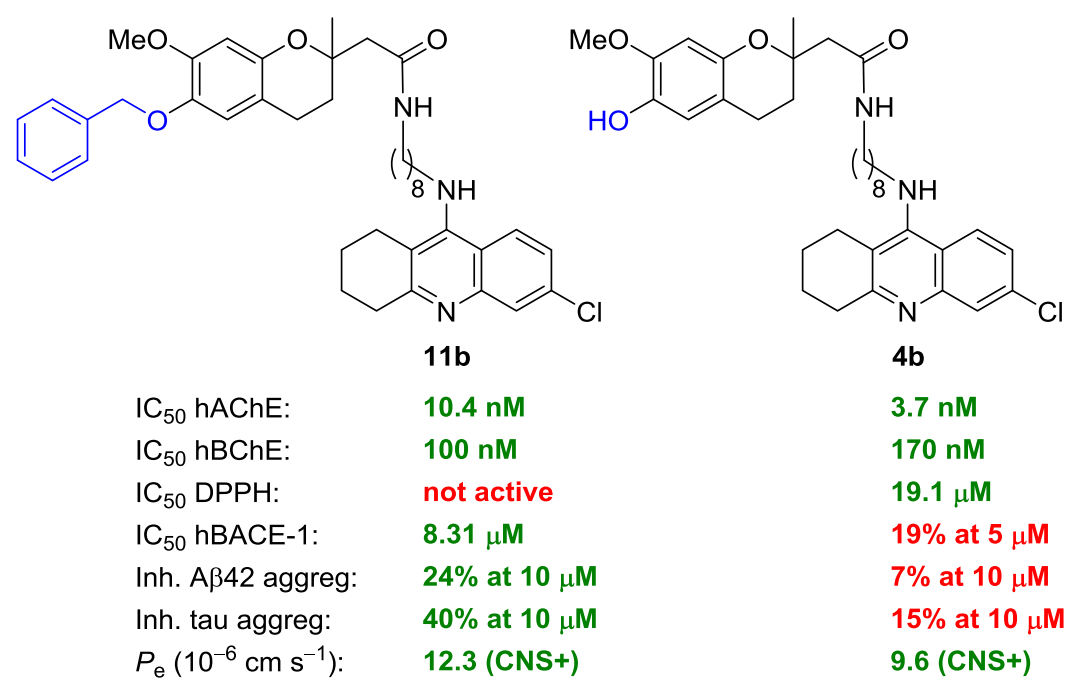

Figure 5. In vitro biological profile of the selected compounds for in vivo efficacy studies.

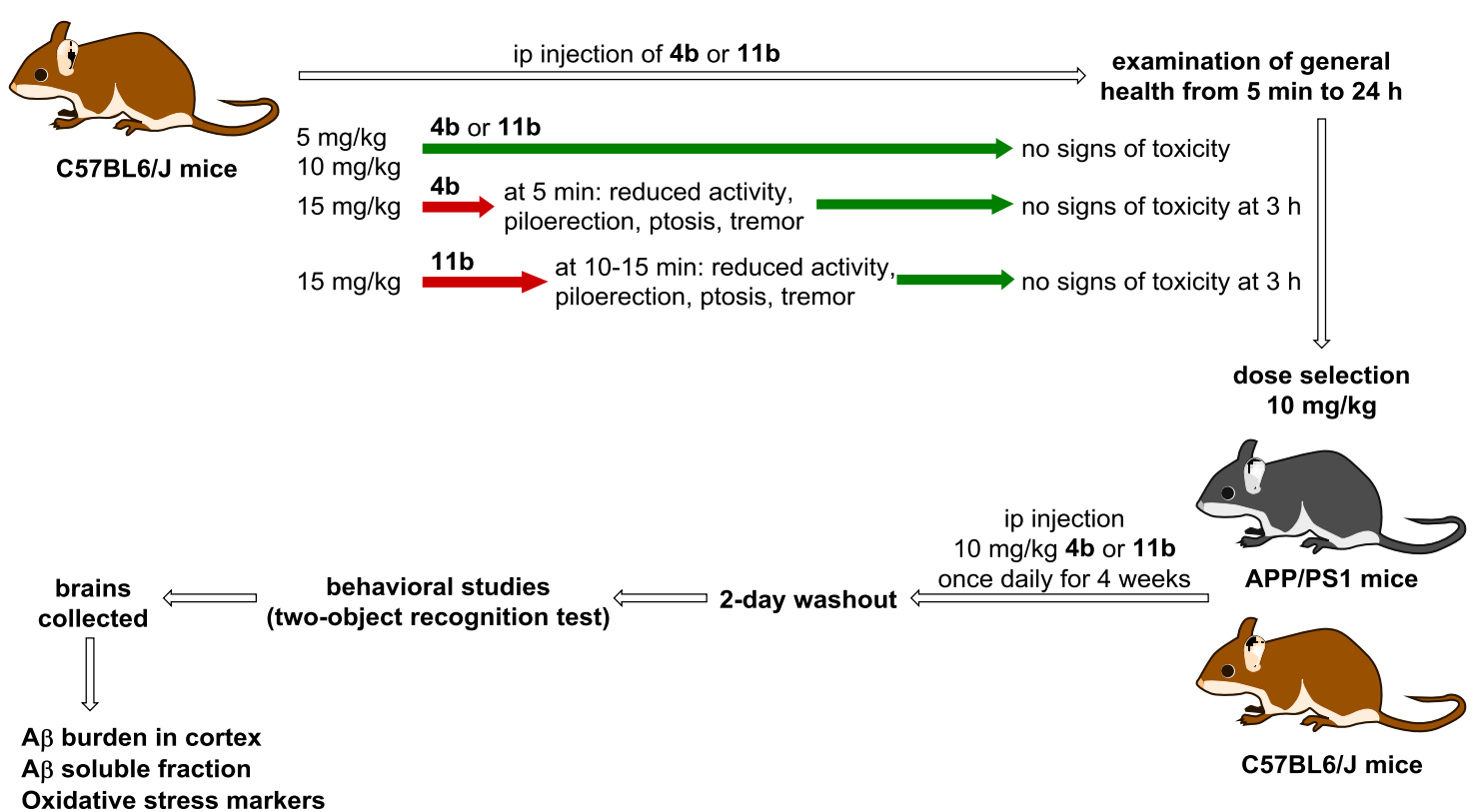

Figure 6. Flow diagram of in vivo efficacy studies with the novel CR-6-chlorotacrine hybrids $\mathbf{4 b}$ and $\mathbf{1 1}$.

chlorotacrine, in terms of both multitarget profile and brain permeation, we decided to further advance to in vivo efficacy studies with selected compounds. Of the 19 novel CR-6(chloro)tacrine hybrids, several compounds displayed an interesting in vitro multitarget profile and could be suitably selected for the in vivo studies. Indeed, many of the compounds displayed very potent hAChE and hBChE inhibitory activities and retained the antioxidant potency of the lead CR-6. This was certainly the case of amines $6 a-c$, which were overall the most potent anticholinesterase compounds, with $\mathrm{IC}_{50}$ values in the subnanomolar range for hAChE inhibition (0.12-0.44 $\mathrm{nM}$ ) and low nanomolar range for hBChE inhibition (13.4-18.3 nM). However, these effects were largely disbalanced with their other activities, namely, antioxidant, BACE-1 inhibition, and antiaggregating potencies in the micromolar range. This might render difficult the selection of a proper dose for in vivo studies that could lead to antioxidant or anti-amyloid effects without the risk of cholinergic side effects. In contrast, the O-benzylated compounds $11 \mathrm{a}-\mathrm{c}$ were devoid of antioxidant activity but endowed with the best BACE- 1 and $\mathrm{A} \beta 42$ and tau antiaggregating activities. Even if in the micromolar range, these activities were not so markedly disbalanced with their one- to two-digit nanomolar anticholinesterase potencies as they were in amines $6 \mathbf{a}-\mathbf{c}$. Moreover, we speculated on the possibility that the O-benzylated hybrids $\mathbf{1 1}$ could be metabolically transformed, at least in part, into the Odebenzylated compounds, i.e., the corresponding hybrids of the amide series 4, through a CYP-mediated O-dealkylation. This is a conceivable metabolic process as it would involve a benzylic position that, per se, is prone to CYP-mediated oxidation. This metabolic conversion would restore the free hydroxyl group at position 6 of the chroman scaffold. Thus, the generated metabolite would be able to exert antioxidant effects.

In light of these considerations and also taking into consideration that they have the same total linker length and very similar anticholinesterase and antiaggregating potencies as those of the so far in vivo best-performing huprine-based 
multitarget compound developed by our group, ${ }^{19 a}$ we selected hybrid $\mathbf{1 1 b}$ and its O-debenzylated counterpart, $\mathbf{4 b}$, to be further advanced to in vivo efficacy studies. Each of these compounds displayed an interesting and distinct complementary mutitarget profile: $\mathbf{4} \mathbf{b}$ displayed the initially pursued anticholinesterase/antioxidant/brain-permeable profile, while 11b was devoid of antioxidant effect but exhibited additional moderate $\mathrm{BACE}-1$ and $\mathrm{A} \beta 42$ and tau antiaggregating effects (Figure 5).

In Vivo Assessment of Acute Toxicity and Dose Selection. The in vivo studies were performed as depicted in Figure 6. First, a preliminary assessment of acute toxicity was carried out for the selection of the dose to be used in the chronic efficacy studies. For this purpose, three doses $(5,10$, and $15 \mathrm{mg} / \mathrm{kg}$ ) of the selected hybrids $4 \mathbf{b}$ and $11 \mathbf{b}$ were injected intraperitoneally (ip) to wild-type (WT) C57BL6/J mice, and their general health status based on the appearance of physical signs was monitored from $5 \mathrm{~min}$ to $24 \mathrm{~h}$ after injection (time points: $5 \mathrm{~min}, 10 \mathrm{~min}, 15 \mathrm{~min}, 30 \mathrm{~min}, 1 \mathrm{~h}, 2 \mathrm{~h}$, $3 \mathrm{~h}, 6 \mathrm{~h}, 8 \mathrm{~h}, 24 \mathrm{~h}$ ). The doses of 5 and $10 \mathrm{mg} / \mathrm{kg}$ of both hybrids were well tolerated. After ip injection of the highest dose of $15 \mathrm{mg} / \mathrm{kg}$ of $\mathbf{4 b}$, some side effects appeared, with the animals showing reduced locomotor activity, piloerection, ptosis, and tremor. All of these effects started disappearing 30 min later, and $3 \mathrm{~h}$ after administration, the animals were normally active, without any physical sign of unhealthy status. The highest dose of $15 \mathrm{mg} / \mathrm{kg}$ of the O-benzylated hybrid $\mathbf{1 1 b}$ produced the same side effects but delayed in time, as they appeared $10-15 \mathrm{~min}$ after ip injection. Like with $\mathbf{4 b}$, the animals looked completely normal $3 \mathrm{~h}$ after the administration of $\mathbf{1 1 b}$. The delayed appearance of the same side effects could be related to the speculated metabolic conversion of $\mathbf{1 1 b}$ into $\mathbf{4 b}$, which might be responsible for the transient side effects, with the delay of their appearance resulting from the time needed for the metabolic debenzylation process.

Chronic In Vivo Efficacy Studies: Behavioral Studies. The in vivo proof of concept for the novel class of CR-6-based hybrids was performed using double-transgenic APP/PS1 mice, a well-established mouse model of $\mathrm{AD}$. The main purpose of these studies was to determine whether the multiple activities found in vitro for the novel hybrids would impact the progression of the neurodegenerative process in vivo, i.e., to assess potential disease-modifying effects. To this end, 6month-old WT and transgenic mice were daily administered with vehicle, $\mathbf{4 b}(10 \mathrm{mg} / \mathrm{kg}$, ip) or $\mathbf{1 1 b}(10 \mathrm{mg} / \mathrm{kg}$, ip), for 4 weeks. Following the chronic treatment, a 2-day washout period was applied, ${ }^{41}$ before animals' cognitive performance evaluation.

To assess the effects of $4 b$ and $\mathbf{1 1 b}$ on cognitive performance, the two-object recognition test was used. One day after letting mice explore for 9 min a $\mathrm{V}$-maze with two identical objects situated at the ends of the arms, one of the two familiar objects was replaced by a novel one and the mice were placed again for $9 \mathrm{~min}$ in the $\mathrm{V}$-maze. The time spent exploring both objects was recorded to calculate an object recognition index (RI) as the difference between the time spent exploring the novel and the familiar object divided by the total time spent exploring the two objects. Low object RI values are indicative of memory impairment. Two-way analysis of variance (ANOVA) revealed a genotype effect $\left(F_{(1,24)}=\right.$ $8.241, p<0.01)$ but no treatment effect or interaction between both factors. Subsequent post hoc analysis indicated a significant memory impairment in vehicle-treated APP/PS1 mice $(p<0.05$, Figure 7$)$ when compared to corresponding WT littermates, but not in hybrid $\mathbf{4 b}$ - and $\mathbf{1 1 b}$-treated APP/

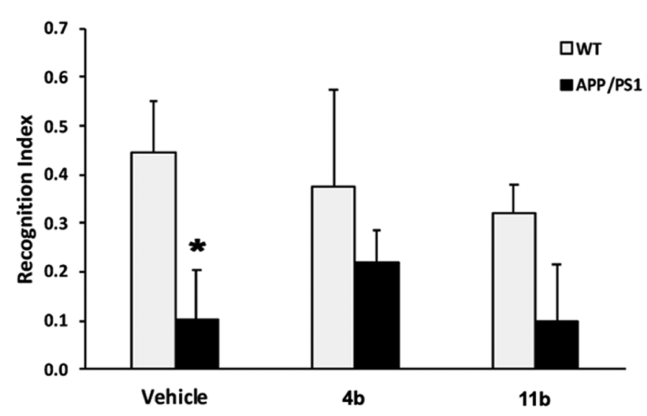

Figure 7. Memory performance in the two-object recognition test of male wild-type (WT vehicle, $n=6$; WT $4 \mathbf{b}, n=5$; WT $11 \mathbf{b}, n=6$ ) and male APP/PS1 mice (APP/PS1 vehicle, $n=5$; APP/PS1 $4 \mathbf{b}, n=$ 7; APP/PS1 11b, $n=6$ ) after chronic treatment with the novel hybrids $\mathbf{4 b}$ and $\mathbf{1 1 b}(10 \mathrm{mg} /(\mathrm{kg}$ day), 4 weeks, ip). APP/PS1 mice chronically treated with vehicle, but not with $\mathbf{4 b}$ or $\mathbf{1 1 b}$, exhibit a significant reduction in the recognition index when compared to corresponding WT littermates. Data are expressed as the mean values \pm SEM. Data were analyzed by two-way ANOVA with genotype ( $p<$ 0.01 ) and treatment as between factors, followed by two-tailed Student's $t$-test to compare between genotypes $(* p<0.05)$.

PS1 mice. Indeed, $\mathbf{4 b}$ - and $\mathbf{1 1} \mathbf{b}$-treated APP/PS1 mice did not worsen their cognitive performance compared to treated WT littermates. Notably, although not statistically significant, hybrid $\mathbf{4 b}$ showed a tendency to increase the RI in APP/PS1 relative to vehicle-treated mice, which might suggest cognitive enhancing properties of this compound (Figure 7).

Effects on Cortical APP/PS1 Mouse Amyloid Pathology. APP/PS1 mice already present amyloid plaques at the age of 6 months. ${ }^{42}$ The effects of treatment with hybrids $4 \mathbf{b}$ and $11 \mathrm{~b}$ on the amyloidogenic and non-amyloidogenic pathways were assessed. To this end, once the behavioral experiments were completed, the animals were sacrificed and their brains were collected and processed for the quantification of several markers of amyloid pathology, namely, cortical amyloid burden and cortical soluble $\mathrm{A} \beta 40$ and $\mathrm{A} \beta 42$ levels. The gene expression of Adam10 ( $\alpha$-secretase) and Bace1 ( $\beta$ secretase) and brain levels of ADAM10, BACE-1, $\operatorname{sAPP} \alpha$ (a product resulting from APP cleavage by $\alpha$-secretase, nonamyloidogenic pathway), and $\operatorname{SAPP} \beta$ (a product resulting from APP cleavage by $\beta$-secretase, amyloidogenic pathway) were also quantified.

First, the analysis of $\mathrm{A} \beta$ burden in the cortex of APP/PS1 mice treated with the novel hybrids, especially $4 \mathrm{~b}$, indicated a tendency to decrease the $\mathrm{A} \beta$ content, although one-way ANOVA revealed that the changes were not statistically significant (Figure 8A,B). Similarly, no significant difference was observed between vehicle and $4 \mathbf{b}$ - or $11 \mathbf{b}$-treated APP/ PS1 mice in the cortical soluble $A \beta 40$ or $A \beta 42$ levels, two of the most toxic forms of $\mathrm{A} \beta$ peptide (Figure $8 \mathrm{C}$ ).

Next, while evaluation of Adam 10 in vehicle-treated animals revealed a reduction in APP/PS1 when compared with WT littermate mice, Bace1 gene expression was higher in APP/PS1 mice (Figure 9A,B). These results agreed with the expected preponderance of the amyloidogenic pathway of APP processing in APP/PS1 transgenic mice, leading to amyloid pathology. However, when evaluating the corresponding protein levels (ADAM10 and BACE-1), we could observe only a tendency, which not fully confirmed gene expression 
A
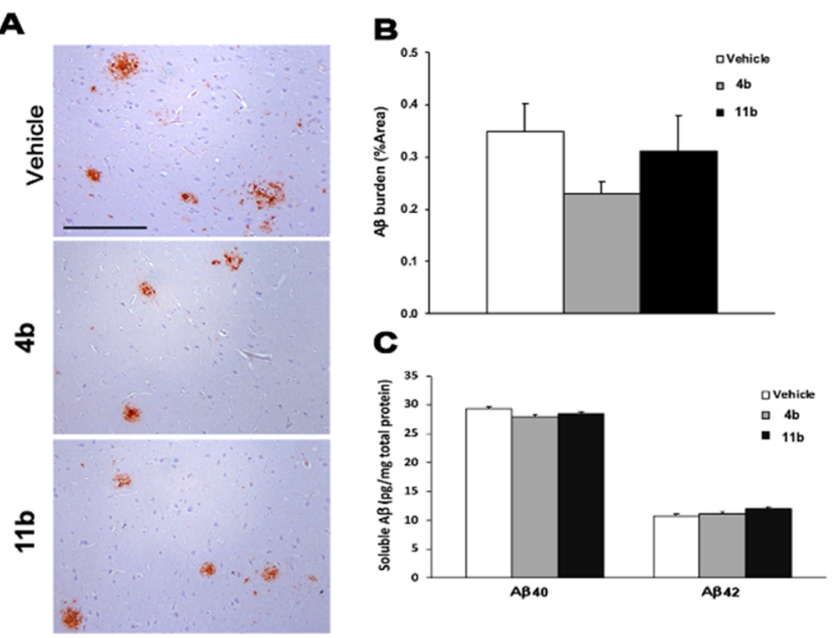

Figure 8. (A) Representative images of $\mathrm{A} \beta$ immunoreactivity in cortical sections of male APP/PS1 mice subjected to chronic vehicle $(n=5), \mathbf{4 b}(n=7)$, or $\mathbf{1} \mathbf{b} \mathbf{b}(n=6)$ treatment. The scale bar represents $200 \mu \mathrm{m}$. (B) A $\beta$ burden quantification reveals a tendency to decrease in the cortex of $\mathbf{4 b} \mathbf{b}$-treated APP/PS1 mice. (C) Soluble $\mathrm{A} \beta_{40}$ and $\mathrm{A} \beta_{42}$ levels are not significantly modified by chronic $4 \mathrm{~b}$ or $11 \mathrm{~b}$ treatment in cortical homogenates of APP/PS1 mice. Data are expressed as the mean values \pm SEM and were analyzed by one-way ANOVA with treatment as between factors (not significant in any case).

results (Figure 9C,D). In $\mathbf{1 1 b}$-treated APP/PS1 mice, a significant increase of gene expression of Adam 10 was found, whereas in $\mathbf{4 b}$-treated mice, the increase was not statistically significant. In contrast, both compounds were found to be able to significantly reduce Bacel gene expression (Figure 9A,B). However, these promising results regarding gene expression of Adam10 (increased by hybrids $\mathbf{4 b}$ and $\mathbf{1 1 b}$ ) and Bace1 (decreased by $\mathbf{4 b}$ and $\mathbf{1 1 b}$ ) did not correlate with the brain levels of the corresponding proteins ADAM10 and BACE-1, except in the case of hybrid $\mathbf{1 1} \mathbf{b}$, which also led to increased protein levels of ADAM10 (Figure 9C,D). Overall, these results could be indicative that hybrids $4 \mathrm{~b}$ and $11 \mathrm{~b}$ might impinge into ADAM10 and BACE-1 expression processes (i.e., post-transcriptional, translational, and protein degradation regulation) controlling steady-state protein abundances, thus making it difficult to establish any correlation between mRNA expression and protein density, as suggested for some perturbed systems. ${ }^{43}$

Finally, regarding the soluble fragments arising from APP cleavage via $\alpha$-secretase (non-amyloidogenic pathway, $\operatorname{sAPP} \alpha$ ) or via BACE-1 (amyloidogenic pathway, sAPP $\beta$ ), nonsignificant differences were found among groups, except for $1 \mathbf{1 b}$, which significantly reduced $\operatorname{sAPP} \beta$ protein levels in WT and APP/PS1 relative to vehicle-treated animals (Figure 9E,F). Collectively, these results might point to a possible beneficial effect of $\mathbf{4 b}$ and $\mathbf{1 1} \mathbf{b}$ pushing up the non-amyloidogenic pathway, thus overcoming the deleterious effects of the amyloidogenic one.

Effects on Oxidative Stress Markers in the Cortex of APP/PS1 Mice. Antioxidants can exert their effects in vivo by directly preventing the formation or scavenging radicals and oxidant species and by upregulating the expression of antioxidant enzymes or inhibiting pro-oxidant enzymes.9a Several of these markers of oxidative stress were evaluated in cortical samples of treated mice. Increased levels of markers of protein oxidation, such as protein carbonyls, are found in brains of $\mathrm{AD}$ and MCI patients. The level of carbonylated proteins generated by oxidative reactions was measured. Twoway ANOVA revealed a genotype effect $\left(F_{(1,24)}=3.784, p<\right.$ $0.05)$, with APP/PS1 mice having clearly higher levels of oxidized proteins in the cortex than WT littermates (Figure 10). The treatment of transgenic mice with the novel hybrids $\mathbf{4 b}$ and $\mathbf{1 1 b}$ led to a tendency to reduce the levels of oxidized proteins compared with the vehicle-treated group, but the decrease was not statistically significant (Figure 10).

The enzyme superoxide dismutase 2 (SOD2) is involved in scavenging ROS produced by the mitochondrial electron transport chain, which are markedly overproduced in the surrounding $\mathrm{A} \beta$ deposition areas. ${ }^{44}$ The levels of SOD2 around $\mathrm{A} \beta$ plaques were analyzed by double immunostaining in brain tissue of APP/PS1 mice. A tendency to increase the levels of the antioxidative enzyme SOD2 was found in $11 \mathbf{b}$-treated animals, even though it did not reach statistical significance (Figure 11).

Despite the lack of statistical significance, we observed a tendency to decrease oxidized proteins in both $4 \mathbf{b}$ - and $11 \mathbf{b}$ treated APP/PS1 mice and to increase the antioxidant enzyme SOD2 after treatment with $\mathbf{1 1 b}$. The nuclear factor-erythroid 2-related factor $2(\mathrm{Nrf2})$ is an emerging regulator of cellular oxidative stress as it controls the expression of an array of antioxidant genes, such as heme oxygenase 1 (Hmoxl) and several genes related to glutathione production and regeneration, among others. To shed light into the mechanisms behind the in vivo antioxidant effects of the novel hybrids, Nrf2 protein levels in the cortex of treated animals were determined (Figure 12A). Interestingly, the treatment with hybrid $\mathbf{1 1 b}$ led to significantly increased total levels of the transcription factor Nrf2 in APP/PS1 mice. The enzymes catalase and glutathione peroxidase 1 (GPX1) are also part of the protective antioxidant system. The levels of the antioxidant enzyme catalase increased after treatment with both $\mathbf{4 b}$ and $\mathbf{1 1} \mathbf{b}$, although it did not reach significance (Figure 12B), whereas GPX1 protein levels were significantly increased in $\mathbf{4 b}$-treated APP/PS1 mice (Figure 12C). Moreover, gene expression for inducible nitric oxide synthase (iNOS) and Hmoxl was evaluated. iNOS gene expression was not modified with treatments, but Hmoxl expression was significantly increased in $\mathbf{4 b}$-treated animals (Figure 12D,E).

While nonsignificant positive tendencies were found for several oxidative stress markers in treated APP/PS1 mice, compound $4 \mathrm{~b}$ did significantly increase GPX1 protein levels and Hmoxl expression, whereas $\mathbf{1 1} \mathbf{b}$ treatment led to a significant increase of Nrf2 protein levels. These results might suggest that $\mathbf{4 b}$ and $\mathbf{1 1 b}$ exert antioxidant effects in vivo either directly increasing detoxifying enzymes against redox misbalance or inducing a slow antioxidant response by modulation of the Nrf2 pathway.

Plasma and Microsomal Stability Studies and Metabolite Identification. Metabolism of drugs, while increasing their polarity to speed clearance from the organism, can lead to active metabolites that contribute to the final biological effect or to reactive metabolites that can cause harmful effects. The latter seems to be the case for tacrine, the first drug approved for the treatment of $\mathrm{AD}$, which was withdrawn from the market due to induction of hepatotoxicity in $30 \%$ of patients. Its toxic effect seems to be largely dependent on the formation of toxic metabolites. Indeed, some metabolites arising from microsomal hydroxylation at positions 
A

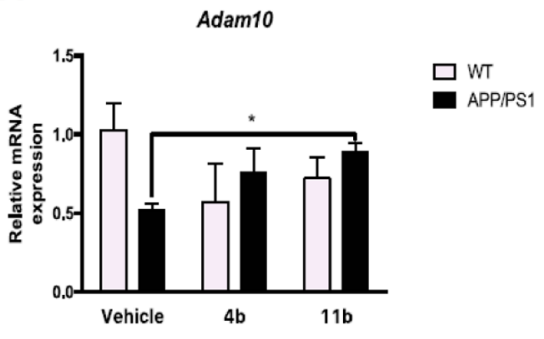

C

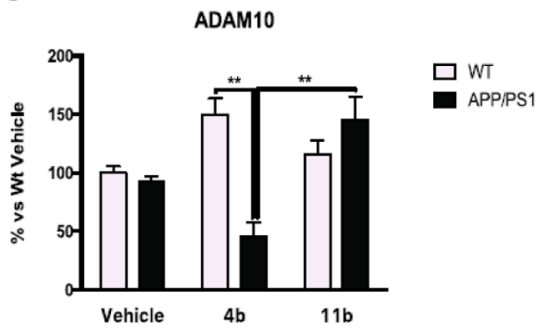

WT APPIPS1 WT APPIPS1 WT APP/PS1 Veh Veh 4b 4b 11b 11b

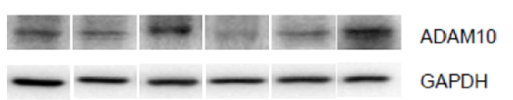

E

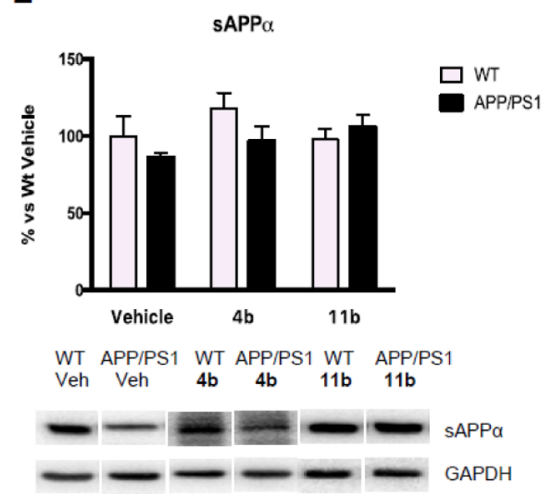

B

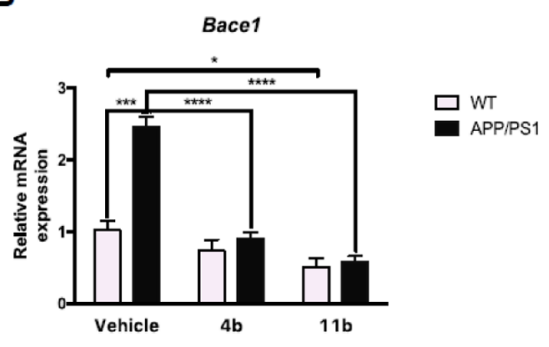

D
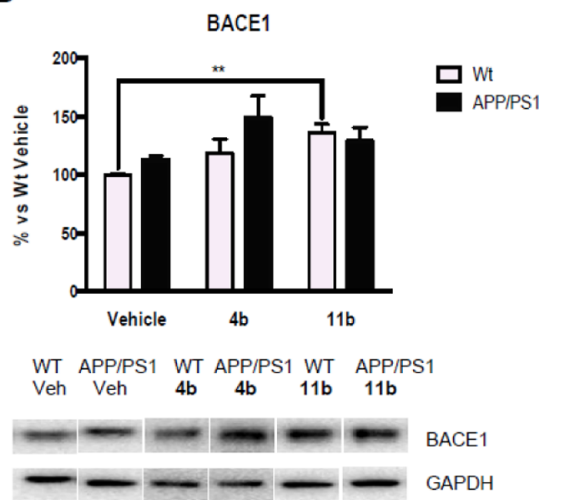

$\mathbf{F}$

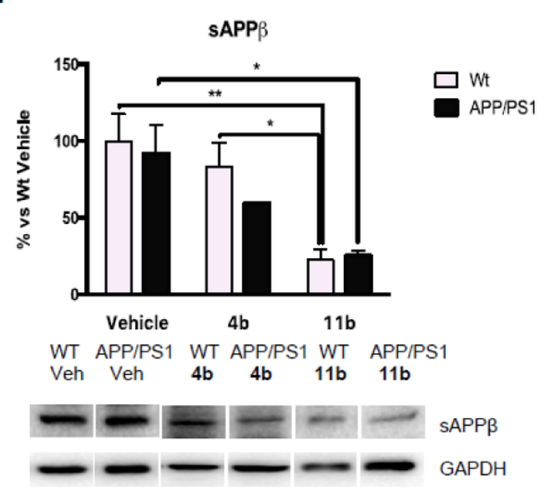

Figure 9. Gene expression of (A) Adam10 ( $\alpha$-secretase) and (B) Bace1 ( $\beta$-secretase); representative Western blot and quantification for (C) ADAM10, (D) BACE-1, (E) sAPP $\alpha$, and (F) sAPP $\beta$ in cortical samples from treated male mice (WT vehicle, $n=6$; WT 4b, $n=5$; WT 11b, $n=6$; APP/PS1 vehicle, $n=5$; APP/PS1 4b, $n=7$; APP/PS1 11b, $n=6$ ). Data are expressed as the mean values \pm SEM. Data were analyzed by two-way ANOVA with genotype and as between factors, followed by two-tailed Student's $t$-test to compare between genotypes or Tukey's post hoc test to compare between treatments. ${ }^{*} p<0.05, * * p<0.01, * * * p<0.001$; and $* * * * p<0.0001$.

$1,2,4$, and 7 of tacrine have been suggested to account for its hepatotoxic effects. ${ }^{45}$ However, these toxic effects are not shared by all tacrine derivatives. For example, a recently reported family of trolox-tacrine hybrids, featuring a chromanbased trolox moiety, a tacrine or 6-chlorotacrine unit, and oligomethylene linkers functionalized with an amide group were found to be in general less toxic to human hepatoma HepG2 cells than tacrine and 6-chlorotacrine. ${ }^{46}$ The almost negligible toxicity on human hepatic cells of some of these compounds could be ascribed to the formation of nontoxic metabolites, as suggested by in vitro microsomal stability studies. After $1 \mathrm{~h}$ of incubation of one of these troloxchlorotacrine hybrids (Figure 13) with human liver microsomes, no significant metabolic changes in the 6-chlorotacrine unit of the hybrid were found, i.e., potentially toxic hydroxylated tacrine metabolites were not formed. ${ }^{46}$ Instead, the main metabolite resulted from the reactivity of the chroman trolox moiety, namely, a $p$-benzoquinone arising from oxidative ring opening (Figure 13). ${ }^{46}$ The oxidative opening of the chroman ring might be another potential focus of reactive metabolites and, hence, of toxicity, as the benzoquinone could react as a Michael acceptor with nucleophilic protein residues. However, this did not seem to be the case, in light of the reported negligible toxicity of the trolox-tacrine hybrid both in vitro against human hepatocytes and also in acute toxicity studies on rats. ${ }^{46}$

This type of $p$-benzoquinone metabolite has been also reported for other chroman derivatives, such as the naturally occurring $\gamma$-tocopherol and $\alpha$-tocopherol. Actually, in the latter case, the $p$-benzoquinone has been found to be the major metabolite in vivo (Figure 13). ${ }^{47}$ Interestingly, not only does the $p$-benzoquinone metabolite of $\alpha$-tocopherol not cause toxicity but also it is efficiently reduced by several biological systems, including rat liver microsomal, mitochondrial, and 
A

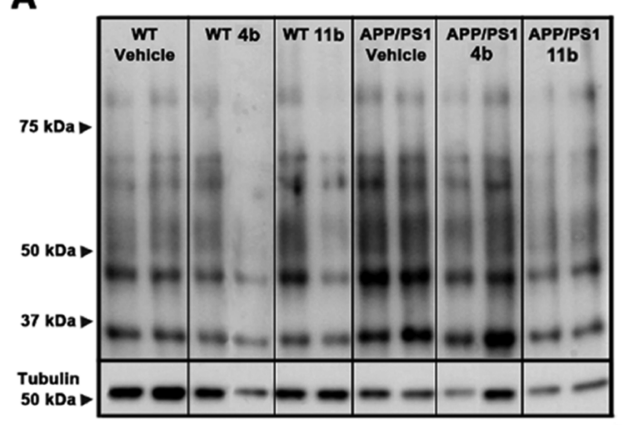

B

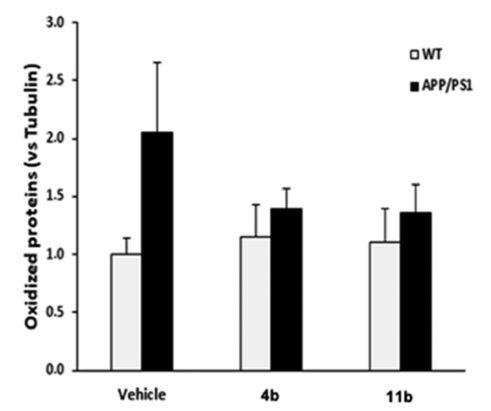

Figure 10. (A) Representative immunoblot for oxidized proteins (upper panel) and corresponding $\beta$-tubulin loading control (lower panel) from cortical samples of treated male mice (WT vehicle, $n=6$; WT $4 \mathbf{b}, n=5$; WT $11 \mathbf{b}, n=6$; APP/PS1 vehicle, $n=5$; APP/PS1 4b, $n=7$; APP/PS1 $11 \mathrm{~b}, n=6$ ). Black triangular arrows indicate the molecular weight of proteins. (B) Optical density quantification of the immunoblots normalized with respect to the WT-vehicle group. Data are expressed as the mean values \pm SEM and were analyzed by two-way ANOVA with genotype $(p<$ 0.05 ) and treatment as between factors, followed by two-tailed Student's $t$-test to compare between genotypes.

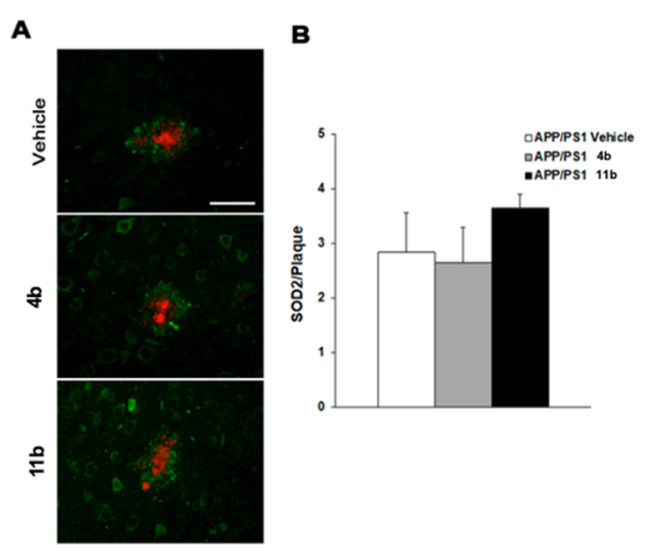

Figure 11. (A) Representative images of double SOD2 (green) and A $\beta$ (red) immunostaining in cortical sections of male APP/PS1 mice chronically treated with vehicle $(n=5), \mathbf{4 b}(n=7)$, or $\mathbf{1 1} \mathbf{b}(n=6)$. The scale bar represents $50 \mu \mathrm{m}$. (B) Quantification of the SOD2 staining around the $A \beta$ plaques reveals a tendency to increase the levels of this enzyme involved in ROS neutralization in 11b-treated $\mathrm{APP} / \mathrm{PS} 1$ mice with respect to vehicle-treated mice, but this increase does not reach the statistical significance. Data are expressed as the mean values \pm SEM and were analyzed by one-way ANOVA with treatment as between factors (not significant).

cytosolic preparations, to form the corresponding hydroquinone metabolite, which is indeed more important for the antioxidant activity than $\alpha$-tocopherol itself. ${ }^{48}$

Likewise, it has been reported that incubation of CR-6 with rat liver microsomes leads to the formation of the $p$ benzoquinone metabolite, in equilibrium with its ring-closed spiro derivative arising from a nonenzymatically promoted cyclization, and the corresponding hydroquinone (Figure 13). ${ }^{49}$ Also in this case, the formation of the potentially toxic benzoquinone did not seem to be an issue, as the in vivo toxicity of CR-6 is very low.

In light of these precedents, it seemed quite likely that the structurally related CR-6-chlorotacrine hybrids could undergo a similar metabolic fate. Notwithstanding that, the stability of the CR-6-chlorotacrine hybrid $\mathbf{4 b}$ in biological media was assessed. In particular, we determined its stability in human, mouse, and rat plasma and liver microsomes, and we performed a qualitative determination of its metabolites after incubation with human, mouse, and rat liver microsomes.
The plasma stability of compound $\mathbf{4 b}$ was assessed by incubating it at $37^{\circ} \mathrm{C}$ at different times $(0,60,180$, and 360 min) in human, mouse, and rat plasma and determining the residual amount of compound (expressed as residual percentage over starting amount) by ultraperformance liquid chromatography-tandem mass spectrometry (UPLC-MS/MS). Compound $4 \mathrm{~b}$ turned out to be fully stable up to $6 \mathrm{~h}$ in human, mouse, and rat plasma (Table 2).

Next, the microsomal stability of compound $\mathbf{4 b}$ was assessed by incubating it at $37^{\circ} \mathrm{C}$ at different times $(0,10,20,40$, and $60 \mathrm{~min}$ ) with human, mouse, and rat liver microsomes, using testosterone as a reference compound of known short half-life. The stability parameters are summarized in Table 3.

Compound $\mathbf{4 b}$ was apparently transformed to a great extent upon incubation with human liver microsomes, with 44.0, 18.6, and $3.6 \%$ of the initial amount of compound remaining unaltered after $20 \mathrm{~min}, 40 \mathrm{~min}$, and $1 \mathrm{~h}$, respectively. These results imply a short half-life $(12.6 \mathrm{~min})$ and a high microsomal intrinsic clearance $\left(\mathrm{CL}_{\text {int }}\right)$. In contrast, compound $4 \mathbf{b}$ turned out to be much more stable after incubation with mouse and rat liver microsomes, where half-lives of 50.5 and $42.4 \mathrm{~min}$, respectively, were found, with a significant amount of $4 \mathrm{~b}, 55.2$ and $36.5 \%$, respectively, remaining unchanged after $1 \mathrm{~h}$ (Table 3 ). The stability of $\mathbf{4 b}$ was particularly favorable in mouse liver microsomes, from which it can be categorized as a lowclearance compound $\left[\mathrm{CL}_{\text {int }}<15 \mu \mathrm{L} /(\mathrm{min} / \mathrm{mg}\right.$ protein $\left.)\right] .{ }^{50}$

Finally, the supernatants of the microsomal stability assays with human, mouse, and rat liver microsomes were qualitatively analyzed using a UPLC-MS/MS system to identify potential metabolites of $\mathbf{4 b}$. As expected, the $p$ benzoquinone metabolite $\mathbf{M 1}$ resulting from oxidative opening of the chroman ring, likely together with its ring-closed spiro derivative M2, seemed to have been formed (Figure 14). Interestingly, the hydroquinone metabolite $\mathbf{M} 3$ resulting from reduction of M1 was also found, as it was 6-chlorotacrine (M4), whereas, as it had been reported for the trolox-tacrine hybrids, potentially toxic hydroxylated tacrine metabolites were not detected.

Compound 4b and metabolites M1-M3 have similar structures, and all of them, as well as metabolite M4, should have a very similar degree of ionization. Even though the analysis was only qualitative, a rough comparison of the MS peak areas of $\mathbf{4} \mathbf{b}$ and its metabolites seems to indicate that (i) compound $\mathbf{4 b}$ was more abundant than any metabolite at all of the tested times in mouse and rat liver microsomes but not in 
A

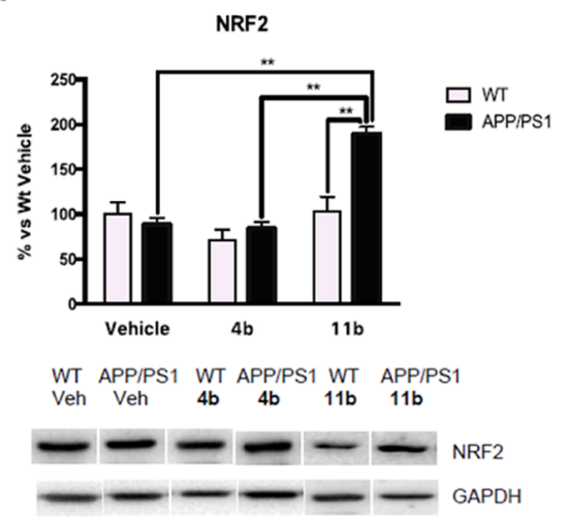

C

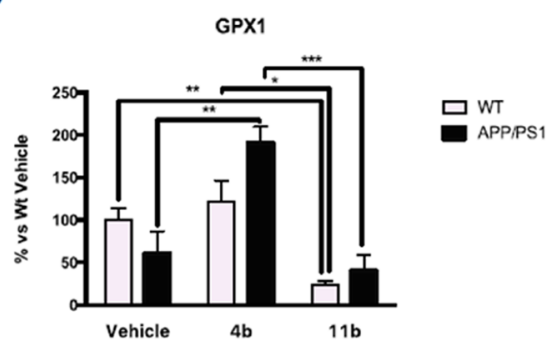

WT APPIPS1 WT APP/PS1 WT APP/PS1

Veh Veh 4b 4b 11b 11b

$-1-1-1-1$

$---1-\mathrm{GAPDH}$

E

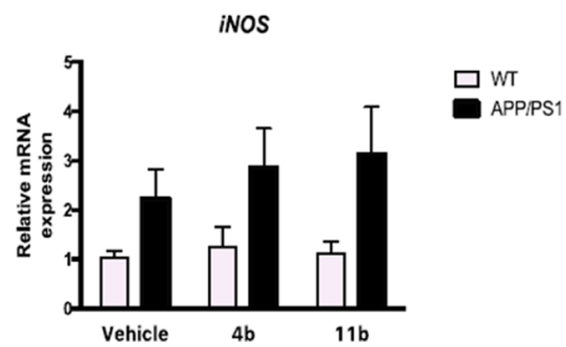

B

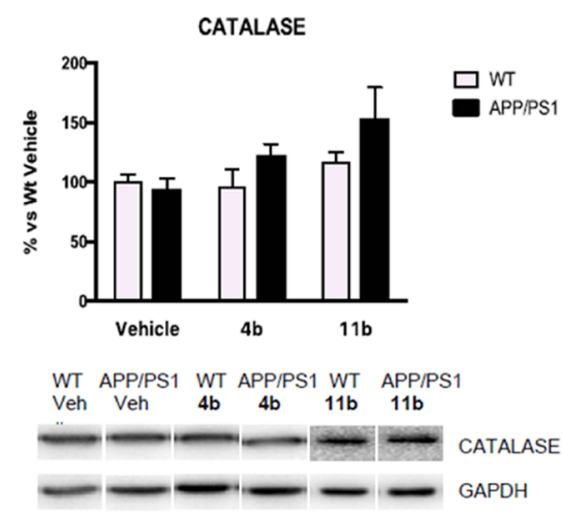

D

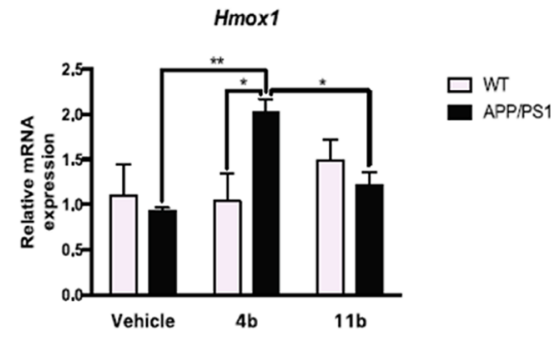

Figure 12. Representative Western blot and quantification for Nrf2 (A), catalase (B), and GPX1 (C) in cortical samples from treated male mice (WT vehicle, $n=6$; WT 4b, $n=5$; WT 11b, $n=6$; APP/PS1 vehicle, $n=5$; APP/PS1 4b, $n=7$; APP/PS1 11b, $n=6$ ). Data show a tendency to increase in antioxidant defense markers in APP/PS1 mice treated with the novel hybrids $\mathbf{4 b}$ or $\mathbf{1 1} \mathbf{b}$. Moreover, $\mathbf{4 b}$ treatment increases GPX1 levels in APP/PS1 mice compared to the vehicle group. Representative gene expression of Hmoxl (D) and iNOS (E). Hybrids $\mathbf{4 b}$ and $\mathbf{1 1 b}$ seem to increase Hmoxl and $i N O S$ gene expression, but only $\mathbf{4 b}$ in the first case reaches statistical significance. Data are expressed as the mean values \pm SEM and were analyzed by two-way ANOVA with genotype and as between factors, followed by two-tailed Student's t-test to compare between genotypes or Tukey's post hoc test to compare between treatments. ${ }^{*} p<0.05,{ }^{*} p<0.01$, and $* * * p<0.001$.

human liver microsomes after $40 \mathrm{~min}$ incubation and (ii) metabolite M4 (6-chlorotacrine) seemed to be clearly less abundant than M1-M2 and M3 (Table S4 in the Supporting Information).

The favorable stability of compound $\mathbf{4 b}$ found in mouse plasma and mouse liver microsomes might suggest that the effects observed in the in vivo efficacy studies in mice should mostly derive from $\mathbf{4} \mathbf{b}$ itself. Like for other chroman derivatives (Figure 13), the $p$-benzoquinone resulting from oxidative ring opening seems to be a major metabolite, which could contribute to the biological activity. Thus, we cannot rule out the possibility that this metabolite, after reduction to the corresponding hydroquinone, can be, in part, responsible for the in vivo effects on oxidative stress markers, as reported for $\alpha$-tocopherol. By contrast, it is not very likely that this metabolite retains the anticholinesterase activity of the parent compound $\mathbf{4} \mathbf{b}$ because its benzoquinone ring should protrude from the mouth of the gorge of hAChE (see Figure S5 in the Supporting Information). Finally, the fact that hydroxylated tacrine metabolites are not formed from $4 \mathbf{b}$ seems to be in line with its apparent lack of toxicity in mice after 4 weeks of treatment.

\section{CONCLUSIONS}

Because oxidative stress has a prominent role in the multifactorial pathogenesis of $\mathrm{AD}$, antioxidant agents are regarded as a promising therapeutic strategy. However, antioxidants have failed to demonstrate efficacy in clinical 


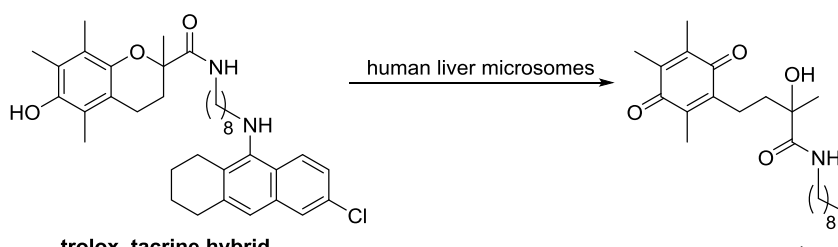

trolox-tacrine hybrid
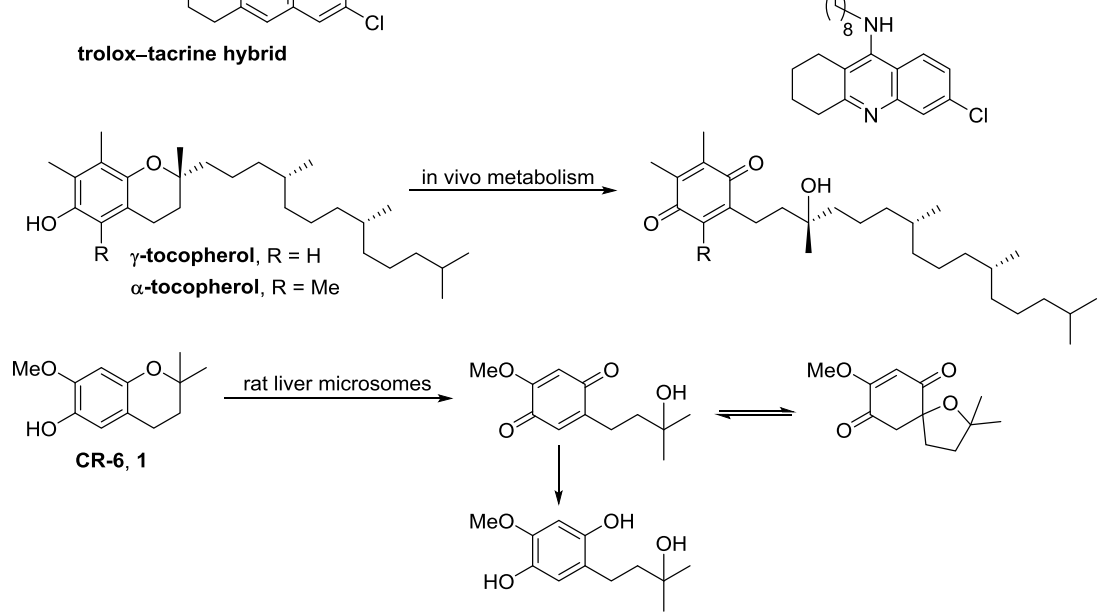

Figure 13. Reported metabolic transformation of chroman derivatives. ${ }^{46-49}$

Table 2. Stability of Compound $4 \mathrm{~b}$ in Human, Mouse, and Rat Plasma at $37^{\circ} \mathrm{C}^{a}$

\begin{tabular}{lcccc} 
& \multicolumn{4}{c}{ remaining percentage $(\%)$ of compound $\mathbf{4 b}$} \\
\cline { 2 - 5 } & $0 \mathrm{~min}$ & $60 \mathrm{~min}$ & $180 \mathrm{~min}$ & $360 \mathrm{~min}$ \\
human plasma & 100 & 100 & 100 & 100 \\
mouse plasma & 100 & 100 & 100 & 100 \\
rat plasma & 100 & 100 & 100 & 98
\end{tabular}

${ }^{a}$ Values are expressed as the mean of two independent experiments, each performed in triplicate.

trials so far. These failures could be ascribed to the poor brain permeability of antioxidants and to the fact that other pathogenic mechanisms of $\mathrm{AD}$ should be hit in addition to oxidative stress to efficiently cope with the multifactorial nature of this disease. Here, we have shown that molecular hybridization of the promising but non-brain-permeable antioxidant lead CR-6 with the potent lipophilic AChE inhibitor 6-chlorotacrine is a good approach to overcome both limitations. On the one hand, the resulting CR-6chlorotacrine hybrids displayed favorable brain permeabilities, as measured in the in vitro PAMPA-BBB assay. On the other hand, the novel hybrids displayed multiple biological activities in vitro, including picomolar-to-nanomolar hAChE and nanomolar hBChE inhibitory activities, apart from the antioxidant effect. Indeed, the combination of the CR-6 and 6-chlorotacrine scaffolds had a synergistic effect, with the hybrids being up to 120 - and 40 -fold more potent toward hAChE and hBChE than the parent 6-chlorotacrine, while retaining or displaying slightly improved antioxidant activity relative to the lead CR-6. Interestingly, some hybrids exhibited moderate in vitro activities against other key targets, such as $\mathrm{BACE}-1$ and $\mathrm{A} \beta 42$ and tau aggregation. Chronic in vivo efficacy studies with two selected compounds in doubletransgenic APP/PS1 mice have shown positive tendencies in improving cognition, amyloid pathology (reduction of amyloid burden and potentiation of the non-amyloidogenic APP processing pathway), and oxidative stress (reduction of the levels of oxidized proteins and increase of the levels of antioxidant enzymes). Even though most of the observed in vivo effects did not reach statistical significance, it was found that compounds $\mathbf{4 b}$ and $\mathbf{1 1 b}$ significantly reduced Bacel gene expression, with the latter compound also reducing brain sAPP $\beta$ protein levels and increasing Adam 10 gene expression. Significant in vivo effects were also found regarding some oxidative stress markers, namely, increased brain GPX1 protein levels and Hmox 1 expression, and increased Nrf2 protein levels upon treatment with $\mathbf{4 b}$ and $\mathbf{1 1} \mathbf{b}$, respectively. By virtue of their moderate in vivo effects, these compounds constitute interesting brain-permeable multitarget anti-Alzheimer leads.

\section{EXPERIMENTAL SECTION}

Chemistry. All reagents and solvents were obtained from commercial suppliers and used without further purification. The progress of the reactions was monitored by thin-layer chromatography (TLC) on aluminum-backed sheets with silica gel $60 \mathrm{~F}_{254}$ (Merck, ref 1.05554) using $\mathrm{CH}_{2} \mathrm{Cl}_{2} / \mathrm{MeOH} / 50 \%$ aq $\mathrm{NH}_{4} \mathrm{OH}$ 95:5:1 (4a-d, $12 a-c, 12 e$, and $5 a-c)$ or 90:10:1 (6a-d, 11a-c, and 11e) as a

Table 3. Stability of Compound $4 \mathrm{~b}$ in Human, Mouse, and Rat Liver Microsomes at $37{ }^{\circ} \mathrm{C}^{a}$

\begin{tabular}{|c|c|c|c|c|c|c|c|c|c|}
\hline \multirow[b]{2}{*}{ compound } & \multicolumn{3}{|c|}{ human microsomes } & \multicolumn{3}{|c|}{ mouse microsomes } & \multicolumn{3}{|c|}{ rat microsomes } \\
\hline & $\begin{array}{l}\text { residual } \\
\text { amount } \\
(\%)\end{array}$ & $\begin{array}{c}t_{1 / 2} \\
(\mathrm{~min})\end{array}$ & {$\left[\mu \mathrm{CL}_{\text {int }}\right.$} & $\begin{array}{c}\text { residual } \\
\text { amount } \\
(\%)\end{array}$ & $\begin{array}{c}t_{1 / 2} \\
(\mathrm{~min})\end{array}$ & {$\left[\mu \mathrm{CL}_{\text {int }}\right.$} & $\begin{array}{l}\text { residual } \\
\text { amount } \\
(\%)\end{array}$ & $\begin{array}{c}t_{1 / 2} \\
(\mathrm{~min})\end{array}$ & {$\left[\begin{array}{c}\mathrm{CL}_{\text {int }} \\
{[\mu \mathrm{L} /(\mathrm{min} / \mathrm{mg} \text { protein })]}\end{array}\right.$} \\
\hline $4 b$ & 3.6 & 12.6 & 55.2 & 55.2 & 50.5 & 13.7 & 36.5 & 42.4 & 16.3 \\
\hline testosterone & 6.1 & 9.9 & 69.7 & 14.7 & 13.7 & 50.7 & 2.9 & 2.4 & 286.2 \\
\hline
\end{tabular}

${ }^{a}$ Values are expressed as the mean of two independent experiments, each performed in triplicate. 


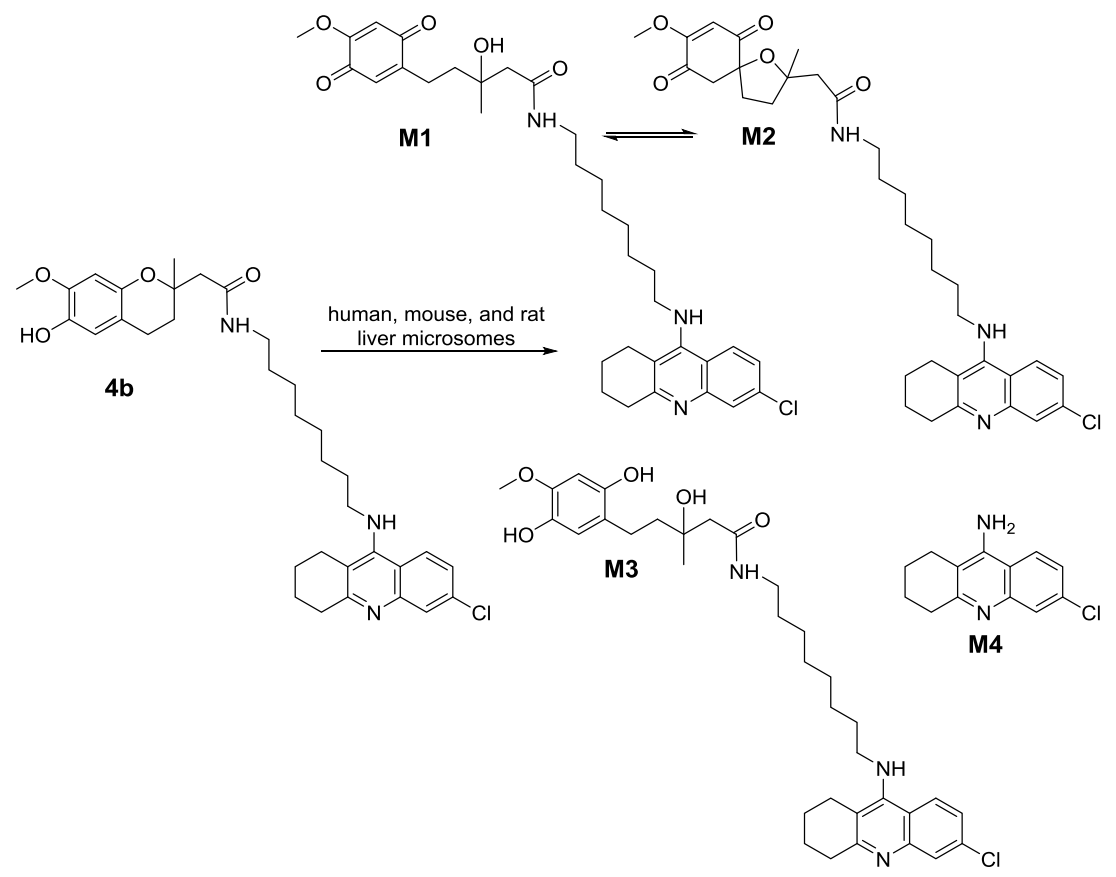

Figure 14. Metabolites of compound $\mathbf{4 b}$ found after incubation with human, mouse, and rat liver microsomes.

solvent system. The spots were visualized by UV irradiation and/or $1 \%$ aq $\mathrm{KMnO}_{4}$, followed by charring with a heat gun. Column chromatography was performed on silica gel 60 AC.C (35-70 mesh, safety data sheet (SDS), ref 2000027). Melting points were determined in open capillary tubes with an MFB 595010M Gallenkamp melting point apparatus. IR spectra were run on a PerkinElmer Spectrum RX I spectrophotometer. Absorption values are expressed as wavenumbers $\left(\mathrm{cm}^{-1}\right)$; only significant absorption bands are given. Furthermore, $400 \mathrm{MHz}{ }^{1} \mathrm{H} / 100.6 \mathrm{MHz}{ }^{13} \mathrm{C}$ NMR spectra were recorded on a Varian Mercury 400 spectrometer, at the Centres Científics i Tecnològics of the University of Barcelona (CCiTUB). The chemical shifts are reported in $\mathrm{ppm}(\delta$ scale $)$ relative to solvent signals $\left(\mathrm{CD}_{3} \mathrm{OD}\right.$ at 3.31 and $49.0 \mathrm{ppm}$ in the ${ }^{1} \mathrm{H}$ and ${ }^{13} \mathrm{C}$ NMR spectra, respectively), and coupling constants are reported in hertz $(\mathrm{Hz})$. Assignments given for the NMR spectra of the new compounds have been carried out by comparison with the NMR data of compounds $4 \mathrm{~b}, 4 \mathrm{~d}, 5 \mathrm{~b}, 6 \mathrm{~b}, 6 \mathrm{~d}$, and $11 \mathrm{~b}$, which, in turn, were assigned on the basis of correlation spectroscopy (COSY) ${ }^{1} \mathrm{H} /{ }^{1} \mathrm{H}$ (standard procedures) and $\operatorname{COSY}{ }^{1} \mathrm{H} /{ }^{13} \mathrm{C}$ (gHSQC and gHMBC sequences) experiments. High-resolution mass spectra were carried out at the CCiTUB with an LC/MSD TOF Agilent Technologies spectrometer. Analytical reversed-phase (RP) HPLC was performed with a Hewlett Packard series 110 modular system equipped with a UV detector 1315A, using an RP Kromasil $100 \mathrm{C} 18\left(15 \times 0.46 \mathrm{~cm}^{2}, 5\right.$ $\mu \mathrm{m})$ column, $\mathrm{CH}_{3} \mathrm{CN} / \mathrm{H}_{2} \mathrm{O}$ mixtures containing $0.1 \%$ trifluoroacetic acid (TFA) (gradient from 20 to $100 \% \mathrm{CH}_{3} \mathrm{CN}$ in $20 \mathrm{~min}$ ) as the eluent, a flow of $1 \mathrm{~mL} / \mathrm{min}, \lambda=254 \mathrm{~nm}$. The analytical samples of all of the compounds that were subjected to pharmacological evaluation possessed a purity $\geq 95 \%$ as evidenced by HPLC measurements.

$N$-\{7-[(6-Chloro-1,2,3,4-tetrahydroacridin-9-yl)amino]heptyl\}-2(6-hydroxy-7-methoxy-2-methylchroman-2-yl)acetamide (4a). A solution of carboxylic acid $7(166 \mathrm{mg}, 0.66 \mathrm{mmol})$ in a mixture of EtOAc $(9.7 \mathrm{~mL})$ and DMF $(0.5 \mathrm{~mL})$ was treated with $\mathrm{N}$-(3dimethylaminopropyl)- $N^{\prime}$-ethylcarbodiimide hydrochloride (EDC. $\mathrm{HCl}, 153 \mathrm{mg}, 0.80 \mathrm{mmol}), \mathrm{Et}_{3} \mathrm{~N}(0.18 \mathrm{~mL}, 131 \mathrm{mg}, 1.30 \mathrm{mmol})$, and 1-hydroxy-1H-benzotriazole (HOBt, $134 \mathrm{mg}, 0.99 \mathrm{mmol}$ ). The resulting mixture was stirred at $\mathrm{rt}$ for $15 \mathrm{~min}$ and then treated with a suspension of amine 10a $(250 \mathrm{mg}, 0.72 \mathrm{mmol})$ in a mixture of EtOAc $(10 \mathrm{~mL})$ and DMF $(1.5 \mathrm{~mL})$. The reaction mixture was stirred at $\mathrm{rt}$ for 1 day and was concentrated in vacuo to give a dark brown solid (763 mg), which was purified by column chromatography (35-70 $\mu \mathrm{m}$ silica gel, hexane $/ \mathrm{EtOAc} / \mathrm{Et}_{3} \mathrm{~N}$ mixtures, gradient elution). On elution with hexane/EtOAc/ $\mathrm{Et}_{3} \mathrm{~N}$ 20:80:0.2, amide 4a (254 mg, 67\% yield) was isolated as a white solid; $R_{f} 0.62\left(\mathrm{CH}_{2} \mathrm{Cl}_{2} / \mathrm{MeOH} / 50 \%\right.$ aq $\mathrm{NH}_{4} \mathrm{OH}$ 95:5:1).

A solution of $4 \mathrm{a}(237 \mathrm{mg}, 0.41 \mathrm{mmol})$ in $\mathrm{CH}_{2} \mathrm{Cl}_{2}(2 \mathrm{~mL})$ was filtered through a $0.22 \mu \mathrm{m}$ poly(vinylidene difluoride) (PVDF) filter, treated with $\mathrm{HCl} / \mathrm{Et}_{2} \mathrm{O}(1.35 \mathrm{~N}, 0.9 \mathrm{~mL})$, and evaporated under reduced pressure. The resulting solid was washed with pentane $(3 \times 2$ $\mathrm{mL})$ to give, after drying at $40{ }^{\circ} \mathrm{C} / 30$ Torr for $48 \mathrm{~h}, 4 \mathrm{a} \cdot \mathrm{HCl}(232 \mathrm{mg})$ as a yellowish solid: $\mathrm{mp} 122-126^{\circ} \mathrm{C}$; IR (attenuated total reflection (ATR)) $\nu$ 3600-2200 (max at 3244, 3065, 2927, 2852, N-H, $\mathrm{N}^{+}-\mathrm{H}$, $\mathrm{O}-\mathrm{H}, \mathrm{C}-\mathrm{H}$ st $), 1632,1573,1509(\mathrm{C}=\mathrm{O}, \mathrm{Ar}-\mathrm{C}-\mathrm{C}, \mathrm{Ar}-\mathrm{C}-\mathrm{N}$ st $)$ $\mathrm{cm}^{-1}$; ${ }^{1} \mathrm{H}$ NMR $\left(400 \mathrm{MHz}, \mathrm{CD}_{3} \mathrm{OD}\right) \delta 1.31\left(\mathrm{~s}, 3 \mathrm{H}, 2-\mathrm{CH}_{3}\right), 1.31-$ 1.41 (complex signal, $\left.6 \mathrm{H}, 3^{\prime}-\mathrm{H}_{2}, 4^{\prime}-\mathrm{H}_{2}, 5^{\prime}-\mathrm{H}_{2}\right), 1.49\left(\mathrm{tt}, J=J^{\prime}=6.8\right.$ $\left.\mathrm{Hz}, 2 \mathrm{H}, 2^{\prime}-\mathrm{H}_{2}\right)$, superimposed in part $1.77\left(\mathrm{dt}, J=13.2 \mathrm{~Hz}, J^{\prime}=6.8\right.$ $\left.\mathrm{Hz}, 1 \mathrm{H}, 3-\mathrm{H}_{\mathrm{A}}\right), 1.79\left(\mathrm{~m}, 2 \mathrm{H}, 6^{\prime}-\mathrm{H}_{2}\right), 1.89\left(\mathrm{dt}, J=13.2 \mathrm{~Hz}, J^{\prime}=7.2\right.$ $\mathrm{Hz}, 1 \mathrm{H}, 3-\mathrm{H}_{\mathrm{B}}$ ), $1.91-2.00$ (complex signal, $4 \mathrm{H}, 2^{\prime \prime}-\mathrm{H}_{2}, 3^{\prime \prime}-\mathrm{H}_{2}$ ), 2.44 $\left(\mathrm{d}, J=13.6 \mathrm{~Hz}, 1 \mathrm{H}, 2-\mathrm{CH}_{\mathrm{A}}-\mathrm{CO}\right), 2.48\left(\mathrm{~d}, J=13.6 \mathrm{~Hz}, 1 \mathrm{H}, 2-\mathrm{CH}_{\mathrm{B}}-\right.$ $\mathrm{CO}), 2.61\left(\mathrm{dd}, J=7.2 \mathrm{~Hz}, J^{\prime}=6.8 \mathrm{~Hz}, 2 \mathrm{H}, 4-\mathrm{H}_{2}\right), 2.65(\mathrm{t}, J=6.4 \mathrm{~Hz}$, $\left.2 \mathrm{H}, 1^{\prime \prime}-\mathrm{H}_{2}\right), 2.99\left(\mathrm{t}, J=5.6 \mathrm{~Hz}, 2 \mathrm{H}, 4^{\prime \prime}-\mathrm{H}_{2}\right), 3.16\left(\mathrm{dt}, J=13.6 \mathrm{~Hz}, J^{\prime}=\right.$ $\left.6.8 \mathrm{~Hz}, 1 \mathrm{H}, 1^{\prime}-\mathrm{H}_{\mathrm{A}}\right), 3.20\left(\mathrm{dt}, J=13.6 \mathrm{~Hz}, J^{\prime}=6.8 \mathrm{~Hz}, 1 \mathrm{H}, 1^{\prime}-\mathrm{H}_{\mathrm{B}}\right)$, $3.73\left(\mathrm{~s}, 3 \mathrm{H}, 7-\mathrm{OCH}_{3}\right), 3.89\left(\mathrm{t}, J=7.2 \mathrm{~Hz}, 2 \mathrm{H}, 7^{\prime}-\mathrm{H}_{2}\right), 4.85(\mathrm{~s}, \mathrm{NH}$, $\left.{ }^{+} \mathrm{NH}, \mathrm{OH}\right), 6.31(\mathrm{~s}, 1 \mathrm{H}, 8-\mathrm{H}), 6.44(\mathrm{~s}, 1 \mathrm{H}, 5-\mathrm{H}), 7.55(\mathrm{dd}, J=9.2 \mathrm{~Hz}$, $\left.J^{\prime}=2.0 \mathrm{~Hz}, 1 \mathrm{H}, 7^{\prime \prime}-\mathrm{H}\right), 7.77\left(\mathrm{~d}, J=2.0 \mathrm{~Hz}, 1 \mathrm{H}, 5^{\prime \prime}-\mathrm{H}\right), 8.36(\mathrm{~d}, J=9.2$ $\left.\mathrm{Hz}, 1 \mathrm{H}, 8^{\prime \prime}-\mathrm{H}\right) ;{ }^{13} \mathrm{C}$ NMR (100.6 MHz, $\left.\mathrm{CD}_{3} \mathrm{OD}\right) \delta 21.7\left(\mathrm{CH}_{2}, \mathrm{C}^{\prime \prime}\right)$, $22.4\left(\mathrm{CH}_{2}, \mathrm{C} 4\right), 22.8\left(\mathrm{CH}_{2}, \mathrm{C} 2^{\prime \prime}\right), 24.5\left(\mathrm{CH}_{3}, 2-\mathrm{CH}_{3}\right), 24.7\left(\mathrm{CH}_{2}\right.$, $\left.\mathrm{C}^{\prime \prime}\right), 27.6\left(\mathrm{CH}_{2}, \mathrm{C}^{\prime}\right), 27.7\left(\mathrm{CH}_{2}, \mathrm{C} 4^{\prime}\right), 29.3\left(\mathrm{CH}_{2}, \mathrm{C} 4^{\prime \prime}\right), 29.9$ $\left(\mathrm{CH}_{2}, \mathrm{C}^{\prime}\right), 30.3\left(\mathrm{CH}_{2}, \mathrm{C}^{\prime}\right), 31.3\left(\mathrm{CH}_{2}, \mathrm{C}^{\prime}\right), 32.3\left(\mathrm{CH}_{2}, \mathrm{C} 3\right), 40.1$ $\left(\mathrm{CH}_{2}, \mathrm{Cl}^{\prime}\right), 47.5\left(\mathrm{CH}_{2}, 2-\mathrm{CH}_{2}-\mathrm{CO}\right), 49.3\left(\mathrm{CH}_{2}, \mathrm{C}^{\prime}\right), 56.4\left(\mathrm{CH}_{3}, 7-\right.$ $\left.\mathrm{OCH}_{3}\right), 75.6(\mathrm{C}, \mathrm{C} 2), 102.2(\mathrm{CH}, \mathrm{C} 8), 113.3\left(\mathrm{C}, \mathrm{C} 9 \mathrm{a}^{\prime \prime}\right), 113.4(\mathrm{C}$, C4a), 115.4 (C, C8a"), 116.1 (CH, C5), $119.1\left(\mathrm{CH}, \mathrm{C5}^{\prime \prime}\right), 126.8$ $(\mathrm{CH}, \mathrm{C} 7 "), 128.7\left(\mathrm{CH}, \mathrm{C} 8^{\prime \prime}\right), 140.1\left(\mathrm{C}, \mathrm{C6}{ }^{\prime \prime}\right), 140.5$ (C, C10a"), 141.1 (C, C6), 147.4 (C, C8a), 148.3 (C, C7), 152.1 (C, C4a"), 157.8 (C, C9"), 172.4 (C, CONH); HRMS (electrospray ionization (ESI)) calcd for $\left(\mathrm{C}_{33} \mathrm{H}_{42}{ }^{35} \mathrm{ClN}_{3} \mathrm{O}_{4}+\mathrm{H}^{+}\right)$: 580.2937, found 580.2927; HPLC purity $100 \%$.

$N$-\{8-[(6-Chloro-1,2,3,4-tetrahydroacridin-9-yl)amino]octyl\}-2(6-hydroxy-7-methoxy-2-methylchroman-2-yl)acetamide (4b). It was prepared as described for 4a. From carboxylic acid 7 (120 mg, $0.48 \mathrm{mmol}$ ) and amine $10 \mathrm{~b}(188 \mathrm{mg}, 0.52 \mathrm{mmol})$, a brown sticky solid $(624 \mathrm{mg})$ was obtained and subjected to column chromatography purification $\left(35-70 \mu \mathrm{m}\right.$ silica gel, hexane/EtOAc/ $/ \mathrm{Et}_{3} \mathrm{~N}$ mixtures, gradient elution). On elution with hexane/EtOAc/ $\mathrm{Et}_{3} \mathrm{~N}$ 
20:80:0.2, amide $4 \mathrm{~b}$ (189 $\mathrm{mg}, 67 \%$ yield) was isolated as a yellowish solid; $R_{f} 0.63\left(\mathrm{CH}_{2} \mathrm{Cl}_{2} / \mathrm{MeOH} / 50 \%\right.$ aq $\mathrm{NH}_{4} \mathrm{OH}$ 95:5:1).

4b $\cdot \mathrm{HCl}$ : beige solid; mp $127-130{ }^{\circ} \mathrm{C}$; IR (ATR) $\nu$ 3600-2200 ( $\max$ at $3244,3059,2927,2854, \mathrm{~N}-\mathrm{H}, \mathrm{N}^{+}-\mathrm{H}, \mathrm{O}-\mathrm{H}, \mathrm{C}-\mathrm{H}$ st), 1632, $1573,1510(\mathrm{C}=\mathrm{O}, \mathrm{Ar}-\mathrm{C}-\mathrm{C}, \mathrm{Ar}-\mathrm{C}-\mathrm{N} \mathrm{st}) \mathrm{cm}^{-1} ;{ }^{1} \mathrm{H}$ NMR (400 $\mathrm{MHz}, \mathrm{CD}_{3} \mathrm{OD}$ ) $\delta$ 1.27-1.34 (complex signal, $6 \mathrm{H}, 3^{\prime}-\mathrm{H}_{2}, 4^{\prime}-\mathrm{H}_{2}, 5^{\prime}-$ $\left.\mathrm{H}_{2}\right), 1.31\left(\mathrm{~s}, 3 \mathrm{H}, 2-\mathrm{CH}_{3}\right), 1.39\left(\mathrm{tt}, J=J^{\prime}=6.8 \mathrm{~Hz}, 2 \mathrm{H}, 6^{\prime}-\mathrm{H}_{2}\right), 1.48$ $\left(\mathrm{tt}, J=J^{\prime}=6.8 \mathrm{~Hz}, 2 \mathrm{H}, 2^{\prime}-\mathrm{H}_{2}\right)$, superimposed in part $1.75(\mathrm{dt}, J=13.6$ $\left.\mathrm{Hz}, J^{\prime}=6.8 \mathrm{~Hz}, 1 \mathrm{H}, 3-\mathrm{H}_{\mathrm{A}}\right), 1.80\left(\mathrm{tt}, J=7.2 \mathrm{~Hz}, J^{\prime}=6.8 \mathrm{~Hz}, 2 \mathrm{H}, 7^{\prime}\right.$ $\left.\mathrm{H}_{2}\right), 1.89\left(\mathrm{dt}, J=13.6 \mathrm{~Hz}, J^{\prime}=6.8 \mathrm{~Hz}, 1 \mathrm{H}, 3-\mathrm{H}_{\mathrm{B}}\right), 1.92-2.00$ (complex signal, $\left.4 \mathrm{H}, 2^{\prime \prime}-\mathrm{H}_{2}, 3^{\prime \prime}-\mathrm{H}_{2}\right), 2.44\left(\mathrm{~d}, J=13.6 \mathrm{~Hz}, 1 \mathrm{H}, 2-\mathrm{CH}_{\mathrm{A}^{-}}\right.$ $\mathrm{CO}), 2.48\left(\mathrm{~d}, J=13.6 \mathrm{~Hz}, 1 \mathrm{H}, 2-\mathrm{CH}_{\mathrm{B}}-\mathrm{CO}\right), 2.62(\mathrm{t}, J=6.8 \mathrm{~Hz}, 2 \mathrm{H}$, $\left.4-\mathrm{H}_{2}\right), 2.66\left(\mathrm{t}, J=5.6 \mathrm{~Hz}, 2 \mathrm{H}, 1^{\prime \prime}-\mathrm{H}_{2}\right), 2.99\left(\mathrm{t}, J=6.0 \mathrm{~Hz}, 2 \mathrm{H}, 4^{\prime \prime}-\mathrm{H}_{2}\right)$, $3.16\left(\mathrm{dt}, J=13.6 \mathrm{~Hz}, J^{\prime}=6.8 \mathrm{~Hz}, 1 \mathrm{H}, 1^{\prime}-\mathrm{H}_{\mathrm{A}}\right), 3.20\left(\mathrm{dt}, J=13.6 \mathrm{~Hz}, J^{\prime}\right.$ $\left.=6.8 \mathrm{~Hz}, 1 \mathrm{H}, 1^{\prime}-\mathrm{H}_{\mathrm{B}}\right), 3.75\left(\mathrm{~s}, 3 \mathrm{H}, 7-\mathrm{OCH}_{3}\right), 3.90(\mathrm{t}, J=7.2 \mathrm{~Hz}, 2 \mathrm{H}$, $\left.8^{\prime}-\mathrm{H}_{2}\right), 4.85\left(\mathrm{~s}, \mathrm{NH},{ }^{+} \mathrm{NH}, \mathrm{OH}\right), 6.32(\mathrm{~s}, 1 \mathrm{H}, 8-\mathrm{H}), 6.44(\mathrm{~s}, 1 \mathrm{H}, 5-\mathrm{H})$, $7.55\left(\mathrm{dd}, J=9.2 \mathrm{~Hz}, J^{\prime}=2.4 \mathrm{~Hz}, 1 \mathrm{H}, 7^{\prime \prime}-\mathrm{H}\right), 7.76(\mathrm{~d}, J=2.4 \mathrm{~Hz}, 1 \mathrm{H}$, $\left.5^{\prime \prime}-\mathrm{H}\right), 8.36\left(\mathrm{~d}, J=9.2 \mathrm{~Hz}, 1 \mathrm{H}, 8^{\prime \prime}-\mathrm{H}\right) ;{ }^{13} \mathrm{C}$ NMR $(100.6 \mathrm{MHz}$, $\left.\mathrm{CD}_{3} \mathrm{OD}\right) \delta 21.8\left(\mathrm{CH}_{2}, \mathrm{C}^{\prime \prime}\right), 22.4\left(\mathrm{CH}_{2}, \mathrm{C} 4\right), 22.8\left(\mathrm{CH}_{2}, \mathrm{C2}^{\prime \prime}\right)$, $24.62\left(\mathrm{CH}_{3}, 2-\mathrm{CH}_{3}\right), 24.64\left(\mathrm{CH}_{2}, \mathrm{Cl}^{\prime \prime}\right), 27.5\left(\mathrm{CH}_{2}, \mathrm{C}^{\prime}\right), 27.7\left(\mathrm{CH}_{2}\right.$, $\left.\mathrm{C5}^{\prime}\right), 29.3\left(\mathrm{CH}_{2}, \mathrm{C}^{\prime \prime}\right), 30.1\left(\mathrm{CH}_{2}\right), 30.2\left(\mathrm{CH}_{2}\right)\left(\mathrm{C}^{\prime}, \mathrm{C}^{\prime}\right), 30.4$ $\left(\mathrm{CH}_{2}, \mathrm{C} 2^{\prime}\right), 31.3\left(\mathrm{CH}_{2}, \mathrm{C}^{\prime}\right), 32.3\left(\mathrm{CH}_{2}, \mathrm{C} 3\right), 40.2\left(\mathrm{CH}_{2}, \mathrm{Cl}^{\prime}\right), 47.4$ $\left(\mathrm{CH}_{2}, 2-\mathrm{CH}_{2}-\mathrm{CO}\right), 49.3\left(\mathrm{CH}_{2}, \mathrm{C} 8^{\prime}\right), 56.4\left(\mathrm{CH}_{3}, 7-\mathrm{OCH}_{3}\right), 75.6(\mathrm{C}$, C2), 102.2 (CH, C8), 113.3 (C, C9a"), 113.4 (C, C4a), 115.4 (C, $\left.\mathrm{C} 8 \mathrm{a}^{\prime \prime}\right), 116.1(\mathrm{CH}, \mathrm{C} 5), 119.1\left(\mathrm{CH}, \mathrm{C5}^{\prime \prime}\right), 126.7\left(\mathrm{CH}, \mathrm{C}^{\prime \prime}\right), 128.8$ (CH, C8"), 140.1 (C, C6"), 140.5 (C, C10a"), 141.1 (C, C6), 147.4 (C, C8a), 148.3 (C, C7), 152.0 (C, C4a"), 157.8 (C, C9"), 172.4 (C, CONH); HRMS (ESI) calcd for $\left(\mathrm{C}_{34} \mathrm{H}_{44}{ }^{35} \mathrm{ClN}_{3} \mathrm{O}_{4}+\mathrm{H}^{+}\right): 594.3093$, found 594.3096; HPLC purity $96 \%$.

$N$-\{9-[(6-Chloro-1,2,3,4-tetrahydroacridin-9-yl)amino]nonyl\}-2(6-hydroxy-7-methoxy-2-methylchroman-2-yl)acetamide (4c). It was prepared as described for 4a. From carboxylic acid 7 (163 mg, $0.65 \mathrm{mmol})$ and amine $10 \mathrm{c}(266 \mathrm{mg}, 0.71 \mathrm{mmol})$, a brown sticky solid $(828 \mathrm{mg})$ was obtained and subjected to column chromatography purification $\left(35-70 \mu \mathrm{m}\right.$ silica gel, hexane/EtOAc/Et ${ }_{3} \mathrm{~N}$ mixtures, gradient elution). On elution with hexane/EtOAc/ $\mathrm{Et}_{3} \mathrm{~N}$ 20:80:0.2, amide $4 \mathrm{c}$ (338 $\mathrm{mg}, 86 \%$ yield) was isolated as a white solid; $R_{f} 0.66\left(\mathrm{CH}_{2} \mathrm{Cl}_{2} / \mathrm{MeOH} / 50 \%\right.$ aq $\left.\mathrm{NH}_{4} \mathrm{OH} 95: 5: 1\right)$.

4c. HCl: light yellow solid; mp $104-106{ }^{\circ} \mathrm{C}$; IR (ATR) $\nu$ 36002200 ( $\max$ at 3244, 3065, 2924, 2852, N-H, N+ $-\mathrm{H}, \mathrm{O}-\mathrm{H}, \mathrm{C}-\mathrm{H}$ st), 1632, 1573, $1510(\mathrm{C}=\mathrm{O}, \mathrm{Ar}-\mathrm{C}-\mathrm{C}, \mathrm{Ar}-\mathrm{C}-\mathrm{N} \mathrm{st}) \mathrm{cm}^{-1}$; ${ }^{1} \mathrm{H}$ NMR (400 MHz, CD $\mathrm{CD}_{3} \mathrm{OD}$ ) $\delta 1.23-1.33$ (complex signal, $8 \mathrm{H}, 3^{\prime}-\mathrm{H}_{2}, 4^{\prime}-\mathrm{H}_{2}$, $\left.5^{\prime}-\mathrm{H}_{2}, 6^{\prime}-\mathrm{H}_{2}\right), 1.32\left(\mathrm{~s}, 3 \mathrm{H}, 2-\mathrm{CH}_{3}\right), 1.40\left(\mathrm{tt}, J=J^{\prime}=7.2 \mathrm{~Hz}, 2 \mathrm{H}, 7^{\prime}-\right.$ $\left.\mathrm{H}_{2}\right), 1.48\left(\mathrm{tt}, J=J^{\prime}=6.8 \mathrm{~Hz}, 2 \mathrm{H}, 2^{\prime}-\mathrm{H}_{2}\right)$, superimposed in part 1.77 $\left(\mathrm{dt}, J=13.6 \mathrm{~Hz}, J^{\prime}=6.8 \mathrm{~Hz}, 1 \mathrm{H}, 3-\mathrm{H}_{\mathrm{A}}\right), 1.80\left(\mathrm{tt}, J=J^{\prime}=7.2 \mathrm{~Hz}, 2 \mathrm{H}\right.$, $\left.8^{\prime}-\mathrm{H}_{2}\right), 1.90\left(\mathrm{dt}, J=13.6 \mathrm{~Hz}, J^{\prime}=7.2 \mathrm{~Hz}, 1 \mathrm{H}, 3-\mathrm{H}_{\mathrm{B}}\right), 1.92-2.00$ (complex signal, $\left.4 \mathrm{H}, 2^{\prime \prime}-\mathrm{H}_{2}, 3^{\prime \prime}-\mathrm{H}_{2}\right), 2.44\left(\mathrm{~d}, J=13.2 \mathrm{~Hz}, 1 \mathrm{H}, 2-\mathrm{CH}_{\mathrm{A}^{-}}\right.$ $\mathrm{CO}), 2.49\left(\mathrm{~d}, J=13.2 \mathrm{~Hz}, 1 \mathrm{H}, 2-\mathrm{CH}_{\mathrm{B}}-\mathrm{CO}\right), 2.63\left(\mathrm{dd}, J=7.2 \mathrm{~Hz}, J^{\prime}=\right.$ $\left.6.8 \mathrm{~Hz}, 2 \mathrm{H}, 4-\mathrm{H}_{2}\right), 2.67\left(\mathrm{t}, J=5.2 \mathrm{~Hz}, 2 \mathrm{H}, 1^{\prime \prime}-\mathrm{H}_{2}\right), 2.99(\mathrm{t}, J=5.2 \mathrm{~Hz}$, $\left.2 \mathrm{H}, 4^{\prime \prime}-\mathrm{H}_{2}\right), 3.16\left(\mathrm{dt}, J=13.6 \mathrm{~Hz}, J^{\prime}=6.8 \mathrm{~Hz}, 1 \mathrm{H}, 1^{\prime}-\mathrm{H}_{\mathrm{A}}\right), 3.20(\mathrm{dt}, J$ $\left.=13.6 \mathrm{~Hz}, J^{\prime}=6.8 \mathrm{~Hz}, 1 \mathrm{H}, 1^{\prime}-\mathrm{H}_{\mathrm{B}}\right), 3.75\left(\mathrm{~s}, 3 \mathrm{H}, 7-\mathrm{OCH}_{3}\right), 3.92(\mathrm{t}, J=$ $\left.7.2 \mathrm{~Hz}, 2 \mathrm{H}, 9^{\prime}-\mathrm{H}_{2}\right), 4.85\left(\mathrm{~s}, \mathrm{NH},{ }^{+} \mathrm{NH}, \mathrm{OH}\right), 6.34(\mathrm{~s}, 1 \mathrm{H}, 8-\mathrm{H}), 6.45$ $(\mathrm{s}, 1 \mathrm{H}, 5-\mathrm{H}), 7.56\left(\mathrm{dd}, J=9.2 \mathrm{~Hz}, J^{\prime}=2.0 \mathrm{~Hz}, 1 \mathrm{H}, 7^{\prime \prime}-\mathrm{H}\right), 7.76(\mathrm{~d}, J=$ $\left.2.0 \mathrm{~Hz}, 1 \mathrm{H}, 5^{\prime \prime}-\mathrm{H}\right), 8.38\left(\mathrm{~d}, J=9.2 \mathrm{~Hz}, 1 \mathrm{H}, 8^{\prime \prime}-\mathrm{H}\right) ;{ }^{13} \mathrm{C}$ NMR $(100.6$ $\left.\mathrm{MHz}, \mathrm{CD}_{3} \mathrm{OD}\right) \delta 21.7\left(\mathrm{CH}_{2}, \mathrm{C} 3^{\prime \prime}\right), 22.4\left(\mathrm{CH}_{2}, \mathrm{C} 4\right), 22.8\left(\mathrm{CH}_{2}\right.$, $\left.\mathrm{C2}^{\prime \prime}\right)$, $24.6\left(\mathrm{CH}_{3}, 2-\mathrm{CH}_{3}\right), 24.7\left(\mathrm{CH}_{2}, \mathrm{Cl}^{\prime \prime}\right), 27.6\left(\mathrm{CH}_{2}, \mathrm{C}^{\prime}\right), 27.8$ $\left(\mathrm{CH}_{2}, \mathrm{C6}^{\prime}\right), 29.3\left(\mathrm{CH}_{2}, \mathrm{C}^{\prime \prime}\right), 30.1\left(\mathrm{CH}_{2}\right), 30.2\left(\mathrm{CH}_{2}\right)\left(\mathrm{C}^{\prime}, \mathrm{C}^{\prime}\right)$, $30.38\left(\mathrm{CH}_{2}\right), 30.42\left(\mathrm{CH}_{2}\right)\left(\mathrm{C2}^{\prime}, \mathrm{C}^{\prime}\right), 31.3\left(\mathrm{CH}_{2}, \mathrm{C} 8^{\prime}\right), 32.3\left(\mathrm{CH}_{2}\right.$, C3), $40.2\left(\mathrm{CH}_{2}, \mathrm{Cl}^{\prime}\right), 47.4\left(\mathrm{CH}_{2}, 2-\mathrm{CH}_{2}-\mathrm{CO}\right), 49.3\left(\mathrm{CH}_{2}, \mathrm{C} 9^{\prime}\right), 56.4$ $\left(\mathrm{CH}_{3}, 7-\mathrm{OCH}_{3}\right), 75.6(\mathrm{C}, \mathrm{C} 2), 102.2(\mathrm{CH}, \mathrm{C} 8), 113.31\left(\mathrm{C}, \mathrm{C}^{\prime \prime} \mathrm{a}^{\prime \prime}\right.$, 113.35 (C, C4a), 115.4 (C, C8a"), $116.1(\mathrm{CH}, \mathrm{C} 5), 119.1(\mathrm{CH}$, $\left.\mathrm{C5}^{\prime \prime}\right), 126.7$ (CH, C7"), 128.8 (CH, C8"), 140.1 (C, C6"), 140.5 (C, C10a"), 141.1 (C, C6), 147.4 (C, C8a), 148.3 (C, C7), 152.0 (C,

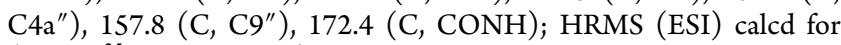
$\left(\mathrm{C}_{35} \mathrm{H}_{46}{ }^{35} \mathrm{ClN}_{3} \mathrm{O}_{4}+\mathrm{H}^{+}\right): 608.3250$, found 608.3243; HPLC purity $99 \%$.

$N$-\{8-[(6-Chloro-1,2,3,4-tetrahydroacridin-9-yl)amino]-3,6-dioxaoctyl\}-2-(6-hydroxy-7-methoxy-2-methylchroman-2-yl)acetamide (4d). It was prepared as described for 4a. From carboxylic acid 7 (130 $\mathrm{mg}, 0.52 \mathrm{mmol})$ and amine $10 \mathrm{~d}(206 \mathrm{mg}, 0.57 \mathrm{mmol})$, a brown sticky solid $(617 \mathrm{mg})$ was obtained and subjected to column chromatography purification $\left(35-70 \mu \mathrm{m}\right.$ silica gel, hexane/EtOAc/ $/ \mathrm{Et}_{3} \mathrm{~N}$ mixtures, gradient elution). On elution with hexane/EtOAc/Et ${ }_{3} \mathrm{~N}$ 10:90:0.2 to 0:100:0.2, amide $4 \mathrm{~d}$ ( $281 \mathrm{mg}, 91 \%$ yield) was isolated as a light brown sticky solid; $R_{f} 0.79\left(\mathrm{CH}_{2} \mathrm{Cl}_{2} / \mathrm{MeOH} / 50 \%\right.$ aq $\mathrm{NH}_{4} \mathrm{OH}$ 95:5:1).

4d.HCl: brown solid; mp 55-57 ${ }^{\circ} \mathrm{C}$; IR (ATR) $\nu$ 3600-2400 ( $\max$ at $3362,3250,3068,2921,2860, \mathrm{~N}-\mathrm{H}, \mathrm{N}^{+}-\mathrm{H}, \mathrm{O}-\mathrm{H}, \mathrm{C}-\mathrm{H}$ st), 1630, 1572, 1509 ( $\mathrm{C}=\mathrm{O}, \mathrm{Ar}-\mathrm{C}-\mathrm{C}, \mathrm{Ar}-\mathrm{C}-\mathrm{N}$ st $) \mathrm{cm}^{-1}$; ${ }^{1} \mathrm{H}$ NMR $\left(400 \mathrm{MHz}, \mathrm{CD}_{3} \mathrm{OD}\right) \delta 1.28\left(\mathrm{~s}, 3 \mathrm{H}, 2-\mathrm{CH}_{3}\right), 1.68\left(\mathrm{dt}, J=13.6 \mathrm{~Hz}, J^{\prime}\right.$ $\left.=6.8 \mathrm{~Hz}, 1 \mathrm{H}, 3-\mathrm{H}_{\mathrm{A}}\right), 1.81\left(\mathrm{dt}, J=13.6 \mathrm{~Hz}, J^{\prime}=6.8 \mathrm{~Hz}, 1 \mathrm{H}, 3-\mathrm{H}_{\mathrm{B}}\right)$, 1.89-2.00 (complex signal, 4H, 2"- $\left.\mathrm{H}_{2}, 3^{\prime \prime}-\mathrm{H}_{2}\right), 2.36(\mathrm{~d}, J=13.6 \mathrm{~Hz}$, $\left.1 \mathrm{H}, 2-\mathrm{CH}_{\mathrm{A}}-\mathrm{CO}\right), 2.46\left(\mathrm{~d}, J=13.6 \mathrm{~Hz}, 1 \mathrm{H}, 2-\mathrm{CH}_{\mathrm{B}}-\mathrm{CO}\right), 2.53(\mathrm{t}, J=$ $\left.6.8 \mathrm{~Hz}, 2 \mathrm{H}, 4-\mathrm{H}_{2}\right), 2.63\left(\mathrm{t}, J=6.0 \mathrm{~Hz}, 2 \mathrm{H}, 1^{\prime \prime}-\mathrm{H}_{2}\right), 2.98(\mathrm{t}, J=5.6 \mathrm{~Hz}$, $\left.2 \mathrm{H}, 4^{\prime \prime}-\mathrm{H}_{2}\right), 3.33\left(\mathrm{dt}, J=14.0 \mathrm{~Hz}, J^{\prime}=5.2 \mathrm{~Hz}, 1 \mathrm{H}, 1^{\prime}-\mathrm{H}_{\mathrm{A}}\right), 3.40(\mathrm{dt}, J$ $\left.=14.0 \mathrm{~Hz}, J^{\prime}=5.2 \mathrm{~Hz}, 1 \mathrm{H}, 1^{\prime}-\mathrm{H}_{\mathrm{B}}\right), 3.53\left(\mathrm{t}, J=5.2 \mathrm{~Hz}, 2 \mathrm{H}, 2^{\prime}-\mathrm{H}_{2}\right)$, $3.62(\mathrm{~m}, 2 \mathrm{H}), 3.66(\mathrm{~m}, 2 \mathrm{H})\left(4^{\prime}-\mathrm{H}_{2}, 5^{\prime}-\mathrm{H}_{2}\right), 3.71\left(\mathrm{~s}, 3 \mathrm{H}, 7-\mathrm{OCH}_{3}\right)$, $3.84\left(\mathrm{t}, J=5.2 \mathrm{~Hz}, 2 \mathrm{H}, 7^{\prime}-\mathrm{H}_{2}\right), 4.10\left(\mathrm{t}, J=5.2 \mathrm{~Hz}, 2 \mathrm{H}, 8^{\prime}-\mathrm{H}_{2}\right), 4.85(\mathrm{~s}$, $\left.\mathrm{NH},{ }^{+} \mathrm{NH}, \mathrm{OH}\right), 6.33(\mathrm{~s}, 1 \mathrm{H}, 8-\mathrm{H}), 6.35(\mathrm{~s}, 1 \mathrm{H}, 5-\mathrm{H}), 7.52(\mathrm{dd}, J=$ $\left.9.2 \mathrm{~Hz}, J^{\prime}=2.0 \mathrm{~Hz}, 1 \mathrm{H}, 7^{\prime \prime}-\mathrm{H}\right), 7.74\left(\mathrm{~d}, J=2.0 \mathrm{~Hz}, 1 \mathrm{H}, 5^{\prime \prime}-\mathrm{H}\right), 8.41$ $\left(\mathrm{d}, J=9.2 \mathrm{~Hz}, 1 \mathrm{H}, 8^{\prime \prime}-\mathrm{H}\right) ;{ }^{13} \mathrm{C}$ NMR $\left(100.6 \mathrm{MHz}, \mathrm{CD}_{3} \mathrm{OD}\right) \delta 21.7$ $\left(\mathrm{CH}_{2}, \mathrm{C}^{\prime \prime}\right), 22.2\left(\mathrm{CH}_{2}, \mathrm{C} 4\right), 22.7\left(\mathrm{CH}_{2}, \mathrm{C} 2 "\right), 24.4\left(\mathrm{CH}_{3}+\mathrm{CH}_{2}, 2-\right.$ $\left.\mathrm{CH}_{3}, \mathrm{Cl}^{\prime \prime}\right), 29.3\left(\mathrm{CH}_{2}, \mathrm{C}^{\prime \prime}\right), 32.6\left(\mathrm{CH}_{2}, \mathrm{C} 3\right), 40.2\left(\mathrm{CH}_{2}, \mathrm{Cl}^{\prime}\right), 46.7$ $\left(\mathrm{CH}_{2}, 2-\mathrm{CH}_{2}-\mathrm{CO}\right), 49.3\left(\mathrm{CH}_{2}, \mathrm{C}^{\prime}\right), 56.5\left(\mathrm{CH}_{3}, 7-\mathrm{OCH}_{3}\right), 70.2$ $\left(\mathrm{CH}_{2}, \mathrm{C}^{\prime}\right), 70.4\left(\mathrm{CH}_{2}, \mathrm{C}^{\prime}\right), 71.0\left(\mathrm{CH}_{2}\right), 71.3\left(\mathrm{CH}_{2}\right)\left(\mathrm{C4}^{\prime}, \mathrm{C5}^{\prime}\right)$, 75.4 (C, C2), 102.5 ( $\mathrm{CH}, \mathrm{C} 8), 113.4$ (C, C4a), 113.6 (C, C9a"), $115.6\left(\mathrm{C}, \mathrm{C} 8 \mathrm{a}^{\prime \prime}\right), 116.0(\mathrm{CH}, \mathrm{C} 5), 119.1(\mathrm{CH}, \mathrm{C} 5 "), 126.7(\mathrm{CH}$, $\left.\mathrm{C}^{\prime \prime}\right), 128.9\left(\mathrm{CH}, \mathrm{C} 8^{\prime \prime}\right), 140.0$ (C, C6"), 140.4 (C, C10a"), 141.2 (C, C6), 146.9 (C, C8a), 148.2 (C, C7), 152.3 (C, C4a"), 158.3 (C, C9"), 172.7 (C, CONH); HRMS (ESI) calcd for $\left(\mathrm{C}_{32} \mathrm{H}_{40}{ }^{35} \mathrm{ClN}_{3} \mathrm{O}_{6}+\right.$ $\left.\mathrm{H}^{+}\right)$: 598.2678, found 598.2692; HPLC purity $96 \%$.

7-[(6-Chloro-1,2,3,4-tetrahydroacridin-9-yl)amino]-N-[2-(6-hydroxy-7-methoxy-2-methylchroman-2-yl)ethyl]heptanamide (5a). To a solution of nitrile 13a (462 mg, $1.35 \mathrm{mmol})$ in $\mathrm{MeOH}(2$ $\mathrm{mL})$, a $40 \%$ methanolic solution of $\mathrm{KOH}(3.7 \mathrm{~mL})$ was added. The resulting suspension was stirred under reflux for $3 \mathrm{~h}$, then treated with $\mathrm{H}_{2} \mathrm{O}(4.7 \mathrm{~mL})$, and stirred under reflux overnight. The resulting solution was cooled to $\mathrm{rt}$ and evaporated under reduced pressure. The residue was treated with $\mathrm{HCl} /$ dioxane $(4 \mathrm{M}, 6.8 \mathrm{~mL})$, and the solution was concentrated in vacuo to give crude 7-[(6-chloro-1,2,3,4tetrahydroacridin-9-yl)amino]heptanoic acid, in the form of hydrochloride salt, as a yellow solid ( $2.46 \mathrm{~g})$, which was used in the following step without further purification.

From this crude carboxylic acid, the target amide 5a was prepared as described for 4a. From crude carboxylic acid $(2.46 \mathrm{~g})$ and amine 14 $(159 \mathrm{mg}, 0.68 \mathrm{mmol})$, a brown sticky solid $(3.30 \mathrm{~g})$ was obtained and subjected to column chromatography purification $(35-70 \mu \mathrm{m}$ silica gel, hexane/EtOAc/ $/ \mathrm{Et}_{3} \mathrm{~N}$ mixtures, gradient elution). On elution with hexane/EtOAc/ $/ \mathrm{Et}_{3} \mathrm{~N}$ 0:100:0.2, amide 5 a (337 mg, $87 \%$ overall yield) was isolated as a light yellow solid; $R_{f} 0.57\left(\mathrm{CH}_{2} \mathrm{Cl}_{2} / \mathrm{MeOH} / 50 \%\right.$ aq $\mathrm{NH}_{4} \mathrm{OH}$ 95:5:1).

5a.HCl: yellow solid; mp $121-123{ }^{\circ} \mathrm{C}$; IR (ATR) $\nu$ 3600-2400 ( $\max$ at $3245,3068,2926,2850, \mathrm{~N}-\mathrm{H}, \mathrm{N}^{+}-\mathrm{H}, \mathrm{O}-\mathrm{H}, \mathrm{C}-\mathrm{H}$ st), 1630, 1572, 1509 (C=O, Ar-C-C, Ar-C-N st) $\mathrm{cm}^{-1}$; ${ }^{1} \mathrm{H}$ NMR (400 $\left.\mathrm{MHz}, \mathrm{CD}_{3} \mathrm{OD}\right) \delta 1.25\left(\mathrm{~s}, 3 \mathrm{H}, 2^{\prime \prime}-\mathrm{CH}_{3}\right)$, superimposed in part 1.35 $\left(\mathrm{tt}, J=J^{\prime}=7.2 \mathrm{~Hz}, 2 \mathrm{H}\right), 1.43\left(\mathrm{tt}, J=J^{\prime}=7.2 \mathrm{~Hz}, 2 \mathrm{H}\right)\left(4-\mathrm{H}_{2}, 5-\mathrm{H}_{2}\right)$, $1.59\left(\mathrm{tt}, J=J^{\prime}=7.2 \mathrm{~Hz}, 2 \mathrm{H}, 3-\mathrm{H}_{2}\right), 1.70\left(\mathrm{dt}, J=13.6 \mathrm{~Hz}, J^{\prime}=6.8 \mathrm{~Hz}\right.$, $1 \mathrm{H}, 3^{\prime \prime}-\mathrm{H}_{\mathrm{A}}$ ), $1.72-1.86$ (complex signal, $5 \mathrm{H}, 6-\mathrm{H}_{2}, 2^{\prime \prime}-\mathrm{CH}_{2}, 3^{\prime \prime}-\mathrm{H}_{\mathrm{B}}$ ), $1.90-2.00$ (complex signal, $\left.4 \mathrm{H}, 2^{\prime}-\mathrm{H}_{2}, 3^{\prime}-\mathrm{H}_{2}\right), 2.16(\mathrm{t}, J=7.2 \mathrm{~Hz}, 2 \mathrm{H}$, $\left.2-\mathrm{H}_{2}\right), 2.60\left(\mathrm{t}, J=6.8 \mathrm{~Hz}, 2 \mathrm{H}, 4^{\prime \prime}-\mathrm{H}_{2}\right), 2.66\left(\right.$ br t, $J=5.6 \mathrm{~Hz}, 2 \mathrm{H}, 1^{\prime}-$ $\left.\mathrm{H}_{2}\right), 2.99\left(\mathrm{br} \mathrm{t}, J=5.6 \mathrm{~Hz}, 2 \mathrm{H}, 4^{\prime}-\mathrm{H}_{2}\right), 3.27\left(\mathrm{ddd}, J=13.2 \mathrm{~Hz}, J^{\prime}=9.2\right.$ $\left.\mathrm{Hz}, J^{\prime \prime}=6.0 \mathrm{~Hz}, 1 \mathrm{H}, \mathrm{CH}_{A^{-}} \mathrm{NHCO}\right), 3.39\left(\mathrm{ddd}, J=13.2 \mathrm{~Hz}, J^{\prime}=9.2\right.$ $\left.\mathrm{Hz}, \mathrm{J}^{\prime \prime}=6.0 \mathrm{~Hz}, 1 \mathrm{H}, \mathrm{CH}_{B}-\mathrm{NHCO}\right), 3.74\left(\mathrm{~s}, 3 \mathrm{H}, 7^{\prime \prime}-\mathrm{OCH}_{3}\right), 3.90(\mathrm{t}, J$ $\left.=7.2 \mathrm{~Hz}, 2 \mathrm{H}, 7-\mathrm{H}_{2}\right), 4.86\left(\mathrm{~s}, \mathrm{NH},{ }^{+} \mathrm{NH}, \mathrm{OH}\right), 6.30\left(\mathrm{~s}, 1 \mathrm{H}, 8^{\prime \prime}-\mathrm{H}\right)$, $6.42\left(\mathrm{~s}, 1 \mathrm{H}, 5^{\prime \prime}-\mathrm{H}\right), 7.55\left(\mathrm{dd}, J=9.2 \mathrm{~Hz}, J^{\prime}=2.0 \mathrm{~Hz}, 1 \mathrm{H}, 7^{\prime}-\mathrm{H}\right), 7.76$ $\left(\mathrm{d}, J=2.0 \mathrm{~Hz}, 1 \mathrm{H}, 5^{\prime}-\mathrm{H}\right), 8.36\left(\mathrm{~d}, J=9.2 \mathrm{~Hz}, 1 \mathrm{H}, 8^{\prime}-\mathrm{H}\right) ;{ }^{13} \mathrm{C}$ NMR $\left(100.6 \mathrm{MHz}, \mathrm{CD}_{3} \mathrm{OD}\right) \delta 21.7\left(\mathrm{CH}_{2}, \mathrm{C}^{\prime}\right), 22.3\left(\mathrm{CH}_{2}, \mathrm{C}^{\prime \prime}\right), 22.8$ $\left(\mathrm{CH}_{2}, \mathrm{C}^{\prime}\right), 24.3\left(\mathrm{CH}_{3}, 2^{\prime \prime}-\mathrm{CH}_{3}\right), 24.7\left(\mathrm{CH}_{2}, \mathrm{Cl}^{\prime}\right), 26.7\left(\mathrm{CH}_{2}, \mathrm{C} 3\right)$, $27.4\left(\mathrm{CH}_{2}, \mathrm{C5}\right), 29.3\left(\mathrm{CH}_{2}, \mathrm{C}^{\prime}\right), 29.7\left(\mathrm{CH}_{2}, \mathrm{C} 4\right), 31.1\left(\mathrm{CH}_{2}, \mathrm{C} 6\right)$, $32.6\left(\mathrm{CH}_{2}, \mathrm{C}^{\prime \prime}\right), 35.9\left(\mathrm{CH}_{2}, \mathrm{CH}_{2}-\mathrm{NHCO}\right), 36.9\left(\mathrm{CH}_{2}, \mathrm{C} 2\right), 39.4$ 
$\left(\mathrm{CH}_{2}, 2^{\prime \prime}-\mathrm{CH}_{2}\right), 49.1\left(\mathrm{CH}_{2}, \mathrm{C} 7\right), 56.3\left(\mathrm{CH}_{3}, 7^{\prime \prime}-\mathrm{OCH}_{3}\right), 75.8(\mathrm{C}$, $\left.\mathrm{C} 2^{\prime \prime}\right), 102.2\left(\mathrm{CH}, \mathrm{C} 8^{\prime \prime}\right), 113.3\left(\mathrm{C}, \mathrm{C} 9 \mathrm{a}^{\prime}\right), 113.4\left(\mathrm{C}, \mathrm{C} 4 \mathrm{a}^{\prime \prime}\right), 115.4(\mathrm{C}$,

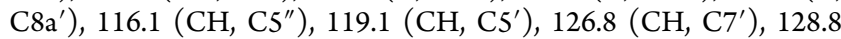
(CH, C8'), 140.1 (C, $\left.6^{\prime}\right), 140.5$ (C, $\left.\mathrm{C1}^{\prime} \mathrm{a}^{\prime}\right), 140.8$ (C, C6"), 147.7 (C, C8a"), 148.3 (C, C7"), 152.0 (C, C4a'), 157.8 (C, C9'), 175.9 (C, C1); HRMS (ESI) calcd for $\left(\mathrm{C}_{33} \mathrm{H}_{42}{ }^{35} \mathrm{ClN}_{3} \mathrm{O}_{4}+\mathrm{H}^{+}\right)$: 580.2937, found 580.2946; HPLC purity $96 \%$.

8-[(6-Chloro-1,2,3,4-tetrahydroacridin-9-yl)amino]-N-[2-(6-hydroxy-7-methoxy-2-methylchroman-2-yl)ethyl]octanamide (5b). It was prepared as described for 5a. From nitrile 13b (367 mg, 1.03 $\mathrm{mmol})$, crude 8-[(6-chloro-1,2,3,4-tetrahydroacridin-9-yl)amino]octanoic acid, in the form of hydrochloride salt, was obtained as a yellow solid $(1.93 \mathrm{~g})$ and used in the following step without further purification. From crude carboxylic acid $(1.93 \mathrm{~g})$ and amine 14 (100 $\mathrm{mg}, 0.43 \mathrm{mmol})$, a brown sticky solid $(2.29 \mathrm{~g})$ was obtained and subjected to column chromatography purification $(35-70 \mu \mathrm{m}$ silica gel, hexane/EtOAc/ $\mathrm{Et}_{3} \mathrm{~N}$ mixtures, gradient elution). On elution with hexane/EtOAc/ $\mathrm{Et}_{3} \mathrm{~N}$ 20:80:0.2, amide 5 b (139 mg, 55\% overall yield) was isolated as a yellow solid; $R_{f} 0.67\left(\mathrm{CH}_{2} \mathrm{Cl}_{2} / \mathrm{MeOH} / 50 \%\right.$ aq $\mathrm{NH}_{4} \mathrm{OH}$ 95:5:1).

5b·HCl: yellow solid; mp $72-74{ }^{\circ} \mathrm{C}$; IR (ATR) $\nu$ 3600-2200 ( $\max$ at $3245,3063,2921,2850, \mathrm{~N}-\mathrm{H}, \mathrm{N}^{+}-\mathrm{H}, \mathrm{O}-\mathrm{H}, \mathrm{C}-\mathrm{H}$ st), 1630, 1572, $1509(\mathrm{C}=\mathrm{O}, \mathrm{Ar}-\mathrm{C}-\mathrm{C}, \mathrm{Ar}-\mathrm{C}-\mathrm{N} \mathrm{st}) \mathrm{cm}^{-1} ;{ }^{1} \mathrm{H}$ NMR $(400$ $\left.\mathrm{MHz}, \mathrm{CD}_{3} \mathrm{OD}\right) \delta 1.25\left(\mathrm{~s}, 3 \mathrm{H}, 2^{\prime \prime}-\mathrm{CH}_{3}\right.$ ), 1.28-1.44 (complex signal, $\left.6 \mathrm{H}, 4-\mathrm{H}_{2}, 5-\mathrm{H}_{2}, 6-\mathrm{H}_{2}\right), 1.57\left(\mathrm{tt}, J=J^{\prime}=7.2 \mathrm{~Hz}, 2 \mathrm{H}, 3-\mathrm{H}_{2}\right), 1.69(\mathrm{dt}, J$ $\left.=13.2 \mathrm{~Hz}, J^{\prime}=6.4 \mathrm{~Hz}, 1 \mathrm{H}, 3^{\prime \prime}-\mathrm{H}_{\mathrm{A}}\right), 1.71-1.86($ complex signal, $5 \mathrm{H}$, 7- $\mathrm{H}_{2}, 2^{\prime \prime}-\mathrm{CH}_{2}, 3^{\prime \prime}-\mathrm{H}_{\mathrm{B}}$ ), 1.92-2.00 (complex signal, $4 \mathrm{H}, 2^{\prime}-\mathrm{H}_{2}, 3^{\prime}-\mathrm{H}_{2}$ ), $2.16\left(\mathrm{t}, J=7.2 \mathrm{~Hz}, 2 \mathrm{H}, 2-\mathrm{H}_{2}\right), 2.61\left(\mathrm{t}, J=6.4 \mathrm{~Hz}, 2 \mathrm{H}, 4^{\prime \prime}-\mathrm{H}_{2}\right), 2.66$ (br t, $\left.J=5.6 \mathrm{~Hz}, 2 \mathrm{H}, 1^{\prime}-\mathrm{H}_{2}\right), 2.99$ (br t, $J=5.6 \mathrm{~Hz}, 2 \mathrm{H}, 4^{\prime}-\mathrm{H}_{2}$ ), 3.29 (ddd, $J=13.6 \mathrm{~Hz}, J^{\prime}=8.8 \mathrm{~Hz}, J^{\prime \prime}=6.4 \mathrm{~Hz}, 1 \mathrm{H}, \mathrm{CH}_{A}-\mathrm{NHCO}$ ), 3.40 (ddd, $J=13.6 \mathrm{~Hz}, J^{\prime}=9.2 \mathrm{~Hz}, J^{\prime \prime}=6.0 \mathrm{~Hz}, 1 \mathrm{H}, \mathrm{CH}_{B}-\mathrm{NHCO}$ ), 3.75 $\left(\mathrm{s}, 3 \mathrm{H}, 7^{\prime \prime}-\mathrm{OCH}_{3}\right), 3.91\left(\mathrm{t}, J=7.2 \mathrm{~Hz}, 2 \mathrm{H}, 8-\mathrm{H}_{2}\right), 4.87\left(\mathrm{~s}, \mathrm{NH},{ }^{+} \mathrm{NH}\right.$, $\mathrm{OH}), 6.30\left(\mathrm{~s}, 1 \mathrm{H}, 8^{\prime \prime}-\mathrm{H}\right), 6.43\left(\mathrm{~s}, 1 \mathrm{H}, 5^{\prime \prime}-\mathrm{H}\right), 7.56\left(\mathrm{dd}, J=9.2 \mathrm{~Hz}, J^{\prime}\right.$ $\left.=2.0 \mathrm{~Hz}, 1 \mathrm{H}, 7^{\prime}-\mathrm{H}\right), 7.77\left(\mathrm{~d}, J=2.0 \mathrm{~Hz}, 1 \mathrm{H}, 5^{\prime}-\mathrm{H}\right), 8.37(\mathrm{~d}, J=9.2$ $\left.\mathrm{Hz}, 1 \mathrm{H}, 8^{\prime}-\mathrm{H}\right) ;{ }^{13} \mathrm{C}$ NMR $\left(100.6 \mathrm{MHz}, \mathrm{CD}_{3} \mathrm{OD}\right) \delta 21.8\left(\mathrm{CH}_{2}, \mathrm{C}^{\prime}\right)$, $22.3\left(\mathrm{CH}_{2}, \mathrm{C}^{\prime \prime}\right), 22.8\left(\mathrm{CH}_{2}, \mathrm{C} 2^{\prime}\right), 24.2\left(\mathrm{CH}_{3}, 2^{\prime \prime}-\mathrm{CH}_{3}\right), 24.7\left(\mathrm{CH}_{2}\right.$, $\left.\mathrm{C1}^{\prime}\right)$, $26.7\left(\mathrm{CH}_{2}, \mathrm{C} 3\right), 27.5\left(\mathrm{CH}_{2}, \mathrm{C} 6\right), 29.3\left(\mathrm{CH}_{2}, \mathrm{C} 4^{\prime}\right), 29.9\left(\mathrm{CH}_{2}\right)$, $30.0\left(\mathrm{CH}_{2}\right)(\mathrm{C} 4, \mathrm{C} 5), 31.4\left(\mathrm{CH}_{2}, \mathrm{C} 7\right), 32.6\left(\mathrm{CH}_{2}, \mathrm{C} 3^{\prime \prime}\right), 36.0\left(\mathrm{CH}_{2}\right.$, $\left.\mathrm{CH}_{2}-\mathrm{NHCO}\right), 37.0\left(\mathrm{CH}_{2}, \mathrm{C} 2\right), 39.4\left(\mathrm{CH}_{2}, 2^{\prime \prime}-\mathrm{CH}_{2}\right), 49.3\left(\mathrm{CH}_{2}, \mathrm{C} 8\right)$, $56.3\left(\mathrm{CH}_{3}, 7^{\prime \prime}-\mathrm{OCH}_{3}\right), 75.8\left(\mathrm{C}, \mathrm{C} 2^{\prime \prime}\right), 102.2\left(\mathrm{CH}, \mathrm{C} 8^{\prime \prime}\right), 113.3(\mathrm{C}$, C9a'), 113.4 (C, C4a"), $115.4\left(\mathrm{C}, \mathrm{C} 8 \mathrm{a}^{\prime}\right), 116.1\left(\mathrm{CH}, \mathrm{C} 5^{\prime \prime}\right), 119.1$ $\left(\mathrm{CH}, \mathrm{C5}^{\prime}\right), 126.8\left(\mathrm{CH}, \mathrm{C7}^{\prime}\right), 128.8\left(\mathrm{CH}, \mathrm{C}^{\prime}\right), 140.1\left(\mathrm{C}, \mathrm{C6}^{\prime}\right), 140.5$

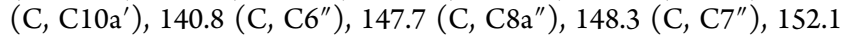
(C, C4a'), 157.8 (C, C9'), 176.1 (C, C1); HRMS (ESI) calcd for $\left(\mathrm{C}_{34} \mathrm{H}_{44}{ }^{35} \mathrm{ClN}_{3} \mathrm{O}_{4}+\mathrm{H}^{+}\right)$: 594.3093, found 594.3092; HPLC purity 97\%.

9-[(6-Chloro-1,2,3,4-tetrahydroacridin-9-yl)amino]-N-[2-(6-hydroxy-7-methoxy-2-methylchroman-2-yl)ethyl]nonanamide (5c). It was prepared as described for 5a. From nitrile 13c (315 mg, 0.85 $\mathrm{mmol})$, crude 9-[(6-chloro-1,2,3,4-tetrahydroacridin-9-yl)amino]nonanoic acid, in the form of hydrochloride salt, was obtained as a light yellow solid $(1.55 \mathrm{~g})$ and used in the following step without further purification. From crude carboxylic acid $(1.55 \mathrm{~g})$ and amine $14(133 \mathrm{mg}, 0.57 \mathrm{mmol})$, a brown oily residue $(2.21 \mathrm{~g})$ was obtained and subjected to column chromatography purification $(35-70 \mu \mathrm{m}$ silica gel, hexane $/ \mathrm{EtOAc} / \mathrm{Et}_{3} \mathrm{~N}$ mixtures, gradient elution). On elution with hexane/EtOAc/ $\mathrm{Et}_{3} \mathrm{~N}$ 10:90:0.2, amide $5 \mathrm{c}(189 \mathrm{mg}$, 52\% overall yield) was isolated as a light yellow solid; $R_{f} 0.69\left(\mathrm{CH}_{2} \mathrm{Cl}_{2} / \mathrm{MeOH} /\right.$ $50 \%$ aq $\mathrm{NH}_{4} \mathrm{OH}$ 95:5:1).

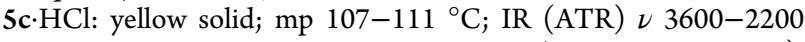
( $\max$ at $3314,3242,3057,2921,2849, \mathrm{~N}-\mathrm{H}, \mathrm{N}^{+}-\mathrm{H}, \mathrm{O}-\mathrm{H}, \mathrm{C}-\mathrm{H}$ st), 1625, 1571, 1518 (C=O, Ar-C-C, Ar-C-N st) cm ${ }^{-1}$; ${ }^{1} \mathrm{H}$ NMR $\left(400 \mathrm{MHz}, \mathrm{CD}_{3} \mathrm{OD}\right) \delta 1.26\left(\mathrm{~s}, 3 \mathrm{H}, 2^{\prime \prime}-\mathrm{CH}_{3}\right), 1.26-1.38$ (complex signal, $\left.6 \mathrm{H}, 4-\mathrm{H}_{2}, 5-\mathrm{H}_{2}, 6-\mathrm{H}_{2}\right)$, superimposed in part $1.42\left(\mathrm{tt}, J=J^{\prime}=\right.$ $\left.7.2 \mathrm{~Hz}, 2 \mathrm{H}, 7-\mathrm{H}_{2}\right), 1.57\left(\mathrm{tt}, J=J^{\prime}=7.2 \mathrm{~Hz}, 2 \mathrm{H}, 3-\mathrm{H}_{2}\right), 1.72(\mathrm{dt}, J=$ $13.6 \mathrm{~Hz}, J^{\prime}=6.8 \mathrm{~Hz}, 1 \mathrm{H}, 3^{\prime \prime}-\mathrm{H}_{\mathrm{A}}$ ), 1.74-1.87 (complex signal, $5 \mathrm{H}, 8$ $\mathrm{H}_{2}, 2^{\prime \prime}-\mathrm{CH}_{2}, 3^{\prime \prime}-\mathrm{H}_{\mathrm{B}}$ ), 1.91-2.00 (complex signal, $4 \mathrm{H}, 2^{\prime}-\mathrm{H}_{2}, 3^{\prime}-\mathrm{H}_{2}$ ), $2.16\left(\mathrm{t}, J=7.2 \mathrm{~Hz}, 2 \mathrm{H}, 2-\mathrm{H}_{2}\right), 2.61\left(\mathrm{t}, J=6.8 \mathrm{~Hz}, 2 \mathrm{H}, 4^{\prime \prime}-\mathrm{H}_{2}\right), 2.66$ (br t, $\left.J=6.0 \mathrm{~Hz}, 2 \mathrm{H}, 1^{\prime}-\mathrm{H}_{2}\right), 2.99$ (br t, $J=6.0 \mathrm{~Hz}, 2 \mathrm{H}, 4^{\prime}-\mathrm{H}_{2}$ ), 3.29 (ddd, $J=13.2 \mathrm{~Hz}, J^{\prime}=9.2 \mathrm{~Hz}, J^{\prime \prime}=6.4 \mathrm{~Hz}, 1 \mathrm{H}, \mathrm{CH}_{A^{-}} \mathrm{NHCO}$ ), 3.41 (ddd, $J=13.2 \mathrm{~Hz}, J^{\prime}=9.2 \mathrm{~Hz}, J^{\prime \prime}=6.4 \mathrm{~Hz}, 1 \mathrm{H}, \mathrm{CH}_{B}-\mathrm{NHCO}$ ), 3.75 $\left(\mathrm{s}, 3 \mathrm{H}, 7^{\prime \prime}-\mathrm{OCH}_{3}\right), 3.91\left(\mathrm{t}, J=7.2 \mathrm{~Hz}, 2 \mathrm{H}, 9-\mathrm{H}_{2}\right), 4.87\left(\mathrm{~s}, \mathrm{NH},{ }^{+} \mathrm{NH}\right.$, $\mathrm{OH}), 6.30\left(\mathrm{~s}, 1 \mathrm{H}, 8^{\prime \prime}-\mathrm{H}\right), 6.44\left(\mathrm{~s}, 1 \mathrm{H}, 5^{\prime \prime}-\mathrm{H}\right), 7.56\left(\mathrm{dd}, J=9.2 \mathrm{~Hz}, J^{\prime}\right.$ $\left.=2.4 \mathrm{~Hz}, 1 \mathrm{H}, 7^{\prime}-\mathrm{H}\right), 7.77\left(\mathrm{~d}, J=2.4 \mathrm{~Hz}, 1 \mathrm{H}, 5^{\prime}-\mathrm{H}\right), 8.37(\mathrm{~d}, J=9.2$ $\left.\mathrm{Hz}, 1 \mathrm{H}, 8^{\prime}-\mathrm{H}\right) ;{ }^{13} \mathrm{C}$ NMR $\left(100.6 \mathrm{MHz}, \mathrm{CD}_{3} \mathrm{OD}\right) \delta 21.8\left(\mathrm{CH}_{2}, \mathrm{C}^{\prime}\right)$, $22.3\left(\mathrm{CH}_{2}, \mathrm{C}^{\prime \prime}\right), 22.8\left(\mathrm{CH}_{2}, \mathrm{C} 2^{\prime}\right), 24.2\left(\mathrm{CH}_{3}, 2^{\prime \prime}-\mathrm{CH}_{3}\right), 24.7\left(\mathrm{CH}_{2}\right.$, $\left.\mathrm{C1}^{\prime}\right), 26.8\left(\mathrm{CH}_{2}, \mathrm{C} 3\right), 27.6\left(\mathrm{CH}_{2}, \mathrm{C} 7\right), 29.3\left(\mathrm{CH}_{2}, \mathrm{C}^{\prime}\right), 30.00$ $\left(\mathrm{CH}_{2}\right), 30.02\left(\mathrm{CH}_{2}\right), 30.1\left(\mathrm{CH}_{2}\right)(\mathrm{C} 4, \mathrm{C} 5, \mathrm{C} 6), 31.3\left(\mathrm{CH}_{2}, \mathrm{C} 8\right), 32.6$ $\left(\mathrm{CH}_{2}, \mathrm{C} 3 "\right)$, $36.1\left(\mathrm{CH}_{2}, \mathrm{CH}_{2}-\mathrm{NHCO}\right), 37.0\left(\mathrm{CH}_{2}, \mathrm{C} 2\right), 39.4\left(\mathrm{CH}_{2}\right.$, $\left.2^{\prime \prime}-\mathrm{CH}_{2}\right), 49.3\left(\mathrm{CH}_{2}, \mathrm{C} 9\right), 56.3\left(\mathrm{CH}_{3}, 7^{\prime \prime}-\mathrm{OCH}_{3}\right), 75.8\left(\mathrm{C}, \mathrm{C} 2^{\prime \prime}\right)$, $102.2\left(\mathrm{CH}, \mathrm{C} 8{ }^{\prime \prime}\right), 113.3$ (C, C9a'), 113.4 (C, C4a"), 115.4 (C, C8a'), $116.1\left(\mathrm{CH}, \mathrm{C5}^{\prime \prime}\right), 119.1\left(\mathrm{CH}, \mathrm{C5}^{\prime}\right), 126.8\left(\mathrm{CH}, \mathrm{C7}^{\prime}\right), 128.8(\mathrm{CH}$, C8'), 140.1 (C, C6'), 140.5 (C, C10a'), 140.8 (C, C6"), 147.7 (C, C8a"), 148.3 (C, C7"), 152.0 (C, C4a'), 157.8 (C, C9'), 176.2 (C, C1); HRMS (ESI) calcd for $\left(\mathrm{C}_{35} \mathrm{H}_{46}{ }^{35} \mathrm{ClN}_{3} \mathrm{O}_{4}+\mathrm{H}^{+}\right)$: 608.3250, found 608.3259; HPLC purity $99 \%$.

$N$-(6-Chloro-1,2,3,4-tetrahydroacridin-9-yl)- $N^{\prime}-[2-(6-h y d r o x y-7-$ methoxy-2-methylchroman-2-yl)ethyl]heptane-1,7-diamine (6a). A solution of tosylate $15(175 \mathrm{mg}, 0.44 \mathrm{mmol})$ in dry $\mathrm{CH}_{3} \mathrm{CN}(1.5$ $\mathrm{mL}$ ) was added to a suspension of amine $10 \mathrm{a}(461 \mathrm{mg}, 1.33 \mathrm{mmol})$ and anhyd $\mathrm{Et}_{3} \mathrm{~N}(0.07 \mathrm{~mL}, 51 \mathrm{mg}, 0.50 \mathrm{mmol})$ in dry $\mathrm{CH}_{3} \mathrm{CN}(2$ $\mathrm{mL})$. The reaction mixture was stirred at $80{ }^{\circ} \mathrm{C}$ for $48 \mathrm{~h}$ and then concentrated in vacuo to give a dark brown oil $(789 \mathrm{mg})$, which was purified by column chromatography $\left(35-70 \mu \mathrm{m}\right.$ silica gel, $\mathrm{CH}_{2} \mathrm{Cl}_{2} /$ $\mathrm{MeOH} / 50 \%$ aq $\mathrm{NH}_{4} \mathrm{OH}$ mixtures, gradient elution). On elution with $\mathrm{CH}_{2} \mathrm{Cl}_{2} / \mathrm{MeOH} / 50 \%$ aq $\mathrm{NH}_{4} \mathrm{OH}$ 99:1:0.4 to 98:2:0.4, amine 6a (61 $\mathrm{mg}, 24 \%$ yield $)$ was isolated as a beige solid; $R_{f} 0.76\left(\mathrm{CH}_{2} \mathrm{Cl}_{2} /\right.$ $\mathrm{MeOH} / 50 \%$ aq $\mathrm{NH}_{4} \mathrm{OH}$ 90:10:1).

A solution of $6 \mathrm{a}(37 \mathrm{mg}, 0.07 \mathrm{mmol})$ in $\mathrm{CH}_{2} \mathrm{Cl}_{2}(1 \mathrm{~mL})$ was filtered through a $0.2 \mu \mathrm{m}$ PTFE filter, treated with $\mathrm{HCl} / \mathrm{Et}_{2} \mathrm{O}(1.35 \mathrm{~N}$, $0.4 \mathrm{~mL}$ ), and evaporated under reduced pressure. The resulting solid was washed with pentane $(3 \times 2 \mathrm{~mL})$ to give, after drying at $40{ }^{\circ} \mathrm{C} / 30$ Torr for $48 \mathrm{~h}, 6 \mathrm{a} \cdot 2 \mathrm{HCl}(34 \mathrm{mg})$ as a beige solid: $\mathrm{mp} 160-163{ }^{\circ} \mathrm{C}$; IR (ATR) $\nu$ 3600-2200 ( $\max$ at 3240, 2930, 2852, 2780, 2604, 2496, $\mathrm{N}-\mathrm{H}, \mathrm{N}^{+}-\mathrm{H}, \mathrm{O}-\mathrm{H}, \mathrm{C}-\mathrm{H}$ st), 1628, 1573, 1509 (Ar-C-C, Ar-C$\mathrm{N}$ st) $\mathrm{cm}^{-1}$; ${ }^{1} \mathrm{H}$ NMR (400 MHz, $\left.\mathrm{CD}_{3} \mathrm{OD}\right) \delta 1.30\left(\mathrm{~s}, 3 \mathrm{H}, 2^{\prime \prime}-\mathrm{CH}_{3}\right)$, 1.39-1.51 (complex signal, 6H, 3- $\left.\mathrm{H}_{2}, 4-\mathrm{H}_{2}, 5-\mathrm{H}_{2}\right), 1.71(\mathrm{~m}, 2 \mathrm{H}, 6-$ $\left.\mathrm{H}_{2}\right)$, superimposed in part $1.80\left(\mathrm{dt}, J=13.6 \mathrm{~Hz}, J^{\prime}=6.8 \mathrm{~Hz}, 1 \mathrm{H}, 3^{\prime \prime}\right.$ $\mathrm{H}_{\mathrm{A}}$ ), $1.82-1.88$ (complex signal, $3 \mathrm{H}, 2-\mathrm{H}_{2}, 3^{\prime \prime}-\mathrm{H}_{\mathrm{B}}$ ), $1.90-2.00$ (complex signal, $\left.5 \mathrm{H}, 2^{\prime}-\mathrm{H}_{2}, 3^{\prime}-\mathrm{H}_{2}, 2^{\prime \prime}-\mathrm{CH}_{\mathrm{A}}-\mathrm{CH}_{2}-\mathrm{NH}\right), 2.07(\mathrm{dt}, J=$ $14.4 \mathrm{~Hz}, \mathrm{~J}^{\prime}=6.8 \mathrm{~Hz}, 1 \mathrm{H}, 2^{\prime \prime}-\mathrm{CH}_{\mathrm{B}}-\mathrm{CH}_{2}-\mathrm{NH}$ ), 2.64-2.72 (complex signal, $4 \mathrm{H}, 1^{\prime}-\mathrm{H}_{2}, 4^{\prime \prime}-\mathrm{H}_{2}$ ), 2.97-3.05 (complex signal, 4H, 7- $\mathrm{H}_{2}, 4^{\prime}$ $\left.\mathrm{H}_{2}\right), 3.21\left(\mathrm{t}, J=7.6 \mathrm{~Hz}, 2 \mathrm{H}, 2^{\prime \prime}-\mathrm{CH}_{2}-\mathrm{CH}_{2}-\mathrm{NH}\right), 3.76\left(\mathrm{~s}, 3 \mathrm{H}, 7^{\prime \prime}-\right.$ $\left.\mathrm{OCH}_{3}\right), 3.94\left(\mathrm{t}, J=7.6 \mathrm{~Hz}, 2 \mathrm{H}, 1-\mathrm{H}_{2}\right), 4.86\left(\mathrm{~s}, \mathrm{NH},{ }^{+} \mathrm{NH},{ }^{+} \mathrm{NH}_{2}\right.$, $\mathrm{OH}), 6.35\left(\mathrm{~s}, 1 \mathrm{H}, 8^{\prime \prime}-\mathrm{H}\right), 6.48\left(\mathrm{~s}, 1 \mathrm{H}, 5^{\prime \prime}-\mathrm{H}\right), 7.56\left(\mathrm{dd}, J=9.2 \mathrm{~Hz}, J^{\prime}\right.$ $\left.=1.6 \mathrm{~Hz}, 1 \mathrm{H}, 7^{\prime}-\mathrm{H}\right), 7.79\left(\mathrm{~d}, J=1.6 \mathrm{~Hz}, 1 \mathrm{H}, 5^{\prime}-\mathrm{H}\right), 8.39(\mathrm{~d}, J=9.2$ $\left.\mathrm{Hz}, 1 \mathrm{H}, 8^{\prime}-\mathrm{H}\right) ;{ }^{13} \mathrm{C} \mathrm{NMR}\left(100.6 \mathrm{MHz}, \mathrm{CD}_{3} \mathrm{OD}\right) \delta 21.7\left(\mathrm{CH}_{2}, \mathrm{C}^{\prime}\right)$, $22.2\left(\mathrm{CH}_{2}, \mathrm{C}^{\prime \prime}\right), 22.9\left(\mathrm{CH}_{2}, \mathrm{C} 2^{\prime}\right), 23.7\left(\mathrm{CH}_{3}, 2^{\prime \prime}-\mathrm{CH}_{3}\right), 24.8\left(\mathrm{CH}_{2}\right.$, $\left.\mathrm{Cl}^{\prime}\right)$, $27.2\left(\mathrm{CH}_{2}, \mathrm{C} 6\right), 27.4\left(\mathrm{CH}_{2}\right), 27.5\left(\mathrm{CH}_{2}\right)(\mathrm{C} 3, \mathrm{C} 5), 29.3\left(\mathrm{CH}_{2}\right.$, $\left.\mathrm{C}^{\prime}\right), 29.7\left(\mathrm{CH}_{2}, \mathrm{C} 4\right), 31.3\left(\mathrm{CH}_{2}, \mathrm{C} 2\right), 32.6\left(\mathrm{CH}_{2}, \mathrm{C} 3{ }^{\prime \prime}\right), 36.4\left(\mathrm{CH}_{2}\right.$, $\left.2^{\prime \prime}-\mathrm{CH}_{2}-\mathrm{CH}_{2}-\mathrm{NH}\right)$, $44.7\left(\mathrm{CH}_{2}, 2^{\prime \prime}-\mathrm{CH}_{2}-\mathrm{CH}_{2}-\mathrm{NH}\right), 48.9\left(\mathrm{CH}_{2}, \mathrm{C} 7\right)$, $49.1\left(\mathrm{CH}_{2}, \mathrm{C} 1\right), 56.4\left(\mathrm{CH}_{3}, 7^{\prime \prime}-\mathrm{OCH}_{3}\right), 75.3(\mathrm{C}, \mathrm{C} 2 "), 102.2(\mathrm{CH}$, C8"), $113.32(\mathrm{C}), 113.34(\mathrm{C})\left(\mathrm{C} 9 \mathrm{a}^{\prime}, \mathrm{C} 4 \mathrm{a}^{\prime \prime}\right), 115.4\left(\mathrm{C}, \mathrm{C} 8 \mathrm{a}^{\prime}\right), 116.2$ $\left(\mathrm{CH}, \mathrm{C5}^{\prime \prime}\right), 119.1\left(\mathrm{CH}, \mathrm{C5}^{\prime}\right), 126.8\left(\mathrm{CH}, \mathrm{C}^{\prime}\right), 128.8\left(\mathrm{CH}, \mathrm{C}^{\prime}\right)$, 140.0 (C, C6'), 140.5 (C, C10a'), 141.3 (C, C6"), 147.2 (C, C8a"), 148.4 (C, C7"), 152.1 (C, C4a'), 157.8 (C, C9'); HRMS (ESI) calcd for $\left(\mathrm{C}_{33} \mathrm{H}_{44}{ }^{35} \mathrm{ClN}_{3} \mathrm{O}_{3}+\mathrm{H}^{+}\right): 566.3144$, found 566.3138 ; HPLC purity $98 \%$.

$N$-(6-Chloro-1,2,3,4-tetrahydroacridin-9-yl)- $N^{\prime}-[2-(6-h y d r o x y-7-$ methoxy-2-methylchroman-2-yl)ethyl]octane-1,8-diamine (6b). It was prepared as described for 6a. From tosylate 15 (170 mg, 0.43 $\mathrm{mmol})$ and amine $10 \mathrm{~b}(467 \mathrm{mg}, 1.30 \mathrm{mmol})$, a brown oily residue $(678 \mathrm{mg}$ ) was obtained and subjected to column chromatography purification $\left(35-70 \mu \mathrm{m}\right.$ silica gel, $\mathrm{CH}_{2} \mathrm{Cl}_{2} / \mathrm{MeOH} / 50 \%$ aq $\mathrm{NH}_{4} \mathrm{OH}$ mixtures, gradient elution). On elution with $\mathrm{CH}_{2} \mathrm{Cl}_{2} / \mathrm{MeOH} / 50 \%$ aq $\mathrm{NH}_{4} \mathrm{OH} 99: 1: 0.4$, amine $6 \mathbf{b}$ (143 mg, 57\% yield) was isolated as a beige solid; $R_{f} 0.74\left(\mathrm{CH}_{2} \mathrm{Cl}_{2} / \mathrm{MeOH} / 50 \%\right.$ aq $\mathrm{NH}_{4} \mathrm{OH}$ 90:10:1).

6b $2 \mathrm{HCl}$ : light yellow solid; mp $147-149^{\circ} \mathrm{C}$; IR (ATR) $\nu 3600-$ 2200 ( $\max$ at $3240,2930,2852,2780, \mathrm{~N}-\mathrm{H}, \mathrm{N}^{+}-\mathrm{H}, \mathrm{O}-\mathrm{H}, \mathrm{C}-\mathrm{H}$ st), 1630, 1573, 1511 (Ar-C-C, Ar-C-N st) $\mathrm{cm}^{-1} ;{ }^{1} \mathrm{H}$ NMR (400 
$\left.\mathrm{MHz}, \mathrm{CD}_{3} \mathrm{OD}\right) \delta 1.30$ (s, 3H, 2"- $\mathrm{CH}_{3}$ ), 1.36-1.52 (complex signal, $\left.8 \mathrm{H}, 3-\mathrm{H}_{2}, 4-\mathrm{H}_{2}, 5-\mathrm{H}_{2}, 6-\mathrm{H}_{2}\right), 1.69\left(\mathrm{~m}, 2 \mathrm{H}, 7-\mathrm{H}_{2}\right)$, superimposed in part $1.78\left(\mathrm{dt}, J=13.6 \mathrm{~Hz}, J^{\prime}=6.8 \mathrm{~Hz}, 1 \mathrm{H}, 3^{\prime \prime}-\mathrm{H}_{\mathrm{A}}\right), 1.80-1.88$ (complex signal, $3 \mathrm{H}, 2-\mathrm{H}_{2}, 3^{\prime \prime}-\mathrm{H}_{\mathrm{B}}$ ), 1.92-2.00 (complex signal, $5 \mathrm{H}$, $\left.2^{\prime}-\mathrm{H}_{2}, 3^{\prime}-\mathrm{H}_{2}, 2^{\prime \prime}-\mathrm{CH}_{\mathrm{A}}-\mathrm{CH}_{2}-\mathrm{NH}\right), 2.07\left(\mathrm{dt}, J=13.6 \mathrm{~Hz}, J^{\prime}=7.2 \mathrm{~Hz}\right.$, $\left.1 \mathrm{H}, 2^{\prime \prime}-\mathrm{CH}_{\mathrm{B}}-\mathrm{CH}_{2}-\mathrm{NH}\right)$, 2.65-2.72 (complex signal, $4 \mathrm{H}, 1^{\prime}-\mathrm{H}_{2}, 4^{\prime \prime}$ $\mathrm{H}_{2}$ ), 2.96-3.04 (complex signal, $\left.4 \mathrm{H}, 8-\mathrm{H}_{2}, 4^{\prime}-\mathrm{H}_{2}\right), 3.21(\mathrm{t}, J=8.0 \mathrm{~Hz}$, $\left.2 \mathrm{H}, 2^{\prime \prime}-\mathrm{CH}_{2}-\mathrm{CH}_{2}-\mathrm{NH}\right), 3.76\left(\mathrm{~s}, 3 \mathrm{H}, 7^{\prime \prime}-\mathrm{OCH}_{3}\right), 3.94(\mathrm{t}, J=6.8 \mathrm{~Hz}$, $\left.2 \mathrm{H}, 1-\mathrm{H}_{2}\right), 4.86\left(\mathrm{~s}, \mathrm{NH},{ }^{+} \mathrm{NH},{ }^{+} \mathrm{NH}_{2}, \mathrm{OH}\right), 6.36\left(\mathrm{~s}, 1 \mathrm{H}, 8^{\prime \prime}-\mathrm{H}\right), 6.49$ $\left(\mathrm{s}, 1 \mathrm{H}, 5^{\prime \prime}-\mathrm{H}\right), 7.56\left(\mathrm{dd}, J=9.2 \mathrm{~Hz}, J^{\prime}=2.4 \mathrm{~Hz}, 1 \mathrm{H}, 7^{\prime}-\mathrm{H}\right), 7.79(\mathrm{~d}, J$ $\left.=2.4 \mathrm{~Hz}, 1 \mathrm{H}, 5^{\prime}-\mathrm{H}\right), 8.39\left(\mathrm{~d}, J=9.2 \mathrm{~Hz}, 1 \mathrm{H}, 8^{\prime}-\mathrm{H}\right) ;{ }^{13} \mathrm{C}$ NMR $(100.6$ $\left.\mathrm{MHz}, \mathrm{CD}_{3} \mathrm{OD}\right) \delta 21.8\left(\mathrm{CH}_{2}, \mathrm{C} 3^{\prime}\right), 22.2\left(\mathrm{CH}_{2}, \mathrm{C} 4^{\prime \prime}\right), 22.9\left(\mathrm{CH}_{2}\right.$ $\left.\mathrm{C}^{\prime}\right), 23.7\left(\mathrm{CH}_{3}, 2^{\prime \prime}-\mathrm{CH}_{3}\right), 24.8\left(\mathrm{CH}_{2}, \mathrm{Cl}^{\prime}\right), 27.2\left(\mathrm{CH}_{2}, \mathrm{C} 7\right), 27.5$ $\left(\mathrm{CH}_{2}\right), 27.6\left(\mathrm{CH}_{2}\right)$ (C3, C6), $29.3\left(\mathrm{CH}_{2}, \mathrm{C}^{\prime}\right), 30.0\left(\mathrm{CH}_{2}\right), 30.1$ $\left(\mathrm{CH}_{2}\right)(\mathrm{C} 4, \mathrm{C} 5), 31.4\left(\mathrm{CH}_{2}, \mathrm{C} 2\right), 32.6\left(\mathrm{CH}_{2}, \mathrm{C} 3^{\prime \prime}\right), 36.4\left(\mathrm{CH}_{2}, 2^{\prime \prime}\right.$. $\left.\mathrm{CH}_{2}-\mathrm{CH}_{2}-\mathrm{NH}\right)$, $44.7\left(\mathrm{CH}_{2}, 2^{\prime \prime}-\mathrm{CH}_{2}-\mathrm{CH}_{2}-\mathrm{NH}\right), 49.2\left(\mathrm{CH}_{2}, \mathrm{C} 8\right), 49.3$ $\left(\mathrm{CH}_{2}, \mathrm{C} 1\right), 56.4\left(\mathrm{CH}_{3}, 7^{\prime \prime}-\mathrm{OCH}_{3}\right), 75.4\left(\mathrm{C}, \mathrm{C} 2^{\prime \prime}\right), 102.2\left(\mathrm{CH}, \mathrm{C}^{\prime \prime}\right)$, 113.3 (2C, C9a', C4a"), $115.4\left(\mathrm{C}, \mathrm{C} 8 \mathrm{a}^{\prime}\right), 116.2\left(\mathrm{CH}, \mathrm{C5}^{\prime \prime}\right), 119.1$ $\left(\mathrm{CH}, \mathrm{C5}^{\prime}\right), 126.8\left(\mathrm{CH}, \mathrm{C7}^{\prime}\right), 128.8\left(\mathrm{CH}, \mathrm{C}^{\prime}\right), 140.1\left(\mathrm{C}, \mathrm{C6}^{\prime}\right), 140.5$ (C, C10a'), 141.3 (C, C6"), 147.2 (C, C8a"), 148.4 (C, C7"), 152.1 (C, C4a'), 157.8 (C, C9'); HRMS (ESI) calcd for $\left(\mathrm{C}_{34} \mathrm{H}_{46}{ }^{35} \mathrm{ClN}_{3} \mathrm{O}_{3}\right.$ $\left.+\mathrm{H}^{+}\right): 580.3300$, found 580.3302; HPLC purity $98 \%$.

$N$-(6-Chloro-1,2,3,4-tetrahydroacridin-9-yl)-N'-[2-(6-hydroxy-7methoxy-2-methylchroman-2-yl)ethyl]nonane-1,9-diamine (6c). It was prepared as described for 6a. From tosylate 15 (142 mg, 0.36 $\mathrm{mmol}$ ) and amine $10 \mathrm{c}(403 \mathrm{mg}, 1.08 \mathrm{mmol})$, a brown oily residue (544 mg) was obtained and subjected to column chromatography purification $\left(35-70 \mu \mathrm{m}\right.$ silica gel, $\mathrm{CH}_{2} \mathrm{Cl}_{2} / \mathrm{MeOH} / 50 \%$ aq $\mathrm{NH}_{4} \mathrm{OH}$ mixtures, gradient elution). On elution with $\mathrm{CH}_{2} \mathrm{Cl}_{2} / \mathrm{MeOH} / 50 \%$ aq $\mathrm{NH}_{4} \mathrm{OH}$ 99.3:0.7:0.4 to 99:1:0.4, amine $6 \mathrm{c}(125 \mathrm{mg}, 59 \%$ yield $)$ was isolated as a beige sticky solid; $R_{f} 0.76\left(\mathrm{CH}_{2} \mathrm{Cl}_{2} / \mathrm{MeOH} / 50 \%\right.$ aq $\mathrm{NH}_{4} \mathrm{OH}$ 90:10:1).

6c.2HCl: beige solid; mp $153-157{ }^{\circ} \mathrm{C}$; IR (ATR) $\nu$ 3600-2200 ( $\max$ at $3229,2925,2852,2785, \mathrm{~N}-\mathrm{H}, \mathrm{N}^{+}-\mathrm{H}, \mathrm{O}-\mathrm{H}, \mathrm{C}-\mathrm{H}$ st), 1628, 1571, 1509 (Ar-C-C, Ar-C-N st) $\mathrm{cm}^{-1}$; ${ }^{1} \mathrm{H}$ NMR $(400 \mathrm{MHz}$, $\left.\mathrm{CD}_{3} \mathrm{OD}\right) \delta 1.30\left(\mathrm{~s}, 3 \mathrm{H}, 2^{\prime \prime}-\mathrm{CH}_{3}\right), 1.32-1.50$ (complex signal, $10 \mathrm{H}, 3-$ $\left.\mathrm{H}_{2}, 4-\mathrm{H}_{2}, 5-\mathrm{H}_{2}, 6-\mathrm{H}_{2}, 7-\mathrm{H}_{2}\right), 1.68\left(\mathrm{~m}, 2 \mathrm{H}, 8-\mathrm{H}_{2}\right)$, superimposed in part $1.79\left(\mathrm{dt}, J=13.2 \mathrm{~Hz}, J^{\prime}=6.4 \mathrm{~Hz}, 1 \mathrm{H}, 3^{\prime \prime}-\mathrm{H}_{\mathrm{A}}\right), 1.80-1.90$ (complex signal, $3 \mathrm{H}, 2-\mathrm{H}_{2}, 3^{\prime \prime}-\mathrm{H}_{\mathrm{B}}$ ), 1.90-2.01 (complex signal, $5 \mathrm{H}$, $\left.2^{\prime}-\mathrm{H}_{2}, 3^{\prime}-\mathrm{H}_{2}, 2^{\prime \prime}-\mathrm{CH}_{\mathrm{A}}-\mathrm{CH}_{2}-\mathrm{NH}\right), 2.06\left(\mathrm{dt}, J=13.6 \mathrm{~Hz}, J^{\prime}=7.6 \mathrm{~Hz}\right.$, $1 \mathrm{H}, 2^{\prime \prime}-\mathrm{CH}_{\mathrm{B}}-\mathrm{CH}_{2}-\mathrm{NH}$ ), 2.64-2.74 (complex signal, 4H, 1'- $-\mathrm{H}_{2}, 4^{\prime \prime}-$ $\left.\mathrm{H}_{2}\right), 2.97-3.03$ (complex signal, $\left.4 \mathrm{H}, 9-\mathrm{H}_{2}, 4^{\prime}-\mathrm{H}_{2}\right), 3.22(\mathrm{t}, J=7.6 \mathrm{~Hz}$, $\left.2 \mathrm{H}, 2^{\prime \prime}-\mathrm{CH}_{2}-\mathrm{CH}_{2}-\mathrm{NH}\right), 3.77\left(\mathrm{~s}, 3 \mathrm{H}, 7^{\prime \prime}-\mathrm{OCH}_{3}\right), 3.94(\mathrm{t}, J=7.6 \mathrm{~Hz}$, $\left.2 \mathrm{H}, 1-\mathrm{H}_{2}\right), 4.85\left(\mathrm{~s}, \mathrm{NH},{ }^{+} \mathrm{NH},{ }^{+} \mathrm{NH}_{2}, \mathrm{OH}\right), 6.36\left(\mathrm{~s}, 1 \mathrm{H}, 8^{\prime \prime}-\mathrm{H}\right), 6.50$ $\left(\mathrm{s}, 1 \mathrm{H}, 5^{\prime \prime}-\mathrm{H}\right), 7.56\left(\mathrm{dd}, J=9.2 \mathrm{~Hz}, J^{\prime}=2.0 \mathrm{~Hz}, 1 \mathrm{H}, 7^{\prime}-\mathrm{H}\right), 7.79(\mathrm{~d}, J$ $\left.=2.0 \mathrm{~Hz}, 1 \mathrm{H}, 5^{\prime}-\mathrm{H}\right), 8.39\left(\mathrm{~d}, J=9.2 \mathrm{~Hz}, 1 \mathrm{H}, 8^{\prime}-\mathrm{H}\right) ;{ }^{13} \mathrm{C}$ NMR $(100.6$ $\left.\mathrm{MHz}, \mathrm{CD}_{3} \mathrm{OD}\right) \delta 21.8\left(\mathrm{CH}_{2}, \mathrm{C}^{\prime}\right), 22.2\left(\mathrm{CH}_{2}, \mathrm{C} 4^{\prime \prime}\right), 22.9\left(\mathrm{CH}_{2}\right.$, $\left.\mathrm{C}^{\prime}\right), 23.7\left(\mathrm{CH}_{3}, 2^{\prime \prime}-\mathrm{CH}_{3}\right), 24.7\left(\mathrm{CH}_{2}, \mathrm{Cl}^{\prime}\right), 27.3\left(\mathrm{CH}_{2}, \mathrm{C} 8\right), 27.5$ $\left(\mathrm{CH}_{2}\right), 27.7\left(\mathrm{CH}_{2}\right)(\mathrm{C} 3, \mathrm{C} 7), 29.3\left(\mathrm{CH}_{2}, \mathrm{C} 4^{\prime}\right), 30.1\left(\mathrm{CH}_{2}\right), 30.2$ $\left(\mathrm{CH}_{2}\right), 30.4\left(\mathrm{CH}_{2}\right)(\mathrm{C} 4, \mathrm{C} 5, \mathrm{C} 6), 31.4\left(\mathrm{CH}_{2}, \mathrm{C} 2\right), 32.6\left(\mathrm{CH}_{2}, \mathrm{C}^{\prime \prime}\right)$, $36.5\left(\mathrm{CH}_{2}, 2\right.$ ' $\left.-\mathrm{CH}_{2}-\mathrm{CH}_{2}-\mathrm{NH}\right), 44.7\left(\mathrm{CH}_{2}, 2^{\prime \prime}-\mathrm{CH}_{2}-\mathrm{CH}_{2}-\mathrm{NH}\right), 48.9$ $\left(\mathrm{CH}_{2}\right), 49.1\left(\mathrm{CH}_{2}\right)(\mathrm{C} 1, \mathrm{C} 9), 56.4\left(\mathrm{CH}_{3}, 7^{\prime \prime}-\mathrm{OCH}_{3}\right), 75.4\left(\mathrm{C}, \mathrm{C} 2^{\prime \prime}\right)$, $102.2\left(\mathrm{CH}, \mathrm{C} 8^{\prime \prime}\right), 113.4\left(2 \mathrm{C}, \mathrm{C}^{\prime} \mathrm{a}^{\prime}, \mathrm{C} 4 \mathrm{a}^{\prime \prime}\right), 115.5\left(\mathrm{C}, \mathrm{C} 8 \mathrm{a}^{\prime}\right), 116.2$ $\left(\mathrm{CH}, \mathrm{C5}^{\prime \prime}\right), 119.2\left(\mathrm{CH}, \mathrm{C5}^{\prime}\right), 126.8\left(\mathrm{CH}, \mathrm{C}^{\prime}\right), 128.8\left(\mathrm{CH}, \mathrm{C}^{\prime}\right)$,

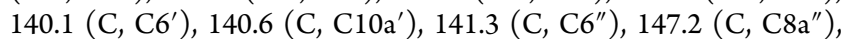

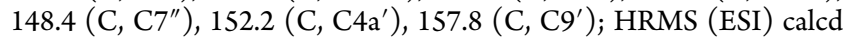
for $\left(\mathrm{C}_{35} \mathrm{H}_{48}{ }^{35} \mathrm{ClN}_{3} \mathrm{O}_{3}+\mathrm{H}^{+}\right)$: 594.3457, found 594.3461; HPLC purity 97\%.

$\mathrm{N}$-(6-Chloro-1,2,3,4-tetrahydroacridin-9-yl)-N'-[2-(6-hydroxy-7methoxy-2-methylchroman-2-yl)ethyl]-3,6-dioxaoctane-1,8-diamine (6d). It was prepared as described for 6a. From tosylate 15 (200 $\mathrm{mg}, 0.51 \mathrm{mmol})$ and amine $10 \mathrm{~d}(553 \mathrm{mg}, 1.52 \mathrm{mmol})$, a brown sticky solid $(763 \mathrm{mg})$ was obtained and subjected to column chromatography purification $\left(35-70 \mu \mathrm{m}\right.$ silica gel, $\mathrm{CH}_{2} \mathrm{Cl}_{2} / \mathrm{MeOH} / 50 \%$ aq $\mathrm{NH}_{4} \mathrm{OH}$ mixtures, gradient elution). On elution with $\mathrm{CH}_{2} \mathrm{Cl}_{2}$ / $\mathrm{MeOH} / 50 \%$ aq $\mathrm{NH}_{4} \mathrm{OH}$ 99.3:0.7:0.4 to 99:1:0.4, amine 6d (90 mg, $30 \%$ yield) was isolated as a brown solid; $R_{f} 0.77\left(\mathrm{CH}_{2} \mathrm{Cl}_{2} / \mathrm{MeOH} /\right.$ $50 \%$ aq $\mathrm{NH}_{4} \mathrm{OH}$ 90:10:1).

6d.2HCl: brown sticky solid; IR (ATR) $\nu$ 3600-2200 (max at $3369,3250,2919,2857,2790, \mathrm{~N}-\mathrm{H}, \mathrm{N}^{+}-\mathrm{H}, \mathrm{O}-\mathrm{H}, \mathrm{C}-\mathrm{H}$ st), 1630,
1576, 1509 (Ar-C-C, Ar-C-N st) cm ${ }^{-1}$; ${ }^{1} \mathrm{H}$ NMR $(400 \mathrm{MHz}$, $\left.\mathrm{CD}_{3} \mathrm{OD}\right) \delta 1.27\left(\mathrm{~s}, 3 \mathrm{H}, 2^{\prime \prime}-\mathrm{CH}_{3}\right), 1.74\left(\mathrm{dt}, J=14.0 \mathrm{~Hz}, J^{\prime}=6.4 \mathrm{~Hz}\right.$, $\left.1 \mathrm{H}, 3^{\prime \prime}-\mathrm{H}_{\mathrm{A}}\right), 1.79\left(\mathrm{dt}, J=14.0 \mathrm{~Hz}, J^{\prime}=6.4 \mathrm{~Hz}, 1 \mathrm{H}, 3^{\prime \prime}-\mathrm{H}_{\mathrm{B}}\right), 1.92-2.00$ (complex signal, $\left.5 \mathrm{H}, 2^{\prime}-\mathrm{H}_{2}, 3^{\prime}-\mathrm{H}_{2}, 2^{\prime \prime}-\mathrm{CH}_{\mathrm{A}}-\mathrm{CH}_{2}-\mathrm{NH}\right), 2.05(\mathrm{dt}, J=$ $\left.14.0 \mathrm{~Hz}, J^{\prime}=6.8 \mathrm{~Hz}, 1 \mathrm{H}, 2^{\prime \prime}-\mathrm{CH}_{\mathrm{B}}-\mathrm{CH}_{2}-\mathrm{NH}\right), 2.56\left(\mathrm{dt}, J=12.0 \mathrm{~Hz}, J^{\prime}\right.$ $\left.=6.4 \mathrm{~Hz}, 1 \mathrm{H}, 4^{\prime \prime}-\mathrm{H}_{\mathrm{A}}\right), 2.60-2.70$ (complex signal, $\left.3 \mathrm{H}, 1^{\prime}-\mathrm{H}_{2}, 4^{\prime \prime}-\mathrm{H}_{\mathrm{B}}\right)$, $3.01\left(\mathrm{br} \mathrm{t}, J=5.6 \mathrm{~Hz}, 2 \mathrm{H}, 4^{\prime}-\mathrm{H}_{2}\right), 3.25\left(\mathrm{t}, J=4.8 \mathrm{~Hz}, 2 \mathrm{H}, 8-\mathrm{H}_{2}\right)$, superimposed in part $3.31\left(\mathrm{~m}, 2 \mathrm{H}, 2^{\prime \prime}-\mathrm{CH}_{2}-\mathrm{CH}_{2}-\mathrm{NH}\right), 3.66-3.73$ (complex signal, 4H, 4- $\left.\mathrm{H}_{2}, 7-\mathrm{H}_{2}\right), 3.71\left(\mathrm{~s}, 3 \mathrm{H}, 7^{\prime \prime}-\mathrm{OCH}_{3}\right), 3.77(\mathrm{t}, \mathrm{J}=$ $\left.4.8 \mathrm{~Hz}, 2 \mathrm{H}, 5-\mathrm{H}_{2}\right), 3.88\left(\mathrm{~m}, 2 \mathrm{H}, 2-\mathrm{H}_{2}\right), 4.11\left(\mathrm{t}, J=4.8 \mathrm{~Hz}, 2 \mathrm{H}, 1-\mathrm{H}_{2}\right)$, $4.85\left(\mathrm{~s}, \mathrm{NH},{ }^{+} \mathrm{NH},{ }^{+} \mathrm{NH}_{2}, \mathrm{OH}\right), 6.31\left(\mathrm{~s}, 1 \mathrm{H}, 8^{\prime \prime}-\mathrm{H}\right), 6.40\left(\mathrm{~s}, 1 \mathrm{H}, 5^{\prime \prime}-\right.$ $\mathrm{H}), 7.54\left(\mathrm{dd}, J=9.2 \mathrm{~Hz}, J^{\prime}=2.0 \mathrm{~Hz}, 1 \mathrm{H}, 7^{\prime}-\mathrm{H}\right), 7.78(\mathrm{~d}, J=2.0 \mathrm{~Hz}$, $\left.1 \mathrm{H}, 5^{\prime}-\mathrm{H}\right), 8.43\left(\mathrm{~d}, J=9.2 \mathrm{~Hz}, 1 \mathrm{H}, 8^{\prime}-\mathrm{H}\right) ;{ }^{13} \mathrm{C}$ NMR $(100.6 \mathrm{MHz}$, $\left.\mathrm{CD}_{3} \mathrm{OD}\right) \delta 21.7\left(\mathrm{CH}_{2}, \mathrm{C}^{\prime}\right), 22.1\left(\mathrm{CH}_{2}, \mathrm{C}^{\prime \prime}\right), 22.8\left(\mathrm{CH}_{2}, \mathrm{C}^{\prime}\right), 23.4$ $\left(\mathrm{CH}_{3}, 2^{\prime \prime}-\mathrm{CH}_{3}\right), 24.6\left(\mathrm{CH}_{2}, \mathrm{Cl}^{\prime}\right), 29.3\left(\mathrm{CH}_{2}, \mathrm{C}^{\prime}\right), 32.6\left(\mathrm{CH}_{2}, \mathrm{C}^{\prime \prime}\right)$, $36.4\left(\mathrm{CH}_{2}, 2^{\prime \prime}-\mathrm{CH}_{2}-\mathrm{CH}_{2}-\mathrm{NH}\right), 44.8\left(\mathrm{CH}_{2}, 2^{\prime \prime}-\mathrm{CH}_{2}-\mathrm{CH}_{2}-\mathrm{NH}\right), 48.5$ $\left(\mathrm{CH}_{2}, \mathrm{C} 8\right), 49.1\left(\mathrm{CH}_{2}, \mathrm{C} 1\right), 56.5\left(\mathrm{CH}_{3}, 7^{\prime \prime}-\mathrm{OCH}_{3}\right), 66.8\left(\mathrm{CH}_{2}, \mathrm{C} 4\right)$, $70.4\left(\mathrm{CH}_{2}, \mathrm{C} 2\right), 71.3\left(\mathrm{CH}_{2}\right), 71.4\left(\mathrm{CH}_{2}\right)(\mathrm{C} 5, \mathrm{C} 7), 75.9\left(\mathrm{C}, \mathrm{C} 2^{\prime \prime}\right)$, $102.3\left(\mathrm{CH}, \mathrm{C} 8^{\prime \prime}\right), 113.4\left(\mathrm{C}, \mathrm{C} 9 \mathrm{a}^{\prime}\right), 113.7\left(\mathrm{C}, \mathrm{C}^{\prime \prime} \mathrm{a}^{\prime \prime}\right), 115.6\left(\mathrm{C}, \mathrm{C} 8 \mathrm{a}^{\prime}\right)$, $116.1\left(\mathrm{CH}, \mathrm{C5}^{\prime \prime}\right), 119.2\left(\mathrm{CH}, \mathrm{C5}^{\prime}\right), 126.8\left(\mathrm{CH}, \mathrm{C}^{\prime}\right), 128.8(\mathrm{CH}$, C8') 140.1 (C, C6'), $140.4\left(\mathrm{C}, \mathrm{C} 10 \mathrm{a}^{\prime}\right), 141.4\left(\mathrm{C}, \mathrm{C} 6^{\prime \prime}\right), 146.8$ (C, C8a"), 148.3 (C, C7"), 152.4 (C, C4a'), 158.2 (C, C9'); HRMS (ESI) calcd for $\left(\mathrm{C}_{32} \mathrm{H}_{42}{ }^{35} \mathrm{ClN}_{3} \mathrm{O}_{5}+\mathrm{H}^{+}\right)$: 584.2886, found 584.2879; HPLC purity $98 \%$.

$N$-\{7-[(6-Chloro-1,2,3,4-tetrahydroacridin-9-yl)amino]heptyl\}-2(6-benzyloxy-7-methoxy-2-methylchroman-2-yl)acetamide (11a). It was prepared as described for 4a. From carboxylic acid 8 (200 $\mathrm{mg}, 0.58 \mathrm{mmol})$ and amine $10 \mathrm{a}(222 \mathrm{mg}, 0.64 \mathrm{mmol})$, a brown solid (784 mg) was obtained and subjected to column chromatography purification (35-70 $\mu \mathrm{m}$ silica gel, $\mathrm{CH}_{2} \mathrm{Cl}_{2} / \mathrm{MeOH} / 50 \%$ aq $\mathrm{NH}_{4} \mathrm{OH}$ mixtures, gradient elution). On elution with $\mathrm{CH}_{2} \mathrm{Cl}_{2} / \mathrm{MeOH} / 50 \%$ aq $\mathrm{NH}_{4} \mathrm{OH}$ 100:0:0.4 to 95:5:0.4, amide 11a (326 mg, 83\% yield) was isolated as a light yellow solid; $R_{f} 0.73\left(\mathrm{CH}_{2} \mathrm{Cl}_{2} / \mathrm{MeOH} / 50 \%\right.$ aq $\mathrm{NH}_{4} \mathrm{OH}$ 90:10:1)

11a. $\mathrm{HCl}$ : light yellow solid; mp 107-109 ${ }^{\circ} \mathrm{C}$; IR (ATR) $\nu$ 36002200 ( $\max$ at $3255,3053,2929,2852, \mathrm{~N}-\mathrm{H}, \mathrm{N}^{+}-\mathrm{H}, \mathrm{C}-\mathrm{H}$ st), 1632, 1568, $1512(\mathrm{C}=\mathrm{O}, \mathrm{Ar}-\mathrm{C}-\mathrm{C}, \mathrm{Ar}-\mathrm{C}-\mathrm{N}$ st $) \mathrm{cm}^{-1} ;{ }^{1} \mathrm{H}$ NMR $(400$ $\mathrm{MHz}, \mathrm{CD}_{3} \mathrm{OD}$ ) $\delta 1.27-1.38$ (complex signal, $6 \mathrm{H}, 3^{\prime}-\mathrm{H}_{2}, 4^{\prime}-\mathrm{H}_{2}, 5^{\prime}-$ $\left.\mathrm{H}_{2}\right), 1.33\left(\mathrm{~s}, 3 \mathrm{H}, 2-\mathrm{CH}_{3}\right), 1.48\left(\mathrm{tt}, J=J^{\prime}=6.8 \mathrm{~Hz}, 2 \mathrm{H}, 2^{\prime}-\mathrm{H}_{2}\right)$, superimposed in part $1.75\left(\mathrm{tt}, J=J^{\prime}=6.4 \mathrm{~Hz}, 2 \mathrm{H}, 6^{\prime}-\mathrm{H}_{2}\right), 1.80(\mathrm{dt}, J=$ $\left.13.6 \mathrm{~Hz}, J^{\prime}=5.6 \mathrm{~Hz}, 1 \mathrm{H}, 3-\mathrm{H}_{\mathrm{A}}\right)$, superimposed in part $1.90(\mathrm{dt}, J=$ $13.6 \mathrm{~Hz}, J^{\prime}=5.6 \mathrm{~Hz}, 1 \mathrm{H}, 3-\mathrm{H}_{\mathrm{B}}$ ), $1.88-1.98$ (complex signal, $4 \mathrm{H}, 2^{\prime \prime}$ $\mathrm{H}_{2}, 3^{\prime \prime}-\mathrm{H}_{2}$ ), 2.45 (d, $\left.J=13.6 \mathrm{~Hz}, 1 \mathrm{H}, 2-\mathrm{CH}_{\mathrm{A}}-\mathrm{CO}\right), 2.53$ (d, $J=13.6$ $\left.\mathrm{Hz}, 1 \mathrm{H}, 2-\mathrm{CH}_{\mathrm{B}}-\mathrm{CO}\right), 2.61\left(\mathrm{t}, J=6.0 \mathrm{~Hz}, 2 \mathrm{H}, 1^{\prime \prime}-\mathrm{H}_{2}\right), 2.67(\mathrm{~m}, 2 \mathrm{H}, 4-$ $\left.\mathrm{H}_{2}\right), 2.94\left(\mathrm{t}, J=5.6 \mathrm{~Hz}, 2 \mathrm{H}, 4^{\prime \prime}-\mathrm{H}_{2}\right), 3.14\left(\mathrm{dt}, J=13.6 \mathrm{~Hz}, J^{\prime}=6.4 \mathrm{~Hz}\right.$, $\left.1 \mathrm{H}, 1^{\prime}-\mathrm{H}_{\mathrm{A}}\right), 3.25\left(\mathrm{dt}, J=13.6 \mathrm{~Hz}, J^{\prime}=6.4 \mathrm{~Hz}, 1 \mathrm{H}, 1^{\prime}-\mathrm{H}_{\mathrm{B}}\right), 3.76(\mathrm{~s}$, $\left.3 \mathrm{H}, 7-\mathrm{OCH}_{3}\right), 3.86\left(\mathrm{t}, J=7.6 \mathrm{~Hz}, 2 \mathrm{H}, 7^{\prime}-\mathrm{H}_{2}\right), 4.85\left(\mathrm{~s}, \mathrm{NH},{ }^{+} \mathrm{NH}\right)$, $4.89\left(\mathrm{~d}, J=11.6 \mathrm{~Hz}, 1 \mathrm{H}, 6-\mathrm{OCH}_{\mathrm{A}}\right), 4.93(\mathrm{~d}, J=11.6 \mathrm{~Hz}, 1 \mathrm{H}, 6-$ $\left.\mathrm{OCH}_{\mathrm{B}}\right), 6.41(\mathrm{~s}, 1 \mathrm{H}, 8-\mathrm{H}), 6.67(\mathrm{~s}, 1 \mathrm{H}, 5-\mathrm{H}), 7.22-7.32$ [complex signal, $3 \mathrm{H}$, benzyl 3(5)- $\mathrm{H}$, benzyl 4-H], $7.35\left[\mathrm{dd}, J=8.4 \mathrm{~Hz}, J^{\prime}=1.6\right.$ $\mathrm{Hz}, 2 \mathrm{H}$, benzyl $2(6)-\mathrm{H}], 7.53\left(\mathrm{dd}, J=9.2 \mathrm{~Hz}, J^{\prime}=2.0 \mathrm{~Hz}, 1 \mathrm{H}, 7^{\prime \prime}-\mathrm{H}\right)$, $7.71\left(\mathrm{~d}, J=2.0 \mathrm{~Hz}, 1 \mathrm{H}, 5^{\prime \prime}-\mathrm{H}\right), 8.33\left(\mathrm{~d}, J=9.2 \mathrm{~Hz}, 1 \mathrm{H}, 8^{\prime \prime}-\mathrm{H}\right) ;{ }^{13} \mathrm{C}$ NMR (100.6 MHz, CD 3 OD) $\delta 21.7\left(\mathrm{CH}_{2}, \mathrm{C}^{\prime \prime}\right), 22.4\left(\mathrm{CH}_{2}, \mathrm{C} 4\right)$, $22.8\left(\mathrm{CH}_{2}, \mathrm{C} 2^{\prime \prime}\right), 24.63\left(\mathrm{CH}_{2}, \mathrm{C} 1^{\prime \prime}\right), 24.64\left(\mathrm{CH}_{3}, 2-\mathrm{CH}_{3}\right), 27.7$ $\left(\mathrm{CH}_{2}\right), 27.8\left(\mathrm{CH}_{2}\right)\left(\mathrm{C}^{\prime}, \mathrm{C}^{\prime}\right), 29.3\left(\mathrm{CH}_{2}, \mathrm{C}^{\prime \prime}\right), 30.0\left(\mathrm{CH}_{2}, \mathrm{C}^{\prime}\right)$, $30.3\left(\mathrm{CH}_{2}, \mathrm{C} 2^{\prime}\right), 31.3\left(\mathrm{CH}_{2}, \mathrm{C}^{\prime}\right), 32.0\left(\mathrm{CH}_{2}, \mathrm{C} 3\right), 40.1\left(\mathrm{CH}_{2}, \mathrm{Cl}^{\prime}\right)$, $47.7\left(\mathrm{CH}_{2}, 2-\mathrm{CH}_{2}-\mathrm{CO}\right), 49.3\left(\mathrm{CH}_{2}, \mathrm{C}^{\prime}\right), 56.5\left(\mathrm{CH}_{3}, 7-\mathrm{OCH}_{3}\right), 73.5$ $\left(\mathrm{CH}_{2}, 6-\mathrm{OCH}_{2}\right), 75.9(\mathrm{C}, \mathrm{C} 2), 103.1(\mathrm{CH}, \mathrm{C} 8), 113.2\left(2 \mathrm{C}, \mathrm{C}^{\prime \prime}\right.$, C4a), 115.4 (C, C8a"), $117.7(\mathrm{CH}, \mathrm{C} 5), 119.1\left(\mathrm{CH}, \mathrm{C5}^{\prime \prime}\right), 126.7$ $\left(\mathrm{CH}, \mathrm{C}^{\prime \prime}\right), 128.7$ [3CH, benzyl $\mathrm{C} 2(6)$, benzyl $\left.\mathrm{C} 4\right], 128.8(\mathrm{CH}$, C8"), 129.3 [2CH, benzyl C3(5)], 138.9 (C, benzyl C1), 140.1 (C, $\mathrm{C}^{\prime \prime}$ ), 140.5 (C, C10a"), 143.3 (C, C6), 149.3 (C, C8a), 151.0 (C, C7), 151.9 (C, C4a"), 157.6 (C, C9"), 172.3 (C, CONH); HRMS (ESI) calcd for $\left(\mathrm{C}_{40} \mathrm{H}_{48}{ }^{35} \mathrm{ClN}_{3} \mathrm{O}_{4}+\mathrm{H}^{+}\right): 670.3406$, found 670.3400; HPLC purity $97 \%$.

$N$-\{8-[(6-Chloro-1,2,3,4-tetrahydroacridin-9-yl)amino]octy/\}-2(6-benzyloxy-7-methoxy-2-methylchroman-2-yl)acetamide (11b). It was prepared as described for 4a. From carboxylic acid 8 (100 $\mathrm{mg}, 0.29 \mathrm{mmol}$ ) and amine $10 \mathrm{~b}(116 \mathrm{mg}, 0.32 \mathrm{mmol})$, a brown solid (462 mg) was obtained and subjected to column chromatography 
purification $\left(35-70 \mu \mathrm{m}\right.$ silica gel, $\mathrm{CH}_{2} \mathrm{Cl}_{2} / \mathrm{MeOH} / 50 \%$ aq $\mathrm{NH}_{4} \mathrm{OH}$ mixtures, gradient elution). On elution with $\mathrm{CH}_{2} \mathrm{Cl}_{2} / \mathrm{MeOH} / 50 \%$ aq $\mathrm{NH}_{4} \mathrm{OH}$ 100:0:0.4, amide $11 \mathrm{~b}$ (183 mg, 92\% yield) was isolated as a yellow solid; $R_{f} 0.73\left(\mathrm{CH}_{2} \mathrm{Cl}_{2} / \mathrm{MeOH} / 50 \%\right.$ aq $\mathrm{NH}_{4} \mathrm{OH}$ 90:10:1).

11b. HCl: light yellow solid; mp $127-129^{\circ} \mathrm{C}$; IR (ATR) $\nu 3600$ 2200 ( $\max$ at $3261,3053,2924,2852, \mathrm{~N}-\mathrm{H}, \mathrm{N}^{+}-\mathrm{H}, \mathrm{C}-\mathrm{H}$ st), 1632, $1571,1510(\mathrm{C}=\mathrm{O}, \mathrm{Ar}-\mathrm{C}-\mathrm{C}, \mathrm{Ar}-\mathrm{C}-\mathrm{N}$ st $) \mathrm{cm}^{-1} ;{ }^{1} \mathrm{H}$ NMR $(400$ $\left.\mathrm{MHz}, \mathrm{CD}_{3} \mathrm{OD}\right) \delta 1.20-1.34$ (complex signal, $6 \mathrm{H}, 3^{\prime}-\mathrm{H}_{2}, 4^{\prime}-\mathrm{H}_{2}, 5^{\prime}-$ $\left.\mathrm{H}_{2}\right), 1.33\left(\mathrm{~s}, 3 \mathrm{H}, 2-\mathrm{CH}_{3}\right), 1.37\left(\mathrm{tt}, J=J^{\prime}=6.8 \mathrm{~Hz}, 2 \mathrm{H}, 6^{\prime}-\mathrm{H}_{2}\right), 1.48$ $\left(\mathrm{tt}, J=J^{\prime}=6.8 \mathrm{~Hz}, 2 \mathrm{H}, 2^{\prime}-\mathrm{H}_{2}\right)$, superimposed in part $1.77(\mathrm{tt}, J=7.2$ $\left.\mathrm{Hz}, J^{\prime}=6.8 \mathrm{~Hz}, 2 \mathrm{H}, 7^{\prime}-\mathrm{H}_{2}\right), 1.79\left(\mathrm{dt}, J=13.6 \mathrm{~Hz}, J^{\prime}=6.8 \mathrm{~Hz}, 1 \mathrm{H}, 3-\right.$ $\left.\mathrm{H}_{\mathrm{A}}\right)$, superimposed in part $1.90\left(\mathrm{dt}, J=13.6 \mathrm{~Hz}, J^{\prime}=6.8 \mathrm{~Hz}, 1 \mathrm{H}, 3-\right.$ $\mathrm{H}_{\mathrm{B}}$ ), 1.87-1.99 (complex signal, $\left.4 \mathrm{H}, 2^{\prime \prime}-\mathrm{H}_{2}, 3^{\prime \prime}-\mathrm{H}_{2}\right), 2.45(\mathrm{~d}, J=13.6$ $\left.\mathrm{Hz}, 1 \mathrm{H}, 2-\mathrm{CH}_{\mathrm{A}}-\mathrm{CO}\right), 2.53\left(\mathrm{~d}, J=13.6 \mathrm{~Hz}, 1 \mathrm{H}, 2-\mathrm{CH}_{\mathrm{B}}-\mathrm{CO}\right), 2.61(\mathrm{t}, J$ $\left.=5.6 \mathrm{~Hz}, 2 \mathrm{H}, 1^{\prime \prime}-\mathrm{H}_{2}\right), 2.67\left(\mathrm{~m}, 2 \mathrm{H}, 4-\mathrm{H}_{2}\right), 2.94\left(\mathrm{t}, J=6.0 \mathrm{~Hz}, 2 \mathrm{H}, 4^{\prime \prime}-\right.$ $\left.\mathrm{H}_{2}\right), 3.14\left(\mathrm{dt}, J=13.6 \mathrm{~Hz}, J^{\prime}=6.8 \mathrm{~Hz}, 1 \mathrm{H}, 1^{\prime}-\mathrm{H}_{\mathrm{A}}\right), 3.25(\mathrm{dt}, J=13.6$ $\left.\mathrm{Hz}, J^{\prime}=6.8 \mathrm{~Hz}, 1 \mathrm{H}, \mathrm{1}^{\prime}-\mathrm{H}_{\mathrm{B}}\right), 3.77\left(\mathrm{~s}, 3 \mathrm{H}, 7-\mathrm{OCH}_{3}\right), 3.85(\mathrm{t}, J=7.2$ $\left.\mathrm{Hz}, 2 \mathrm{H}, 8^{\prime}-\mathrm{H}_{2}\right), 4.85\left(\mathrm{~s}, \mathrm{NH},{ }^{+} \mathrm{NH}\right), 4.89(\mathrm{~d}, J=12.0 \mathrm{~Hz}, 1 \mathrm{H}, 6-$ $\left.\mathrm{OCH}_{\mathrm{A}}\right), 4.93\left(\mathrm{~d}, J=12.0 \mathrm{~Hz}, 1 \mathrm{H}, 6-\mathrm{OCH}_{\mathrm{B}}\right), 6.42(\mathrm{~s}, 1 \mathrm{H}, 8-\mathrm{H}), 6.67$ (s, 1H, 5-H), 7.18-7.30 [complex signal, $3 \mathrm{H}$, benzyl 3(5)-H, benzyl $4-\mathrm{H}], 7.35[\mathrm{dm}, J=8.0 \mathrm{~Hz}, 2 \mathrm{H}$, benzyl $2(6)-\mathrm{H}], 7.52(\mathrm{dd}, J=9.2 \mathrm{~Hz}$, $\left.J^{\prime}=2.0 \mathrm{~Hz}, 1 \mathrm{H}, 7^{\prime \prime}-\mathrm{H}\right), 7.72\left(\mathrm{~d}, J=2.0 \mathrm{~Hz}, 1 \mathrm{H}, 5^{\prime \prime}-\mathrm{H}\right), 8.33(\mathrm{~d}, J=9.2$ $\left.\mathrm{Hz}, 1 \mathrm{H}, 8^{\prime \prime}-\mathrm{H}\right) ;{ }^{13} \mathrm{C}$ NMR (100.6 MHz, $\left.\mathrm{CD}_{3} \mathrm{OD}\right) \delta 21.7\left(\mathrm{CH}_{2}, \mathrm{C}^{\prime \prime}\right)$, $22.4\left(\mathrm{CH}_{2}, \mathrm{C} 4\right), 22.8\left(\mathrm{CH}_{2}, \mathrm{Cl}^{\prime \prime}\right), 24.62\left(\mathrm{CH}_{2}, \mathrm{Cl}^{\prime \prime}\right), 24.63\left(\mathrm{CH}_{3}, 2-\right.$ $\left.\mathrm{CH}_{3}\right)$, $27.6\left(\mathrm{CH}_{2}, \mathrm{C6}^{\prime}\right), 27.8\left(\mathrm{CH}_{2}, \mathrm{C5}^{\prime}\right), 29.3\left(\mathrm{CH}_{2}, \mathrm{C} 4^{\prime \prime}\right), 30.2$ $\left(\mathrm{CH}_{2}\right), 30.3\left(\mathrm{CH}_{2}\right)\left(\mathrm{C}^{\prime}, \mathrm{C}^{\prime}\right), 30.4\left(\mathrm{CH}_{2}, \mathrm{C}^{\prime}\right), 31.4\left(\mathrm{CH}_{2}, \mathrm{C}^{\prime}\right)$, $32.0\left(\mathrm{CH}_{2}, \mathrm{C} 3\right), 40.2\left(\mathrm{CH}_{2}, \mathrm{Cl}^{\prime}\right), 47.7\left(\mathrm{CH}_{2}, 2-\mathrm{CH}_{2}-\mathrm{CO}\right), 49.3$ $\left(\mathrm{CH}_{2}, \mathrm{C}^{\prime}\right), 56.5\left(\mathrm{CH}_{3}, 7-\mathrm{OCH}_{3}\right), 73.4\left(\mathrm{CH}_{2}, 6-\mathrm{OCH}_{2}\right), 75.9(\mathrm{C}$, C2), 103.0 (CH, C8), 113.17 (C), 113.20 (C) (C4a, C9a"), 115.3 (C, C8a"), $117.5(\mathrm{CH}, \mathrm{C5}), 119.1\left(\mathrm{CH}, \mathrm{C5}^{\prime \prime}\right), 126.7\left(\mathrm{CH}, \mathrm{C}^{\prime \prime}\right)$, 128.7 [3CH, benzyl C2(6), benzyl C4], $128.8(\mathrm{CH}, \mathrm{C} 8 "), 129.3$ [2CH, benzyl C3(5)], 138.9 (C, benzyl C1), 140.0 (C, C6"), 140.5 (C, C10a"), 143.3 (C, C6), 149.3 (C, C8a), 150.9 (C, C7), 151.9 (C, C4a"), 157.6 (C, C9"), $172.3(\mathrm{C}, \mathrm{CONH})$; HRMS (ESI) calcd for $\left(\mathrm{C}_{41} \mathrm{H}_{50}{ }^{35} \mathrm{ClN}_{3} \mathrm{O}_{4}+\mathrm{H}^{+}\right): 684.3562$, found 684.3563; HPLC purity $99 \%$.

$N$-\{9-[(6-Chloro-1,2,3,4-tetrahydroacridin-9-yl)amino]nonyl\}-2(6-benzyloxy-7-methoxy-2-methylchroman-2-yl)acetamide (11c). It was prepared as described for 4a. From carboxylic acid 8 (128 $\mathrm{mg}, 0.37 \mathrm{mmol})$ and amine $10 \mathrm{c}(154 \mathrm{mg}, 0.41 \mathrm{mmol})$, a brown oily residue $(521 \mathrm{mg})$ was obtained and subjected to column chromatography purification $\left(35-70 \mu \mathrm{m}\right.$ silica gel, $\mathrm{CH}_{2} \mathrm{Cl}_{2} /$ $\mathrm{MeOH} / 50 \%$ aq $\mathrm{NH}_{4} \mathrm{OH}$ mixtures, gradient elution). On elution with $\mathrm{CH}_{2} \mathrm{Cl}_{2} / \mathrm{MeOH} / 50 \%$ aq $\mathrm{NH}_{4} \mathrm{OH}$ 100:0:0.4-99:1:0.4, amide $11 \mathrm{c}\left(236 \mathrm{mg}, 90 \%\right.$ yield) was isolated as a light yellow solid; $R_{f} 0.74$ $\left(\mathrm{CH}_{2} \mathrm{Cl}_{2} / \mathrm{MeOH} / 50 \%\right.$ aq $\mathrm{NH}_{4} \mathrm{OH}$ 90:10:1).

11c. HCl: light yellow solid; mp $107-109^{\circ} \mathrm{C}$; IR (ATR) $\nu 3600-$ 2200 ( $\max$ at $3244,3053,2924,2852, \mathrm{~N}-\mathrm{H}, \mathrm{N}^{+}-\mathrm{H}, \mathrm{C}-\mathrm{H}$ st), 1633 , 1573, 1510 (C=O, Ar-C-C, Ar-C-N st) $\mathrm{cm}^{-1} ;{ }^{1} \mathrm{H}$ NMR (400 $\mathrm{MHz}, \mathrm{CD}_{3} \mathrm{OD}$ ) $\delta 1.18-1.36$ (complex signal, $8 \mathrm{H}, 3^{\prime}-\mathrm{H}_{2}, 4^{\prime}-\mathrm{H}_{2}, 5^{\prime}-\mathrm{H}_{2}$, $\left.6^{\prime}-\mathrm{H}_{2}\right), 1.33\left(\mathrm{~s}, 3 \mathrm{H}, 2-\mathrm{CH}_{3}\right), 1.39\left(\mathrm{tt}, J=7.6 \mathrm{~Hz}, J^{\prime}=6.8 \mathrm{~Hz}, 2 \mathrm{H}, 7^{\prime}-\right.$ $\left.\mathrm{H}_{2}\right), 1.48\left(\mathrm{tt}, J=J^{\prime}=6.8 \mathrm{~Hz}, 2 \mathrm{H}, 2^{\prime}-\mathrm{H}_{2}\right)$, superimposed in part 1.77 $\left(\mathrm{tt}, J=7.6 \mathrm{~Hz}, J^{\prime}=7.2 \mathrm{~Hz}, 2 \mathrm{H}, 8^{\prime}-\mathrm{H}_{2}\right), 1.80\left(\mathrm{dt}, J=13.2 \mathrm{~Hz}, J^{\prime}=6.0\right.$ $\left.\mathrm{Hz}, 1 \mathrm{H}, 3-\mathrm{H}_{\mathrm{A}}\right)$, superimposed in part $1.90\left(\mathrm{dt}, J=13.2 \mathrm{~Hz}, J^{\prime}=6.0\right.$ $\mathrm{Hz}, 1 \mathrm{H}, 3-\mathrm{H}_{\mathrm{B}}$ ), 1.87-1.98 (complex signal, $4 \mathrm{H}, 2^{\prime \prime}-\mathrm{H}_{2}, 3$ 3"- $\mathrm{H}_{2}$ ), 2.45 $\left(\mathrm{d}, J=13.6 \mathrm{~Hz}, 1 \mathrm{H}, 2-\mathrm{CH}_{\mathrm{A}}-\mathrm{CO}\right), 2.52\left(\mathrm{~d}, J=13.6 \mathrm{~Hz}, 1 \mathrm{H}, 2-\mathrm{CH}_{\mathrm{B}^{-}}\right.$ CO), $2.63\left(\mathrm{t}, J=5.2 \mathrm{~Hz}, 2 \mathrm{H}, 1^{\prime \prime}-\mathrm{H}_{2}\right), 2.69\left(\mathrm{~m}, 2 \mathrm{H}, 4-\mathrm{H}_{2}\right), 2.95(\mathrm{t}, J=$ $\left.6.0 \mathrm{~Hz}, 2 \mathrm{H}, 4^{\prime \prime}-\mathrm{H}_{2}\right), 3.14\left(\mathrm{dt}, J=13.2 \mathrm{~Hz}, J^{\prime}=6.8 \mathrm{~Hz}, 1 \mathrm{H}, 1^{\prime}-\mathrm{H}_{\mathrm{A}}\right)$, $3.23\left(\mathrm{dt}, J=13.2 \mathrm{~Hz}, J^{\prime}=6.8 \mathrm{~Hz}, 1 \mathrm{H}, 1^{\prime}-\mathrm{H}_{\mathrm{B}}\right), 3.77\left(\mathrm{~s}, 3 \mathrm{H}, 7-\mathrm{OCH}_{3}\right)$, $3.87\left(\mathrm{t}, J=7.2 \mathrm{~Hz}, 2 \mathrm{H}, 9^{\prime}-\mathrm{H}_{2}\right), 4.85\left(\mathrm{~s}, \mathrm{NH},{ }^{+} \mathrm{NH}\right), 4.91(\mathrm{~d}, J=12.4$ $\left.\mathrm{Hz}, 1 \mathrm{H}, 6-\mathrm{OCH}_{\mathrm{A}}\right), 4.94\left(\mathrm{~d}, J=12.4 \mathrm{~Hz}, 1 \mathrm{H}, 6-\mathrm{OCH}_{\mathrm{B}}\right), 6.42(\mathrm{~s}, 1 \mathrm{H}$, 8-H), $6.68(\mathrm{~s}, 1 \mathrm{H}, 5-\mathrm{H}), 7.22($ br t $J=7.2 \mathrm{~Hz}, 1 \mathrm{H}$, benzyl 4-H), 7.27 [dd, $J=J^{\prime}=7.2 \mathrm{~Hz}, 2 \mathrm{H}$, benzyl $\left.3(5)-\mathrm{H}\right], 7.36[\mathrm{br} \mathrm{d}, J=7.2 \mathrm{~Hz}, 2 \mathrm{H}$, benzyl 2(6)-H], $7.53\left(\mathrm{dd}, J=9.2 \mathrm{~Hz}, J^{\prime}=2.0 \mathrm{~Hz}, 1 \mathrm{H}, 7^{\prime \prime}-\mathrm{H}\right), 7.73(\mathrm{~d}$, $\left.J=2.0 \mathrm{~Hz}, 1 \mathrm{H}, 5^{\prime \prime}-\mathrm{H}\right), 8.34\left(\mathrm{~d}, J=9.2 \mathrm{~Hz}, 1 \mathrm{H}, 8^{\prime \prime}-\mathrm{H}\right) ;{ }^{13} \mathrm{C} \mathrm{NMR}$ $\left(100.6 \mathrm{MHz}, \mathrm{CD}_{3} \mathrm{OD}\right) \delta 21.8\left(\mathrm{CH}_{2}, \mathrm{C}^{\prime \prime}\right), 22.5\left(\mathrm{CH}_{2}, \mathrm{C} 4\right), 22.8$ $\left(\mathrm{CH}_{2}, \mathrm{C2}{ }^{\prime \prime}\right), 24.56\left(\mathrm{CH}_{3}, 2-\mathrm{CH}_{3}\right), 24.63\left(\mathrm{CH}_{2}, \mathrm{Cl}{ }^{\prime \prime}\right), 27.7\left(\mathrm{CH}_{2}\right.$, $\left.\mathrm{C}^{\prime}\right), 27.9\left(\mathrm{CH}_{2}, \mathrm{C6}^{\prime}\right), 29.3\left(\mathrm{CH}_{2}, \mathrm{C}^{\prime \prime}\right), 30.2\left(\mathrm{CH}_{2}\right), 30.3\left(\mathrm{CH}_{2}\right)$, $30.4\left(\mathrm{CH}_{2}\right), 30.5\left(\mathrm{CH}_{2}\right)\left(\mathrm{C}^{\prime}, \mathrm{C}^{\prime}, \mathrm{C}^{\prime}, \mathrm{C}^{\prime}\right), 31.3\left(\mathrm{CH}_{2}, \mathrm{C}^{\prime}\right), 32.1$ $\left(\mathrm{CH}_{2}, \mathrm{C} 3\right), 40.2\left(\mathrm{CH}_{2}, \mathrm{Cl}^{\prime}\right), 47.7\left(\mathrm{CH}_{2}, 2-\mathrm{CH}_{2}-\mathrm{CO}\right), 49.3\left(\mathrm{CH}_{2}\right.$,
$\left.\mathrm{C}^{\prime}\right), 56.4\left(\mathrm{CH}_{3}, 7-\mathrm{OCH}_{3}\right), 73.5\left(\mathrm{CH}_{2}, 6-\mathrm{OCH}_{2}\right), 75.9$ (C, $\left.\mathrm{C} 2\right)$, 103.0 (CH, C8), 113.2 (C, C9a"), 113.3 (C, C4a), 115.4 (C, C8a"), $117.6(\mathrm{CH}, \mathrm{C5}), 119.2\left(\mathrm{CH}, \mathrm{C5}^{\prime \prime}\right), 126.7\left(\mathrm{CH}, \mathrm{C}^{\prime \prime}\right), 128.78(\mathrm{CH}$, C8"), 128.81 [3CH, benzyl C2(6), benzyl C4], 129.3 [2CH, benzyl C3(5) ], 139.0 (C, benzyl C1), 140.1 (C, C6"), 140.6 (C, C10a"), 143.4 (C, C6), 149.3 (C, C8a), 150.9 (C, C7), 152.0 (C, C4a"), 157.7 (C, C9"), 172.3 (C, CONH); HRMS (ESI) calcd for $\left(\mathrm{C}_{42} \mathrm{H}_{52}{ }^{35} \mathrm{ClN}_{3} \mathrm{O}_{4}+\mathrm{H}^{+}\right)$: 698.3719, found 698.3714; HPLC purity $97 \%$.

$N$-\{6-[(6-Chloro-1,2,3,4-tetrahydroacridin-9-yl)amino]hexyl\}-2(6-benzyloxy-7-methoxy-2-methylchroman-2-yl)acetamide (11e). It was prepared as described for 4a. From carboxylic acid 8 (100 $\mathrm{mg}, 0.29 \mathrm{mmol}$ ) and amine $10 \mathrm{e}(107 \mathrm{mg}, 0.32 \mathrm{mmol})$, a brown solid $(463 \mathrm{mg}$ ) was obtained and subjected to column chromatography purification (35-70 $\mu \mathrm{m}$ silica gel, $\mathrm{CH}_{2} \mathrm{Cl}_{2} / \mathrm{MeOH} / 50 \%$ aq $\mathrm{NH}_{4} \mathrm{OH}$ mixtures, gradient elution). On elution with $\mathrm{CH}_{2} \mathrm{Cl}_{2} / \mathrm{MeOH} / 50 \%$ aq $\mathrm{NH}_{4} \mathrm{OH}$ 100:0:0.4, amide 11e (191 mg, quantitative yield) was isolated as a light yellow solid; $R_{f} 0.73\left(\mathrm{CH}_{2} \mathrm{Cl}_{2} / \mathrm{MeOH} / 50 \%\right.$ aq $\mathrm{NH}_{4} \mathrm{OH}$ 90:10:1).

11e.HCl: light yellow solid; mp $126-128{ }^{\circ} \mathrm{C}$; IR (ATR) $\nu 3600-$ 2200 ( $\max$ at $3250,3048,2928,2852, \mathrm{~N}-\mathrm{H}, \mathrm{N}^{+}-\mathrm{H}, \mathrm{C}-\mathrm{H}$ st), 1632 1573, $1510(\mathrm{C}=\mathrm{O}, \mathrm{Ar}-\mathrm{C}-\mathrm{C}, \mathrm{Ar}-\mathrm{C}-\mathrm{N} \mathrm{st}) \mathrm{cm}^{-1} ;{ }^{1} \mathrm{H}$ NMR (400 $\left.\mathrm{MHz}, \mathrm{CD}_{3} \mathrm{OD}\right) \delta 1.31\left(\mathrm{~s}, 3 \mathrm{H}, 2-\mathrm{CH}_{3}\right.$ ), 1.34-1.44 (complex signal, $\left.4 \mathrm{H}, 3^{\prime}-\mathrm{H}_{2}, 4^{\prime}-\mathrm{H}_{2}\right), 1.51\left(\mathrm{tt}, J=J^{\prime}=6.8 \mathrm{~Hz}, 2 \mathrm{H}, 2^{\prime}-\mathrm{H}_{2}\right), 1.70(\mathrm{tt}, J=$ $\left.7.2 \mathrm{~Hz}, J^{\prime}=6.8 \mathrm{~Hz}, 2 \mathrm{H}, 5^{\prime}-\mathrm{H}_{2}\right), 1.80\left(\mathrm{dt}, J=13.6 \mathrm{~Hz}, J^{\prime}=6.0 \mathrm{~Hz}, 1 \mathrm{H}\right.$, $\left.3-\mathrm{H}_{\mathrm{A}}\right)$, superimposed in part $1.93\left(\mathrm{dt}, J=13.6 \mathrm{~Hz}, J^{\prime}=6.0 \mathrm{~Hz}, 1 \mathrm{H}, 3-\right.$ $\mathrm{H}_{\mathrm{B}}$ ), 1.85-1.96 (complex signal, $\left.4 \mathrm{H}, 2^{\prime \prime}-\mathrm{H}_{2}, 3^{\prime \prime}-\mathrm{H}_{2}\right), 2.45$ (d, $J=13.6$ $\left.\mathrm{Hz}, 1 \mathrm{H}, 2-\mathrm{CH}_{\mathrm{A}}-\mathrm{CO}\right), 2.53\left(\mathrm{~d}, J=13.6 \mathrm{~Hz}, 1 \mathrm{H}, 2-\mathrm{CH}_{\mathrm{B}}-\mathrm{CO}\right)$, superimposed in part $2.61\left(\mathrm{~m}, 2 \mathrm{H}, 4-\mathrm{H}_{2}\right), 2.65(\mathrm{brt}, J=6.4 \mathrm{~Hz}, 2 \mathrm{H}$, $\left.1^{\prime \prime}-\mathrm{H}_{2}\right), 2.90\left(\mathrm{t}, J=5.6 \mathrm{~Hz}, 2 \mathrm{H}, 4^{\prime \prime}-\mathrm{H}_{2}\right), 3.14\left(\mathrm{dt}, J=13.6 \mathrm{~Hz}, J^{\prime}=6.8\right.$ $\left.\mathrm{Hz}, 1 \mathrm{H}, 1^{\prime}-\mathrm{H}_{\mathrm{A}}\right), 3.28\left(\mathrm{dt}, J=13.6 \mathrm{~Hz}, J^{\prime}=6.8 \mathrm{~Hz}, 1 \mathrm{H}, 1^{\prime}-\mathrm{H}_{\mathrm{B}}\right), 3.75(\mathrm{~s}$, $\left.3 \mathrm{H}, 7-\mathrm{OCH}_{3}\right), 3.80\left(\mathrm{t}, J=7.2 \mathrm{~Hz}, 2 \mathrm{H}, 6^{\prime}-\mathrm{H}_{2}\right), 4.83(\mathrm{~d}, J=12.0 \mathrm{~Hz}$, $\left.1 \mathrm{H}, 6-\mathrm{OCH}_{\mathrm{A}}\right), 4.85\left(\mathrm{~s}, \mathrm{NH},{ }^{+} \mathrm{NH}\right), 4.91(\mathrm{~d}, J=12.0 \mathrm{~Hz}, 1 \mathrm{H}, 6-$ $\left.\mathrm{OCH}_{\mathrm{B}}\right), 6.40(\mathrm{~s}, 1 \mathrm{H}, 8-\mathrm{H}), 6.62(\mathrm{~s}, 1 \mathrm{H}, 5-\mathrm{H}), 7.22-7.31$ [complex signal, $3 \mathrm{H}$, benzyl 3(5)-H, benzyl 4-H], $7.35\left[\mathrm{dd}, J=8.0 \mathrm{~Hz}, J^{\prime}=1.6\right.$ $\mathrm{Hz}, 2 \mathrm{H}$, benzyl $2(6)-\mathrm{H}], 7.52\left(\mathrm{dd}, J=9.2 \mathrm{~Hz}, J^{\prime}=2.0 \mathrm{~Hz}, 1 \mathrm{H}, 7^{\prime \prime}-\mathrm{H}\right)$, $7.71\left(\mathrm{~d}, J=2.0 \mathrm{~Hz}, 1 \mathrm{H}, 5^{\prime \prime}-\mathrm{H}\right), 8.28\left(\mathrm{~d}, J=9.2 \mathrm{~Hz}, 1 \mathrm{H}, 8^{\prime \prime}-\mathrm{H}\right) ;{ }^{13} \mathrm{C}$ NMR (100.6 MHz, CD $\left.{ }_{3} \mathrm{OD}\right) \delta 21.7\left(\mathrm{CH}_{2}, \mathrm{C}^{\prime \prime}\right), 22.4\left(\mathrm{CH}_{2}, \mathrm{C} 4\right)$, $22.8\left(\mathrm{CH}_{2}, \mathrm{C}^{\prime \prime}\right), 24.56\left(\mathrm{CH}_{2}, \mathrm{Cl} 1^{\prime \prime}\right), 24.64\left(\mathrm{CH}_{3}, 2-\mathrm{CH}_{3}\right), 27.36$ $\left(\mathrm{CH}_{2}\right), 27.39\left(\mathrm{CH}_{2}\right)\left(\mathrm{C}^{\prime}, \mathrm{C}^{\prime}\right), 29.2\left(\mathrm{CH}_{2}, \mathrm{C}^{\prime \prime}\right), 30.3\left(\mathrm{CH}_{2}, \mathrm{C}^{\prime}\right)$, $31.3\left(\mathrm{CH}_{2}, \mathrm{C5}^{\prime}\right), 31.9\left(\mathrm{CH}_{2}, \mathrm{C} 3\right), 40.0\left(\mathrm{CH}_{2}, \mathrm{Cl}^{\prime}\right), 47.8\left(\mathrm{CH}_{2}, 2-\right.$ $\left.\mathrm{CH}_{2}-\mathrm{CO}\right), 49.3\left(\mathrm{CH}_{2}, \mathrm{C6}^{\prime}\right), 56.5\left(\mathrm{CH}_{3}, 7-\mathrm{OCH}_{3}\right), 73.5\left(\mathrm{CH}_{2}, 6-\right.$ $\left.\mathrm{OCH}_{2}\right), 75.9$ (C, C2), 103.1 ( $\left.\mathrm{CH}, \mathrm{C} 8\right), 113.2$ (2C, C4a, C9a"), 115.3 (C, C8a"), $117.7(\mathrm{CH}, \mathrm{C5}), 119.1\left(\mathrm{CH}, \mathrm{C5}^{\prime \prime}\right), 126.7\left(\mathrm{CH}, \mathrm{C}^{\prime \prime}\right)$, 128.7 [3CH, benzyl C2(6), benzyl C4], $128.8(\mathrm{CH}, \mathrm{C} 8 "), 129.3$ [2CH, benzyl C3(5)], 138.9 (C, benzyl C1), 140.0 (C, C6"), 140.4 (C, C10a"), 143.3 (C, C6), 149.3 (C, C8a), 150.9 (C, C7), 151.9 (C, C4a"), 157.5 (C, C9"), 172.3 (C, CONH); HRMS (ESI) calcd for $\left(\mathrm{C}_{39} \mathrm{H}_{46}{ }^{35} \mathrm{ClN}_{3} \mathrm{O}_{4}+\mathrm{H}^{+}\right)$: 656.3249, found 656.3238; HPLC purity $99 \%$.

$N-\{7-[(1,2,3,4-T e t r a h y d r o a c r i d i n-9-y l) a m i n o] h e p t y l\}-2-(6-h y-$ droxy-7-methoxy-2-methylchroman-2-yl)acetamide (12a). A solution of amide 11a (123 mg, $0.19 \mathrm{mmol})$ in degassed EtOH $(3 \mathrm{~mL})$ was added to a suspension of $10 \% \mathrm{w} / \mathrm{w} \mathrm{Pd} / \mathrm{C}$ in $\mathrm{EtOH}(1.5 \mathrm{~mL})$. The mixture was stirred at $\mathrm{rt}$ and atmospheric pressure of $\mathrm{H}_{2}$ overnight. An additional portion of catalyst was added, and the mixture was allowed to react under the same conditions overnight. The resulting mixture was filtered through a plug of Celite and washed with EtOH $(3 \times 5$ $\mathrm{mL})$. The filtrate was evaporated in vacuo to afford hybrid 12a (73 $\mathrm{mg}, 72 \%$ yield $)$ as a light yellow solid; $R_{f} 0.27\left(\mathrm{CH}_{2} \mathrm{Cl}_{2} / \mathrm{MeOH} / 50 \%\right.$ aq $\mathrm{NH}_{4} \mathrm{OH}$ 95:5:1).

12a $\cdot \mathrm{HCl}$ : light yellow solid; $\mathrm{mp} 115-118^{\circ} \mathrm{C}$; IR (ATR) $\nu$ 36002200 ( $\max$ at 3248, 3092, 2930, 2852, N-H, N+ $-\mathrm{H}, \mathrm{O}-\mathrm{H}, \mathrm{C}-\mathrm{H}$ st), $1634,1574,1520(\mathrm{C}=\mathrm{O}, \mathrm{Ar}-\mathrm{C}-\mathrm{C}, \mathrm{Ar}-\mathrm{C}-\mathrm{N}$ st $) \mathrm{cm}^{-1} ;{ }^{1} \mathrm{H}$ NMR $\left(400 \mathrm{MHz}, \mathrm{CD}_{3} \mathrm{OD}\right) \delta 1.31$ (s, 3H, 2- $\mathrm{CH}_{3}$ ), 1.32-1.41 (complex signal, $\left.6 \mathrm{H}, 3^{\prime}-\mathrm{H}_{2}, 4^{\prime}-\mathrm{H}_{2}, 5^{\prime}-\mathrm{H}_{2}\right), 1.49\left(\mathrm{tt}, J=J^{\prime}=7.2 \mathrm{~Hz}, 2 \mathrm{H}, 2^{\prime}-\mathrm{H}_{2}\right)$, 1.72-1.82 (complex signal, $\left.3 \mathrm{H}, 3-\mathrm{H}_{\mathrm{A}}, 6^{\prime}-\mathrm{H}_{2}\right), 1.83-1.91(\mathrm{~m}, 1 \mathrm{H}, 3-$ $\mathrm{H}_{\mathrm{B}}$ ), 1.92-2.00 (complex signal, $\left.4 \mathrm{H}, 2^{\prime \prime}-\mathrm{H}_{2}, 3^{\prime \prime}-\mathrm{H}_{2}\right), 2.44(\mathrm{~d}, J=13.6$ $\left.\mathrm{Hz}, 1 \mathrm{H}, 2-\mathrm{CH}_{\mathrm{A}}-\mathrm{CO}\right), 2.49\left(\mathrm{~d}, J=13.6 \mathrm{~Hz}, 1 \mathrm{H}, 2-\mathrm{CH}_{\mathrm{B}}-\mathrm{CO}\right), 2.62(\mathrm{t}, J$ $\left.=6.0 \mathrm{~Hz}, 2 \mathrm{H}, 4-\mathrm{H}_{2}\right), 2.68\left(\mathrm{t}, J=5.6 \mathrm{~Hz}, 2 \mathrm{H}, 1^{\prime \prime}-\mathrm{H}_{2}\right), 3.00(\mathrm{t}, J=6.0$ 
$\left.\mathrm{Hz}, 2 \mathrm{H}, 4^{\prime \prime}-\mathrm{H}_{2}\right), 3.18\left(\mathrm{~m}, 2 \mathrm{H}, 1^{\prime}-\mathrm{H}_{2}\right), 3.74\left(\mathrm{~s}, 3 \mathrm{H}, 7-\mathrm{OCH}_{3}\right), 3.91(\mathrm{t}, J$ $\left.=7.2 \mathrm{~Hz}, 2 \mathrm{H}, 7^{\prime}-\mathrm{H}_{2}\right), 4.85\left(\mathrm{~s}, \mathrm{NH},{ }^{+} \mathrm{NH}, \mathrm{OH}\right), 6.33(\mathrm{~s}, 1 \mathrm{H}, 8-\mathrm{H})$, $6.45(\mathrm{~s}, 1 \mathrm{H}, 5-\mathrm{H}), 7.58\left(\mathrm{ddd}, J=8.8 \mathrm{~Hz}, J^{\prime}=7.2 \mathrm{~Hz}, J^{\prime \prime}=1.2 \mathrm{~Hz}, 1 \mathrm{H}\right.$, $\left.7^{\prime \prime}-\mathrm{H}\right), 7.74\left(\mathrm{dd}, J=8.4 \mathrm{~Hz}, J^{\prime}=1.2 \mathrm{~Hz}, 1 \mathrm{H}, 5^{\prime \prime}-\mathrm{H}\right), 7.84(\mathrm{ddd}, J=8.4$ $\left.\mathrm{Hz}, J^{\prime}=7.2 \mathrm{~Hz}, J^{\prime \prime}=1.2 \mathrm{~Hz}, 1 \mathrm{H}, 6^{\prime \prime}-\mathrm{H}\right), 8.37\left(\mathrm{~d}, J=8.8 \mathrm{~Hz}, 1 \mathrm{H}, 8^{\prime \prime}-\right.$ $\mathrm{H}) ;{ }^{13} \mathrm{C}$ NMR (100.6 MHz, CD $\left.\mathrm{OD}\right) \delta 21.8\left(\mathrm{CH}_{2}, \mathrm{C} 3 "\right), 22.4\left(\mathrm{CH}_{2}\right.$ C4), $23.0\left(\mathrm{CH}_{2}, \mathrm{C} 2^{\prime \prime}\right), 24.4\left(\mathrm{CH}_{3}, 2-\mathrm{CH}_{3}\right), 24.9\left(\mathrm{CH}_{2}, \mathrm{Cl}^{\prime \prime}\right), 27.6$ $\left(\mathrm{CH}_{2}, \mathrm{C5}^{\prime}\right), 27.7\left(\mathrm{CH}_{2}, \mathrm{C}^{\prime}\right), 29.3\left(\mathrm{CH}_{2}, \mathrm{C}^{\prime \prime}\right), 29.9\left(\mathrm{CH}_{2}, \mathrm{C}^{\prime}\right)$, $30.2\left(\mathrm{CH}_{2}, \mathrm{C}^{\prime}\right)$, $31.4\left(\mathrm{CH}_{2}, \mathrm{C}^{\prime}\right), 32.3\left(\mathrm{CH}_{2}, \mathrm{C} 3\right), 40.4\left(\mathrm{CH}_{2}, \mathrm{Cl}^{\prime}\right)$, $47.3\left(\mathrm{CH}_{2}, 2-\mathrm{CH}_{2}-\mathrm{CO}\right), 49.1\left(\mathrm{CH}, \mathrm{C}^{\prime}\right), 56.4\left(\mathrm{CH}_{3}, 7-\mathrm{OCH}_{3}\right), 75.5$ (C, C2), $102.2(\mathrm{CH}, \mathrm{C} 8), 112.8$ (C, C9a"), 113.3 (C, C4a), 116.1 (CH, C5), 117.0 (C, C8a"), $120.1\left(\mathrm{CH}, \mathrm{C5}^{\prime \prime}\right), 126.3\left(\mathrm{CH}, \mathrm{C7}^{\prime \prime}\right)$, $126.5\left(\mathrm{CH}, \mathrm{C} 8^{\prime \prime}\right), 134.0(\mathrm{CH}, \mathrm{C} 6 "), 139.7\left(\mathrm{C}, \mathrm{C} 10 a^{\prime \prime}\right), 141.1$ (C, C6), 147.3 (C, C8a), 148.3 (C, C7), 151.6 (C, C4a"), 157.9 (C, C9"), 172.7 (C, CONH); HRMS (ESI) calcd for $\left(\mathrm{C}_{33} \mathrm{H}_{43} \mathrm{~N}_{3} \mathrm{O}_{4}+\right.$ $\left.\mathrm{H}^{+}\right)$: 546.3332, found 546.3290; HPLC purity $100 \%$.

$N$-\{8-[(1,2,3,4-Tetrahydroacridin-9-yl)amino]octyl\}-2-(6-hydroxy7-methoxy-2-methylchroman-2-yl)acetamide (12b). It was prepared as described for 12a. From $11 \mathbf{b}(56 \mathrm{mg}, 0.08 \mathrm{mmol})$, amide 12b (46 mg, 99\% yield) was isolated as a light green solid; $R_{f} 0.26$ $\left(\mathrm{CH}_{2} \mathrm{Cl}_{2} / \mathrm{MeOH} / 50 \%\right.$ aq $\mathrm{NH}_{4} \mathrm{OH}$ 95:5:1).

12b· HCl: light green solid; mp $104-107{ }^{\circ} \mathrm{C}$; IR (ATR) $\nu$ 36002200 ( $\max$ at $3249,3090,2927,2852, \mathrm{~N}-\mathrm{H}, \mathrm{N}^{+}-\mathrm{H}, \mathrm{O}-\mathrm{H}, \mathrm{C}-\mathrm{H}$ st), 1634, 1575, 1519 (C=O, Ar-C-C, Ar-C-N st) $\mathrm{cm}^{-1} ;{ }^{1} \mathrm{H}$ NMR $\left(400 \mathrm{MHz}, \mathrm{CD}_{3} \mathrm{OD}\right) \delta 1.25-1.34$ (complex signal, 9H, 2- $\mathrm{CH}_{3}, 3^{\prime}-\mathrm{H}_{2}$, $\left.4^{\prime}-\mathrm{H}_{2}, 5^{\prime}-\mathrm{H}_{2}\right), 1.38\left(\mathrm{~m}, 2 \mathrm{H}, 6^{\prime}-\mathrm{H}_{2}\right), 1.47\left(\mathrm{~m}, 2 \mathrm{H}, 2^{\prime}-\mathrm{H}_{2}\right), 1.72-1.84$ (complex signal, $\left.3 \mathrm{H}, 3-\mathrm{H}_{\mathrm{A}}, 7^{\prime}-\mathrm{H}_{2}\right), 1.87\left(\mathrm{~m}, 1 \mathrm{H}, 3-\mathrm{H}_{\mathrm{B}}\right), 1.91-2.01$ (complex signal, $\left.4 \mathrm{H}, 2^{\prime \prime}-\mathrm{H}_{2}, 3^{\prime \prime}-\mathrm{H}_{2}\right), 2.44\left(\mathrm{~d}, J=13.2 \mathrm{~Hz}, 1 \mathrm{H}, 2-\mathrm{CH}_{\mathrm{A}^{-}}\right.$ $\mathrm{CO}), 2.48\left(\mathrm{~d}, J=13.2 \mathrm{~Hz}, 1 \mathrm{H}, 2-\mathrm{CH}_{\mathrm{B}}-\mathrm{CO}\right), 2.62(\mathrm{t}, J=6.4 \mathrm{~Hz}, 2 \mathrm{H}$, $\left.4-\mathrm{H}_{2}\right), 2.69\left(\mathrm{t}, J=5.6 \mathrm{~Hz}, 2 \mathrm{H}, 1^{\prime \prime}-\mathrm{H}_{2}\right), 3.00\left(\mathrm{t}, J=6.0 \mathrm{~Hz}, 2 \mathrm{H}, 4^{\prime \prime}-\mathrm{H}_{2}\right)$, $3.17\left(\mathrm{~m}, 2 \mathrm{H}, 1^{\prime}-\mathrm{H}_{2}\right), 3.75\left(\mathrm{~s}, 3 \mathrm{H}, 7-\mathrm{OCH}_{3}\right), 3.91(\mathrm{t}, J=7.2 \mathrm{~Hz}, 2 \mathrm{H}$, $\left.8^{\prime}-\mathrm{H}_{2}\right), 4.85\left(\mathrm{~s}, \mathrm{NH},{ }^{+} \mathrm{NH}, \mathrm{OH}\right), 6.34(\mathrm{~s}, 1 \mathrm{H}, 8-\mathrm{H}), 6.45(\mathrm{~s}, 1 \mathrm{H}, 5-\mathrm{H})$, 7.58 (ddd, $\left.J=8.8 \mathrm{~Hz}, J^{\prime}=7.2 \mathrm{~Hz}, J^{\prime \prime}=1.2 \mathrm{~Hz}, 1 \mathrm{H}, 7^{\prime \prime}-\mathrm{H}\right), 7.74(\mathrm{dd}, J$ $\left.=8.4 \mathrm{~Hz}, J^{\prime}=1.2 \mathrm{~Hz}, 1 \mathrm{H}, 5^{\prime \prime}-\mathrm{H}\right), 7.84\left(\mathrm{ddd}, J=8.4 \mathrm{~Hz}, J^{\prime}=7.2 \mathrm{~Hz}, J^{\prime \prime}\right.$ $\left.=1.2 \mathrm{~Hz}, 1 \mathrm{H}, 6^{\prime \prime}-\mathrm{H}\right), 8.34$ (br d, $\left.J=8.8 \mathrm{~Hz}, 1 \mathrm{H}, 8^{\prime \prime}-\mathrm{H}\right) ;{ }^{13} \mathrm{C}$ NMR $\left(100.6 \mathrm{MHz}, \mathrm{CD}_{3} \mathrm{OD}\right) \delta 21.8\left(\mathrm{CH}_{2}, \mathrm{C}^{\prime \prime}\right), 22.4\left(\mathrm{CH}_{2}, \mathrm{C} 4\right), 23.0$ $\left(\mathrm{CH}_{2}, \mathrm{C2}{ }^{\prime \prime}\right), 24.5\left(\mathrm{CH}_{3}, 2-\mathrm{CH}_{3}\right), 24.8\left(\mathrm{CH}_{2}, \mathrm{Cl}^{\prime \prime}\right), 27.6\left(\mathrm{CH}_{2}, \mathrm{C6}^{\prime}\right)$, $27.7\left(\mathrm{CH}_{2}, \mathrm{C5}^{\prime}\right), 29.3\left(\mathrm{CH}_{2}, \mathrm{C}^{\prime \prime}\right), 30.1\left(\mathrm{CH}_{2}\right), 30.2\left(\mathrm{CH}_{2}\right)\left(\mathrm{C}^{\prime}\right.$, $\left.\mathrm{C}^{\prime}\right), 30.3\left(\mathrm{CH}_{2}, \mathrm{C}^{\prime}\right), 31.5\left(\mathrm{CH}_{2}, \mathrm{C}^{\prime}\right), 32.3\left(\mathrm{CH}_{2}, \mathrm{C} 3\right), 40.3\left(\mathrm{CH}_{2}\right.$, $\left.\mathrm{Cl}^{\prime}\right)$, $47.4\left(\mathrm{CH}_{2}, 2-\mathrm{CH}_{2}-\mathrm{CO}\right), 49.2\left(\mathrm{CH}, \mathrm{C}^{\prime}\right), 56.4\left(\mathrm{CH}_{3}, 7-\mathrm{OCH}_{3}\right)$, 75.6 (C, C2), $102.2(\mathrm{CH}, \mathrm{C} 8), 112.8$ (C, C9a"), 113.3 (C, C4a), $116.1(\mathrm{CH}, \mathrm{C} 5), 117.0\left(\mathrm{C}, \mathrm{C} 8 \mathrm{a}^{\prime \prime}\right), 120.1\left(\mathrm{CH}, \mathrm{C}^{\prime \prime}\right), 126.3(\mathrm{CH}$, $\left.\mathrm{C}^{\prime \prime}\right), 126.5$ (CH, C8"), $134.1\left(\mathrm{CH}, \mathrm{C6}^{\prime \prime}\right), 139.7$ (C, C10a"), 141.1 (C, C6), 147.3 (C, C8a), 148.3 (C, C7), 151.6 (C, C4a"), 157.9 (C, C9"), 172.6 (C, CONH); HRMS (ESI) calcd for $\left(\mathrm{C}_{34} \mathrm{H}_{45} \mathrm{~N}_{3} \mathrm{O}_{4}+\right.$ $\left.\mathrm{H}^{+}\right)$: 560.3488, found 560.3496; HPLC purity $97 \%$.

$N$-\{9-[(1,2,3,4-Tetrahydroacridin-9-yl)amino]nonyl\}-2-(6-hydroxy-7-methoxy-2-methylchroman-2-yl)acetamide (12c). It was prepared as described for 12a. From 11c (65 mg, $0.09 \mathrm{mmol})$, amide $12 \mathrm{c}$ ( $53 \mathrm{mg}, 99 \%$ yield) was isolated as a light yellow solid; $R_{f} 0.25$ $\left(\mathrm{CH}_{2} \mathrm{Cl}_{2} / \mathrm{MeOH} / 50 \%\right.$ aq $\mathrm{NH}_{4} \mathrm{OH}$ 95:5:1).

12c. HCl: light yellow solid; $\mathrm{mp} 105-108{ }^{\circ} \mathrm{C}$; IR (ATR) $\nu$ 36002200 ( $\max$ at $3250,3098,2929,2852, \mathrm{~N}-\mathrm{H}, \mathrm{N}^{+}-\mathrm{H}, \mathrm{O}-\mathrm{H}, \mathrm{C}-\mathrm{H}$ st), 1633, 1572, 1515 (C=O, Ar-C-C, Ar-C-N st) $\mathrm{cm}^{-1} ;{ }^{1} \mathrm{H}$ NMR $\left(400 \mathrm{MHz}, \mathrm{CD}_{3} \mathrm{OD}\right) \delta 1.21-1.35$ (complex signal, $11 \mathrm{H}, 2-\mathrm{CH}_{3}, 3^{\prime}-$ $\left.\mathrm{H}_{2}, 4^{\prime}-\mathrm{H}_{2}, 5^{\prime}-\mathrm{H}_{2}, 6^{\prime}-\mathrm{H}_{2}\right), 1.39\left(\mathrm{~m}, 2 \mathrm{H}, 7^{\prime}-\mathrm{H}_{2}\right), 1.47\left(\mathrm{tt}, J=J^{\prime}=6.8\right.$ $\mathrm{Hz}, 2 \mathrm{H}, 2^{\prime}-\mathrm{H}_{2}$ ), $1.73-1.90$ (complex signal, $4 \mathrm{H}, 3-\mathrm{H}_{2}, 8^{\prime}-\mathrm{H}_{2}$ ), $1.93-$ 2.02 (complex signal, $\left.4 \mathrm{H}, 2^{\prime \prime}-\mathrm{H}_{2}, 3^{\prime \prime}-\mathrm{H}_{2}\right), 2.44(\mathrm{~d}, J=13.6 \mathrm{~Hz}, 1 \mathrm{H}, 2$ $\left.\mathrm{CH}_{\mathrm{A}}-\mathrm{CO}\right), 2.49\left(\mathrm{~d}, J=13.6 \mathrm{~Hz}, 1 \mathrm{H}, 2-\mathrm{CH}_{\mathrm{B}}-\mathrm{CO}\right), 2.63(\mathrm{t}, J=6.8 \mathrm{~Hz}$, $\left.2 \mathrm{H}, 4-\mathrm{H}_{2}\right), 2.70\left(\mathrm{t}, J=5.2 \mathrm{~Hz}, 2 \mathrm{H}, 1^{\prime \prime}-\mathrm{H}_{2}\right), 3.01\left(\mathrm{t}, J=6.8 \mathrm{~Hz}, 2 \mathrm{H}, 4^{\prime \prime}-\right.$ $\left.\mathrm{H}_{2}\right), 3.18\left(\mathrm{~m}, 2 \mathrm{H}, 1^{\prime}-\mathrm{H}_{2}\right), 3.76\left(\mathrm{~s}, 3 \mathrm{H}, 7-\mathrm{OCH}_{3}\right), 3.93(\mathrm{t}, J=7.2 \mathrm{~Hz}$, $\left.2 \mathrm{H}, 9^{\prime}-\mathrm{H}_{2}\right), 4.85\left(\mathrm{~s}, \mathrm{NH},{ }^{+} \mathrm{NH}, \mathrm{OH}\right), 6.34(\mathrm{~s}, 1 \mathrm{H}, 8-\mathrm{H}), 6.45(\mathrm{~s}, 1 \mathrm{H}$, $5-\mathrm{H}), 7.58\left(\mathrm{ddd}, J=8.8 \mathrm{~Hz}, J^{\prime}=6.8 \mathrm{~Hz}, J^{\prime \prime}=1.2 \mathrm{~Hz}, 1 \mathrm{H}, 7^{\prime \prime}-\mathrm{H}\right), 7.74$ $\left(\mathrm{dd}, J=8.4 \mathrm{~Hz}, J^{\prime}=1.2 \mathrm{~Hz}, 1 \mathrm{H}, 5^{\prime \prime}-\mathrm{H}\right), 7.85\left(\mathrm{ddd}, J=8.4 \mathrm{~Hz}, J^{\prime}=6.8\right.$ $\left.\mathrm{Hz}, J^{\prime \prime}=1.2 \mathrm{~Hz}, 1 \mathrm{H}, 6^{\prime \prime}-\mathrm{H}\right), 8.39$ (br d, $\left.J=8.8 \mathrm{~Hz}, 1 \mathrm{H}, 8^{\prime \prime}-\mathrm{H}\right) ;{ }^{13} \mathrm{C}$ NMR (100.6 MHz, $\left.\mathrm{CD}_{3} \mathrm{OD}\right) \delta 21.8\left(\mathrm{CH}_{2}, \mathrm{C}^{\prime \prime}\right), 22.4\left(\mathrm{CH}_{2}, \mathrm{C} 4\right)$, $23.0\left(\mathrm{CH}_{2}, \mathrm{C2}{ }^{\prime \prime}\right), 24.4\left(\mathrm{CH}_{3}, 2-\mathrm{CH}_{3}\right), 24.9\left(\mathrm{CH}_{2}, \mathrm{Cl}^{\prime \prime}\right), 27.6\left(\mathrm{CH}_{2}\right.$, $\left.\mathrm{C}^{\prime}\right), 27.8\left(\mathrm{CH}_{2}, \mathrm{C}^{\prime}\right), 29.3\left(\mathrm{CH}_{2}, \mathrm{C}^{\prime \prime}\right), 30.1\left(\mathrm{CH}_{2}\right), 30.2\left(2 \mathrm{CH}_{2}\right)$ $\left(\mathrm{C}^{\prime}, \mathrm{C}^{\prime}, \mathrm{C}^{\prime}\right), 30.4\left(\mathrm{CH}_{2}, \mathrm{C}^{\prime}\right), 31.5\left(\mathrm{CH}_{2}, \mathrm{C}^{\prime}\right), 32.3\left(\mathrm{CH}_{2}, \mathrm{C} 3\right)$, $40.6\left(\mathrm{CH}_{2}, \mathrm{Cl}^{\prime}\right), 47.2\left(\mathrm{CH}_{2}, 2-\mathrm{CH}_{2}-\mathrm{CO}\right), 49.2\left(\mathrm{CH}, \mathrm{C}^{\prime}\right), 56.4$
$\left(\mathrm{CH}_{3}, 7-\mathrm{OCH}_{3}\right), 75.5(\mathrm{C}, \mathrm{C} 2), 102.2(\mathrm{CH}, \mathrm{C} 8), 112.8\left(\mathrm{C}, \mathrm{C} 9 \mathrm{a}^{\prime \prime}\right)$, 113.3 (C, C4a), 116.0 (CH, C5), 117.0 (C, C8a"), $120.1\left(\mathrm{CH}, \mathrm{C5}^{\prime \prime}\right)$, $126.3\left(\mathrm{CH}, \mathrm{C}^{\prime \prime}\right), 126.5\left(\mathrm{CH}, \mathrm{C}^{\prime \prime}\right), 134.0\left(\mathrm{CH}, \mathrm{C6}^{\prime \prime}\right), 139.7$ (C, C10a"), 141.1 (C, C6), 147.2 (C, C8a), 148.3 (C, C7), 151.6 (C, C4a"), 157.9 (C, C9"), 172.8 (C, CONH); HRMS (ESI) calcd for $\left(\mathrm{C}_{35} \mathrm{H}_{47} \mathrm{~N}_{3} \mathrm{O}_{4}+\mathrm{H}^{+}\right): 574.3645$, found 574.3655 ; HPLC purity $99 \%$.

$N$ - $\{6-[(1,2,3,4-$ Tetrahydroacridin-9-yl)amino]hexyl\}-2-(6-hydroxy-7-methoxy-2-methylchroman-2-yl)acetamide (12e). It was prepared as described for 12a. From 11 e $(43 \mathrm{mg}, 0.07 \mathrm{mmol})$, amide 12e ( $35 \mathrm{mg}, 99 \%$ yield) was isolated as a light yellow solid; $R_{f} 0.27$ $\left(\mathrm{CH}_{2} \mathrm{Cl}_{2} / \mathrm{MeOH} / 50 \%\right.$ aq $\mathrm{NH}_{4} \mathrm{OH}$ 95:5:1).

12e $\cdot \mathrm{HCl}$ : light yellow solid; $\mathrm{mp} 117-120^{\circ} \mathrm{C}$; IR (ATR) $\nu$ 36002200 ( $\max$ at $3236,3081,2930,2856, \mathrm{~N}-\mathrm{H}, \mathrm{N}^{+}-\mathrm{H}, \mathrm{O}-\mathrm{H}, \mathrm{C}-\mathrm{H}$ st), 1633, 1573, $1519(\mathrm{C}=\mathrm{O}, \mathrm{Ar}-\mathrm{C}-\mathrm{C}, \mathrm{Ar}-\mathrm{C}-\mathrm{N}$ st $) \mathrm{cm}^{-1} ;{ }^{1} \mathrm{H}$ NMR $\left(400 \mathrm{MHz}, \mathrm{CD}_{3} \mathrm{OD}\right) \delta 1.29\left(\mathrm{~s}, 3 \mathrm{H}, 2-\mathrm{CH}_{3}\right), 1.34-1.46$ (complex signal, $\left.4 \mathrm{H}, 3^{\prime}-\mathrm{H}_{2}, 4^{\prime}-\mathrm{H}_{2}\right), 1.52\left(\mathrm{tt}, J=J^{\prime}=6.8 \mathrm{~Hz}, 2 \mathrm{H}, 2^{\prime}-\mathrm{H}_{2}\right), 1.70-$ 1.81 (complex signal, $\left.3 \mathrm{H}, 3-\mathrm{H}_{\mathrm{A}}, 5^{\prime}-\mathrm{H}_{2}\right), 1.89\left(\mathrm{~m}, 1 \mathrm{H}, 3-\mathrm{H}_{\mathrm{B}}\right), 1.93-$ 2.01 (complex signal, $\left.4 \mathrm{H}, 2^{\prime \prime}-\mathrm{H}_{2}, 3^{\prime \prime}-\mathrm{H}_{2}\right), 2.43(\mathrm{~d}, J=13.2 \mathrm{~Hz}, 1 \mathrm{H}, 2-$ $\left.\mathrm{CH}_{\mathrm{A}}-\mathrm{CO}\right), 2.49\left(\mathrm{~d}, J=13.2 \mathrm{~Hz}, 1 \mathrm{H}, 2-\mathrm{CH}_{\mathrm{B}}-\mathrm{CO}\right), 2.59(\mathrm{~m}, 2 \mathrm{H}, 4-$ $\left.\mathrm{H}_{2}\right), 2.68\left(\mathrm{t}, J=5.6 \mathrm{~Hz}, 2 \mathrm{H}, 1^{\prime \prime}-\mathrm{H}_{2}\right), 3.00\left(\mathrm{t}, J=6.0 \mathrm{~Hz}, 2 \mathrm{H}, 4^{\prime \prime}-\mathrm{H}_{2}\right)$, $3.20\left(\mathrm{~m}, 2 \mathrm{H}, 1^{\prime}-\mathrm{H}_{2}\right), 3.72\left(\mathrm{~s}, 3 \mathrm{H}, 7-\mathrm{OCH}_{3}\right), 3.85(\mathrm{t}, J=7.6 \mathrm{~Hz}, 2 \mathrm{H}$, $\left.6^{\prime}-\mathrm{H}_{2}\right), 4.85\left(\mathrm{~s}, \mathrm{NH},{ }^{+} \mathrm{NH}, \mathrm{OH}\right), 6.32(\mathrm{~s}, 1 \mathrm{H}, 8-\mathrm{H}), 6.41(\mathrm{~s}, 1 \mathrm{H}, 5-\mathrm{H})$, 7.57 (ddd, $\left.J=8.8 \mathrm{~Hz}, J^{\prime}=7.2 \mathrm{~Hz}, J^{\prime \prime}=1.2 \mathrm{~Hz}, 1 \mathrm{H}, 7^{\prime \prime}-\mathrm{H}\right), 7.73(\mathrm{dd}, J$ $\left.=8.4 \mathrm{~Hz}, J^{\prime}=1.2 \mathrm{~Hz}, 1 \mathrm{H}, 5^{\prime \prime}-\mathrm{H}\right), 7.84\left(\mathrm{ddd}, J=8.4 \mathrm{~Hz}, J^{\prime}=7.2 \mathrm{~Hz}, J^{\prime \prime}\right.$ $\left.=1.2 \mathrm{~Hz}, 1 \mathrm{H}, 6^{\prime \prime}-\mathrm{H}\right), 8.34\left(\mathrm{br} \mathrm{d}, J=8.8 \mathrm{~Hz}, 1 \mathrm{H}, 8^{\prime \prime}-\mathrm{H}\right) ;{ }^{13} \mathrm{C}$ NMR $\left(100.6 \mathrm{MHz}, \mathrm{CD}_{3} \mathrm{OD}\right) \delta 21.8\left(\mathrm{CH}_{2}, \mathrm{C}^{\prime \prime}\right), 22.4\left(\mathrm{CH}_{2}, \mathrm{C} 4\right), 23.0$ $\left(\mathrm{CH}_{2}, \mathrm{C} 2^{\prime \prime}\right), 24.5\left(\mathrm{CH}_{3}, 2-\mathrm{CH}_{3}\right), 24.8\left(\mathrm{CH}_{2}, \mathrm{Cl}^{\prime \prime}\right), 27.3\left(\mathrm{CH}_{2}\right), 27.4$ $\left(\mathrm{CH}_{2}\right)\left(\mathrm{C}^{\prime}, \mathrm{C}^{\prime}\right), 29.3\left(\mathrm{CH}_{2}, \mathrm{C} 4^{\prime \prime}\right), 30.2\left(\mathrm{CH}_{2}, \mathrm{C} 2^{\prime}\right), 31.4\left(\mathrm{CH}_{2}\right.$, $\left.\mathrm{C5}^{\prime}\right)$, $32.2\left(\mathrm{CH}_{2}, \mathrm{C} 3\right), 40.1\left(\mathrm{CH}_{2}, \mathrm{Cl}^{\prime}\right), 47.5\left(\mathrm{CH}_{2}, 2-\mathrm{CH}_{2}-\mathrm{CO}\right), 49.0$ $\left(\mathrm{CH}, \mathrm{C6}^{\prime}\right), 56.4\left(\mathrm{CH}_{3}, 7-\mathrm{OCH}_{3}\right), 75.1(\mathrm{C}, \mathrm{C} 2), 102.2(\mathrm{CH}, \mathrm{C} 8)$, 112.8 (C, C9a"), 113.4 (C, C4a), 116.1 (CH, C5), 117.0 (C, C8a"), $120.1\left(\mathrm{CH}, \mathrm{C5}^{\prime \prime}\right), 126.3\left(\mathrm{CH}, \mathrm{C}^{\prime \prime}\right), 126.5\left(\mathrm{CH}, \mathrm{C} 8^{\prime \prime}\right), 134.0(\mathrm{CH}$, C6"), 139.8 (C, C10a"), 141.1 (C, C6), 147.4 (C, C8a), 148.3 (C, C7), 151.6 (C, C4a"), 157.9 (C, C9"), 172.6 (C, CONH); HRMS (ESI) calcd for $\left(\mathrm{C}_{32} \mathrm{H}_{41} \mathrm{~N}_{3} \mathrm{O}_{4}+\mathrm{H}^{+}\right): 532.3175$, found 532.3165; HPLC purity $99 \%$.

2-(6-Hydroxy-7-methoxy-2-methylchroman-2-yl)ethyl p-Toluenesulfonate (15). A solution of O-benzyl-protected tosylate 16 $(1.07 \mathrm{~g}, 2.22 \mathrm{mmol})$ in THF $(15 \mathrm{~mL})$ was added to a suspension of $10 \% \mathrm{w} / \mathrm{w} \mathrm{Pd} / \mathrm{C}(110 \mathrm{mg})$ in degassed THF $(2 \mathrm{~mL})$ under an argon atmosphere. The resulting mixture was stirred under 1 atm of $\mathrm{H}_{2}$ overnight, then filtered through a plug of Celite, and washed with THF $(3 \times 5 \mathrm{~mL})$. The filtrate was evaporated at reduced pressure to yield tosylate 15 (782 mg, 90\% yield) as a light green solid; ${ }^{1} \mathrm{H}$ NMR $\left(400 \mathrm{MHz}, \mathrm{CDCl}_{3}\right) \delta 1.23\left(\mathrm{~s}, 3 \mathrm{H}, 2-\mathrm{CH}_{3}\right), 1.72\left(\mathrm{~m}, 2 \mathrm{H}, 3-\mathrm{H}_{2}\right), 1.91$ $(\mathrm{m}, 1 \mathrm{H}), 1.99(\mathrm{~m}, 1 \mathrm{H})\left(2-\mathrm{CH}_{2}-\mathrm{CH}_{2}-\mathrm{OTs}\right), 2.43\left(\mathrm{~s}, 3 \mathrm{H}\right.$, tosyl $\left.\mathrm{CH}_{3}\right)$, $2.62\left(\mathrm{~m}, 2 \mathrm{H}, 4-\mathrm{H}_{2}\right), 3.80\left(\mathrm{~s}, 3 \mathrm{H}, 7-\mathrm{OCH}_{3}\right), 3.97\left(\mathrm{~m}, 2 \mathrm{H}, 2-\mathrm{CH}_{2}-\mathrm{CH}_{2}-\right.$ OTs), $6.25(\mathrm{~s}, 1 \mathrm{H}, 8-\mathrm{H}), 6.56(\mathrm{~s}, 1 \mathrm{H}, 5-\mathrm{H}), 7.31[\mathrm{~d}, J=8.0 \mathrm{~Hz}, 2 \mathrm{H}$, tosyl 3(5)-H], $7.76[\mathrm{~d}, J=8.0 \mathrm{~Hz}, 2 \mathrm{H}$, tosyl $2(6)-\mathrm{H}] ;{ }^{13} \mathrm{C}$ NMR $\left(100.6 \mathrm{MHz}, \mathrm{CDCl}_{3}\right) \delta 21.4\left(\mathrm{CH}_{3}\right.$, tosyl $\left.\mathrm{CH}_{3}\right), 21.8\left(\mathrm{CH}_{2}, \mathrm{C} 4\right), 24.2$ $\left(\mathrm{CH}_{3}, 2-\mathrm{CH}_{3}\right), 31.7\left(\mathrm{CH}_{2}, \mathrm{C} 3\right), 38.2\left(\mathrm{CH}_{2}, 2-\mathrm{CH}_{2}-\mathrm{CH}_{2}-\mathrm{OTs}\right), 56.0$ $\left(\mathrm{CH}_{3}, 7-\mathrm{OCH}_{3}\right), 67.6\left(\mathrm{CH}_{2}, 2-\mathrm{CH}_{2}-\mathrm{CH}_{2}-\mathrm{OTs}\right)$, superimposed with solvent signal 76.7 (C, C2), $100.5(\mathrm{CH}, \mathrm{C} 8), 112.3$ (C, C4a), 114.2 (CH, C5), $128.0(\mathrm{CH}), 129.9(\mathrm{CH})$ (tosyl $\mathrm{CH}), 133.2(\mathrm{C}$, tosyl C4), 139.4 (C, tosyl C1), 144.9 (C, C6), 145.9 (C), 146.3 (C) (C7, C8a); HRMS (ESI) calcd for $\left(\mathrm{C}_{20} \mathrm{H}_{24} \mathrm{O}_{6} \mathrm{~S}+\mathrm{H}^{+}\right): 393.1372$, found 393.1336.

In Vitro Biological Studies and Molecular Modeling. AChE and BChE Inhibition Assay. The inhibitory activity of the target CR6-chlorotacrine hybrids toward human recombinant AChE and human serum BChE (Sigma, Milan, Italy) was evaluated spectrophotometrically by the method of Ellman et al. ${ }^{27}$ The enzyme stock solutions were prepared by dissolving enzyme lyophilized powders in $0.1 \%$ Triton X-100/0.1 M potassium phosphate, $\mathrm{pH} 8.0$ (for hAChE) or in $0.1 \%$ aq gelatin (for $\mathrm{hBChE}$ ). The stock solutions of the target compounds $(1 \mathrm{mM})$ were prepared in $\mathrm{MeOH}$. The assay solution consisted of $340 \mu \mathrm{M} 5,5^{\prime}$-dithiobis(2-nitrobenzoic acid) (DTNB), $0.02 \mathrm{unit} / \mathrm{mL} \mathrm{hAChE}$ or $\mathrm{hBChE}$, and $550 \mu \mathrm{M}$ acetylthiocholine iodide (substrate for hAChE) or butyrylthiocholine iodide (substrate for $\mathrm{hBChE}$ ) in $0.1 \mathrm{M}$ potassium phosphate, $\mathrm{pH}$ 8.0. Assay solutions 
with and without the target compounds were preincubated at $37^{\circ} \mathrm{C}$ for $20 \mathrm{~min}$, before the addition of the substrate. Blank solutions containing all components except the enzymes were prepared in parallel to correct for nonenzymatic hydrolysis of the substrates. Initial rates were monitored at $412 \mathrm{~nm}$ with a Jasco V-530 doublebeam spectrophotometer equipped with thermostated cuvette holders $\left(37^{\circ} \mathrm{C}\right)$. At least five increasing concentrations of the target compounds, which led to $20-80 \%$ inhibition of the enzymatic activities, were assayed. $\mathrm{IC}_{50}$ values were calculated using Microcal Origin 3.5 software (Microcal Software, Inc.) and are expressed as mean \pm standard error of the mean (SEM) of at least two experiments, each performed in triplicate.

Kinetic Analysis of AChE Inhibition. To estimate the mechanism of action of hybrid $\mathbf{6 b}$, Lineweaver-Burk double reciprocal plots were constructed at a relatively low concentration of substrate $(0.110-$ $0.553 \mathrm{mM}$ ) using the same experimental conditions reported for the hAChE inhibition assay. The plots were assessed by a weighted leastsquares analysis that assumed the variance of the velocity $(v)$ to be a constant percentage of $v$ for the entire data set. To confirm the mode of inhibition, the Cornish-Bowden plot was obtained by plotting $S / v$ (substrate/velocity ratio) versus inhibitor concentration. ${ }^{51}$ Data analysis was performed with GraphPad Prism 4.03 software (GraphPad Software Inc.). The mechanism of inhibition was assessed by two independent experiments, each performed in triplicate.

Calculation of the inhibitor constant $\left(K_{\mathrm{i}}\right)$ value was carried out by replotting slopes of lines from the Lineweaver-Burk plot versus the inhibitor concentration and $K_{\mathrm{i}}$ was determined as the intersect on the negative $x$-axis. The $K_{\mathrm{i}}^{\prime}$ (dissociation constant for the enzymesubstrate-inhibitor complex) value was determined by plotting the apparent $1 / v_{\max }$ versus inhibitor concentration. ${ }^{52}$

Propidium Displacement Studies. The affinity of hybrid $\mathbf{6 b}$ for the peripheral anionic site (PAS) of Electrophorus electricus AChE (EeAChE) (type VI-S, Sigma-Aldrich) was tested using propidium iodide (P) (Sigma-Aldrich), a known PAS-specific ligand as previously described by Taylor et al. ${ }^{53} \mathrm{~A}$ shift in the excitation wavelength follows the complexation of propidium iodide and AChE. ${ }^{53 a}$ The fluorescence intensity was monitored by a Jasco 6200 spectrofluorometer (Jasco Europe, Italy) using a $0.5 \mathrm{~mL}$ quartz cuvette at rt. EeAChE $(2 \mathrm{mM})$ was first incubated with $8 \mu \mathrm{M}$ propidium iodide in $1 \mathrm{mM}$ Tris- $\mathrm{HCl}, \mathrm{pH} 8.0$ at rt. The stock solution $(4 \mathrm{mM})$ of the inhibitor was prepared in $\mathrm{MeOH}$. In the back-titration experiments of the propidium-AChE complex by $\mathbf{6} \mathbf{b}$, aliquots of the tested inhibitor (8-56 $\mu \mathrm{M}$, final concentration) were added successively, and fluorescence emission was monitored at $635 \mathrm{~nm}$ upon excitation at $535 \mathrm{~nm}$. Blanks containing propidium alone, inhibitor plus propidium, and EeAChE alone were prepared, and fluorescence emission was determined. Raw data were processed following the method of Taylor and Lappi ${ }^{5 \mathrm{~b}}$ to estimate $K_{\mathrm{D}}$ values assuming a dissociation constant value of propidium from EeAChE equals $0.7 \mu \mathrm{M} .{ }^{54} K_{\mathrm{D}}$ values are expressed as mean \pm standard deviation (SD) of three independent experiments.

Molecular Modeling Studies. The PDB codes 1Q83 and 5K5E, which correspond to the X-ray crystallographic structures of mouse $\mathrm{AChE}^{55}$ and human $\mathrm{BChE}^{56}$ enzymes, were chosen to build up the initial models of the complexes with the selected target compounds $(6 \mathbf{b}, 12 a)$. The $1 \mathrm{Q} 83$ structure was chosen for two reasons. First, the mouse enzyme is highly similar to the human AChE ( $97.5 \%$ sequence identity with $\mathrm{hAChE}$ ), and, particularly, there is complete identity regarding the residues that shape the binding (catalytic, midgorge and peripheral) site. Second, the presence of the 3,8-diamino-6-phenyl-5$\{6-\{1-\{2-[(1,2,3,4-$ tetrahydro-9-acridinyl)amino $]$ ethyl $\}-1 H-1,2,3$-triazol-5-yl\}hexyl\}phenanthridinium (syn-TZ2PA6) ligand in 1Q83 widens the peripheral site, which thus permitted a better accommodation of the target hybrids in the enzyme. A similar rationale motivated the choice of the X-ray structure $5 \mathrm{~K} 5 \mathrm{E}$, which contains the $[(2 R)$-oxolan-2-yl] methyl-4-(9-ethylcarbazol-3-yl)-2methyl-5-oxidanylidene-4,6,7,8 tetrahydro- $1 \mathrm{H}$-quinoline- 3 carboxylate ligand, for BChE. The positioning of the chlorotacrine moiety of the selected hybrids in the catalytic site (and Tyr337, which exhibits a pronounced ligand-dependent conformation) was assisted by the $\mathrm{X}$ - ray structure $1 \mathrm{E} 66$, which corresponds to the complex of huprine $\mathrm{X}$ (containing a chlorotacrine moiety) bound to the Torpedo californica AChE enzyme $\mathrm{e}^{35}$ and the complex of tacrine with human BChE (PDB entry $4 \mathrm{BDS}){ }^{57}$

To achieve a suitable binding mode, compounds $\mathbf{6 b}$ and $\mathbf{1 2 a}$ were manually docked into the binding site of the two proteins following the same protocol reported in previous works. ${ }^{19 c, 58}$ Amber $14^{59}$ was used to perform MD simulations on the previously generated ligandprotein complexes previously generated by docking analysis. In this context, the general Amber force field (GAFF) ${ }^{60}$ was used to parameterize the ligands, and the partial charges were derived at the HF/6-31G(d) level with Gaussian09, ${ }^{61}$ after preliminary optimization of the molecular structure, using the restrained electrostatic potential $(\text { RESP })^{62}$ fitting method implemented in Gaussian09 and Antechamber.

Classical MD simulations were carried out to explore the stability of the complexes for both enantiomers of hybrids $\mathbf{6 b}$ and 12a. To check the structural integrity of the binding mode, MD simulations were run in triplicate for each enantiomeric species. For simulations with $\mathrm{AChE}$, the protonation states reported in previous works were adopted. $^{35,58}$ Protonation states for $\mathrm{BChE}$ at neutral $\mathrm{pH}$ were optimized in accordance with the $\mathrm{p} K_{\mathrm{a}}$ values estimated by PROPKA. $^{63}$

All complexes were solvated with a truncated octahedral (TIP3P) ${ }^{64}$ water box with a layer of $20 \AA$ and neutralized by adding $\mathrm{Na}^{+}$(for $\mathrm{AChE}$ ) or $\mathrm{Cl}^{-}$(for $\mathrm{BChE}$ ) counterions. To maintain the protein structural integrity, the native water network around the chlorotacrine moiety, which mediates relevant interactions with the enzyme, was retained during generation of the starting protein-ligand models.

The complexes were energy-minimized by following a three-stage protocol that involved first all hydrogen atoms, then water molecules, and finally all of the systems with a maximum number of minimization cycles of 10000 for the latter stage. Prior to MD simulations, a preliminary equilibration of the system from 0 to $300 \mathrm{~K}$ was accomplished in six steps, the first being performed at constant volume and the rest at constant pressure. Inspection of the X-ray crystallographic structures of several tacrine-based dual binding site AChEIs revealed that the tacrine unit shares a common binding mode, which in turn mimics the pose found for the AChE and BChE complexes with tacrine. ${ }^{65}$ Accordingly, suitable restraints were imposed to the interactions formed by the chlorotacrine moiety in the catalytic site during equilibration to avoid artefactual structural changes due to the accommodation of the rest of the hybrid compound along the enzyme's gorge. These restraints were gradually reduced and finally eliminated during the first $15 \mathrm{~ns}$ of the MD production.

The SHAKE algorithm ${ }^{66}$ was applied to constrain bonds involving hydrogen atoms. Periodic boundary conditions at constant volume were imposed on the system during the MD simulations. Cutoff for the nonbonded interactions was set to $10 \AA$. The electrostatic interactions beyond the cutoff within the periodic box were computed by applying the particle mesh Ewald (PME) method. ${ }^{67}$ Langevin dynamics with a collision frequency of 1.0 was applied for temperature regulation during the heating. Finally, $50 \mathrm{~ns}$ of MD simulations at constant volume and temperature $(300 \mathrm{~K})$ using the weak-coupling algorithm ${ }^{68}$ with a time constant of 10.0 were run in triplicate for a total of $150 \mathrm{~ns}$ for AChE-(R)-6b, AChE-(S)-6b BChE- $(R)-6 \mathbf{b}, \mathrm{BChE}-(S)-\mathbf{6} \mathbf{b}, \mathrm{BChE}-(R)-\mathbf{1 2} \mathbf{a}$, and BChE-(S)-12a complexes. The time step for saving of trajectory was set to 2 ps. Evaluation of complex stability during MD simulations by means of RMSD analysis for the protein backbone and heavy atoms and for the binding site (protein environment around $8.0 \AA$ from the ligand) as well as water electron density analysis (grid option in the cpptraj module) was performed using the CPPTRAJ module of Amber14.

DPPH Assay for Antioxidant Activity. The 2,2-diphenyl-1picrylhydrazyl (DPPH) free radical assay ${ }^{36,69}$ is a simple method to determine the antioxidant capacity. DPPH, trolox, and $\mathrm{MeOH}$ were purchased from Sigma-Aldrich (Spain). Following the standard procedure, $2 \mathrm{~mL}$ of the antioxidant solution at different concentrations (from 0 to $120 \mu \mathrm{M}$ ) in previously degassed $\mathrm{MeOH}$ was mixed 
with $2 \mathrm{~mL}$ of a $140 \mu \mathrm{M}$ DPPH methanolic solution. After stirring at $\mathrm{rt}$ in the absence of light for $1 \mathrm{~h}$, the absorbance was measured at 515 $\mathrm{nm}$ in a SpectraMax M5 instrument (Molecular Devices, Sunnyvale) using quartz cuvettes. CR-6 (1) was used as the positive control, and the absorbance of $\mathrm{MeOH}$ was measured as a blank. The percentage of absorbance decrease of the DPPH radical (\%I) was calculated using the following expression: $I(\%)=\left(A_{0}-A_{\mathrm{t}} / A_{0}\right) \times 100$, where $A_{0}$ and $A_{\mathrm{t}}$ represent the absorbance of DPPH in the absence of antioxidant and in the presence of a fixed antioxidant concentration after $60 \mathrm{~min}$, respectively.

The half-maximal inhibitory concentration $\left(\mathrm{IC}_{50}\right)$ values were estimated from the corresponding dose-response curves, using computer software GraphPad Prism 5.03 for Windows (GraphPad Software, San Diego), and are expressed as mean \pm standard deviation of single experiments performed in triplicate.

BACE-1 Inhibition Assay. The inhibitory activity of the target CR6 -chlorotacrine hybrids toward human recombinant BACE-1 ( $\beta$ secretase, Invitrogen) was evaluated by employing Panvera peptide as the substrate. ${ }^{70}$ The substrate $(10 \mu \mathrm{L}, 250 \mathrm{nM}$ final concentration $)$ was added to $10 \mu \mathrm{L}$ of the solution of the target compounds or buffer in control wells $(20 \mathrm{mM} \mathrm{NaOAc}, \mathrm{pH} 4.5$, containing $0.1 \% \mathrm{w} / \mathrm{v} 3-[(3-$ cholamidopropyl)dimethylammonio]-1-propanesulfonate (CHAPS)). The BACE-1 enzyme $(10 \mu \mathrm{L}, 12.91 \mathrm{mU})$ was added to start the reaction. The enzyme was left to react at $37{ }^{\circ} \mathrm{C}$ for $1 \mathrm{~h}$. The fluorescence signal was read at $\lambda_{\mathrm{em}}=544 \mathrm{~nm}\left(\lambda_{\mathrm{ex}}=590 \mathrm{~nm}\right)$ after adding $10 \mu \mathrm{L}$ of STOP solution (2.5 M NaOAc). The dimethyl sulfoxide (DMSO) concentration in the final mixture was maintained below $5 \%(\mathrm{v} / \mathrm{v})$ to guarantee no significant loss of enzyme activity. The fluorescence intensities with and without inhibitor were compared, and the percent of inhibition due to the presence of the target compounds was calculated. The background signal was measured in control wells that contained all of the reagents, except BACE-1, and was subtracted. The percent of inhibition due to the presence of increasing concentrations of the test compounds was calculated by the following expression: $100-\left(\mathrm{IF}_{\mathrm{i}} / \mathrm{IF}_{\mathrm{o}} \times 100\right)$, where $\mathrm{IF}_{\mathrm{i}}$ and $\mathrm{IF}_{\mathrm{o}}$ are the fluorescence intensities obtained for BACE-1 in the presence and in the absence of inhibitor, respectively. The $\mathrm{IC}_{50}$ values were extrapolated from the corresponding dose-response curves. Results are expressed as mean \pm standard error of the mean (SEM) of at least two experiments, each performed in triplicate. Data analysis was performed with GraphPad Prism 4.03 software (GraphPad Software Inc.).

A 342 and Tau Aggregation Inhibition Assay in E. coli Cells. The $\mathrm{A} \beta 42$ and tau antiaggregating activities of the target compounds were assessed in E. coli cells, as previously described. ${ }^{20,39}$ E. coli BL21 (DE3) competent cells were transformed with the pET28a vector (Novagen, Inc., Madison, WI), which carries the DNA sequence of A $\beta 42$, or with pTARA, which contains the RNA-polymerase gene of T7 phage (T7RP) under the control of the promoter PBAD, and were then transformed with the pRKT42 vector, encoding four repeats of tau protein in two inserts. M9 minimal medium $(10 \mathrm{~mL})$ containing $50 \mu \mathrm{g} / \mathrm{mL}$ kanamycin (for $\mathrm{A} \beta 42$ overexpression) or $0.5 \%$ of glucose, $50 \mu \mathrm{g} / \mathrm{mL}$ ampicillin, and $12.5 \mu \mathrm{g} / \mathrm{mL}$ chloramphenicol (for tau overexpression) was inoculated with a colony of BL21 (DE3) cells bearing the plasmids. To fresh M9 minimal medium containing 50 $\mu \mathrm{g} / \mathrm{mL}$ kanamycin and $250 \mu \mathrm{M}$ Th-S (for $\mathrm{A} \beta 42$ assay) or $0.5 \%$ of glucose, $50 \mu \mathrm{g} / \mathrm{mL}$ ampicillin, $12.5 \mu \mathrm{g} / \mathrm{mL}$ chloramphenicol, and 250 $\mu \mathrm{M}$ Th-S (for tau assay), the volume of overnight culture necessary to get a 1:500 dilution was added. The cultures were grown at $37^{\circ} \mathrm{C}$ and $250 \mathrm{rpm}$ overnight until cell density reached $\mathrm{OD}_{600}=0.6$. A volume of $980 \mu \mathrm{L}$ of the cultures was transferred into $1.5 \mathrm{~mL}$ Eppendorf tubes that contained $10 \mu \mathrm{L}$ of a solution of the target compound in DMSO and $10 \mu \mathrm{L}$ of isopropyl 1-thio- $\beta$-D-galactopyranoside (IPTG) at 100 $\mathrm{mM}$ (for $\mathrm{A} \beta 42$ assay) or $10 \mu \mathrm{L}$ of arabinose at $25 \%$ (for tau assay), leading to a final inhibitor concentration of $10 \mu \mathrm{M}$. The resulting cultures were grown at $37{ }^{\circ} \mathrm{C}$ and $1400 \mathrm{rpm}$ with a thermomixer (Eppendorf, Hamburg, Germany) overnight. The same amount of DMSO without the target compound was added to the sample as a negative control (maximal amount of $\mathrm{A} / 342$ or tau), whereas noninduced samples (in the absence of IPTG or arabinose) were prepared as positive controls (absence of $\mathrm{A} / 42$ or tau) and to assess the potential intrinsic toxicity of the target compounds.

The inhibitory activity of the target compounds on $A \beta 42$ or tau aggregation was assessed by a previously reported fluorescence assay, ${ }^{20,39}$ using a $2500 \mathrm{mM}$ stock solution of thioflavin-S (Th-S, T1892, Sigma, St. Louis, MO) in double-distilled water (Milli-Q system, Millipore) and measuring the Th-S spectra on an AmincoBowman series 2 luminescence spectrophotometer (Aminco-Bowman $\mathrm{AB} 2$, SLM Aminco, Rochester, NY) in the range $460-600 \mathrm{~nm}$ at 25 ${ }^{\circ} \mathrm{C}$, with an excitation wavelength of $440 \mathrm{~nm}$, slit widths of $4 \mathrm{~nm}$, and an emission wavelength of $485 \mathrm{nM}$. The results are the average of nine independent experiments, each performed in duplicate. As a positive control, we used DP128, a known $\mathrm{A} \beta 42$ and tau antiaggregating compound, ${ }^{20}$ for which percentages of inhibition of $68.2 \pm 2.1$ and $72.2 \pm 2.1$, respectively, were obtained.

PAMPA-BBB Assay for Brain Permeability. The brain permeability $\left(P_{\mathrm{e}}\right)$ of the target compounds was assessed by the in vitro parallel artificial membrane permeability assay, for blood-brain barrier penetration, of $\mathrm{Di}$ et al., ${ }^{40}$ using a lipid extract of porcine brain membrane in a mixture phosphate-buffered saline (PBS)/EtOH 70:30. After assay validation by comparison of the experimental and reported $P_{\mathrm{e}}$ values of a set of 14 commercial drugs (Table $S 1$ of the Supporting Information), the following correlation was obtained: $P_{\mathrm{e}}$ $(\exp )=1.5758 P_{\mathrm{e}}($ lit $)-1.1459\left(R^{2}=0.9241\right)$. From this equation and considering the limits established by $\mathrm{Di}$ et al. for $\mathrm{BBB}$ permeation, ${ }^{40}$ the threshold for high BBB permeation (CNS+) was set at $P_{\mathrm{e}}\left(10^{-6} \mathrm{~cm} \mathrm{~s}^{-1}\right)>5.16$, whereas the range for low $\mathrm{BBB}$ permeation (CNS-) was set at $P_{\mathrm{e}}\left(10^{-6} \mathrm{~cm} \mathrm{~s}^{-1}\right)<2.01$ and that for uncertain $\mathrm{BBB}$ permeation $(\mathrm{CNS} \pm)$ at $5.16>P_{\mathrm{e}}\left(10^{-6} \mathrm{~cm} \mathrm{~s}^{-1}\right)>$ 2.01. Three independent experiments, each performed in triplicate, were carried out for each compound.

In Vivo Efficacy Studies. Animals. The experiments were carried out on male APP/PS1 mice ${ }^{42}$ and wild-type (WT) littermates (C57Bl6J background, bred in own colony located in the University of Barcelona animal facilities) aged 6 months at the beginning of the study. The University of Barcelona Committee on Animal Use and Care approved the protocol (number 411/18). Following the approved experimental protocol, all animals were supervised daily to assess signs of adverse effects during the treatment. A retrospective analysis of the protocol demonstrated that no corrective measures (i.e., use of analgesics) were needed. Animals were housed and tested in compliance with the guidelines provided by the Guide for the Care and Use of Laboratory Animals ${ }^{71}$ and following the European Union directives $(2010 / 63 / \mathrm{EU})$. Animals were maintained under standard animal housing conditions in a normal $12 \mathrm{~h}$ dark-light cycle with free access to food and water.

Acute Toxicity Studies and Dose Selection. A preliminary study was performed to evaluate the acute toxicity of the novel hybrids $\mathbf{4 b}$ and $11 \mathrm{~b}$ and to select the dose to be used in the chronic efficacy studies. Three doses $(5,10$, and $15 \mathrm{mg} / \mathrm{kg})$ of $4 \mathbf{b}$ and $11 \mathbf{b}$ were prepared by dissolving the novel hybrids in 1\% DMSO and $99 \%$ saline. Then, they were injected intraperitoneally (ip) in a volume of $10 \mathrm{~mL} / \mathrm{kg}$ body weight to male WT mice aged 6 months $(n=4$ per compound and dose, total number of animals $=24$ ). Animals were observed by experimented researchers blind to the treatment for the appearance of any physical sign $5 \mathrm{~min}, 10 \mathrm{~min}, 15 \mathrm{~min}, 30 \mathrm{~min}, 1 \mathrm{~h}, 2$ h, $3 \mathrm{~h}, 6 \mathrm{~h}, 8 \mathrm{~h}$, and $24 \mathrm{~h}$ after drug administration.

Chronic Pharmacological Treatment. The novel hybrids $\mathbf{4 b}$ and $11 \mathrm{~b}(10 \mathrm{mg} / \mathrm{kg})$ were dissolved in 1\% DMSO and 99\% saline and were injected intraperitoneally (ip) in a volume of $10 \mathrm{~mL} / \mathrm{kg}$ body weight. Animals were treated once daily for 4 weeks with compounds $4 \mathbf{b}$ and $\mathbf{1 1 b}$ or the corresponding vehicle (WT vehicle, $n=6$; WT $4 \mathbf{b}$, $n=5$; WT 11b, $n=6$; APP/PS1 vehicle, $n=5$; APP/PS1 4b, $n=7$; APP/PS1 11b, $n=6$ ). After 2 days of washing period, animals were subjected to behavioral evaluation.

Behavioral Evaluation of Cognitive Performance. Memory performance was evaluated with the two-object recognition test. On day 1 , mice were placed for 9 min in a V-maze, in which two identical objects were situated at the ends of the arms; the time that the mice spent exploring each object was recorded. Then, $24 \mathrm{~h}$ after the 
training session, animals were placed again for $9 \mathrm{~min}$ in the V-maze, with one of the two familiar objects replaced by a novel object. The time that the animals spent exploring the two objects was recorded, and an object recognition index (RI) was calculated as the difference between the time spent exploring the novel object $\left(T_{\mathrm{N}}\right)$ and the familiar object $\left(T_{\mathrm{F}}\right)$ divided by the total time spent exploring the two objects $\left[\mathrm{RI}=\left(T_{\mathrm{N}}-T_{\mathrm{F}}\right) /\left(T_{\mathrm{N}}+T_{\mathrm{F}}\right)\right]$. Animals exhibiting memory impairments revealed a lower object recognition index.

Tissue Collection. At the end of the behavioral testing, the animals were sacrificed and their brains were removed. One brain hemisphere was dissected on ice, immediately frozen, and stored at $-80{ }^{\circ} \mathrm{C}$ until processing for the protein or RNA quantification. The other brain hemisphere was fixed in $4 \%$ paraformaldehyde and processed for immunohistochemistry.

$A \beta$ Immunohistochemistry. Tissue samples were embedded in paraffin, and coronal sections $(4 \mu \mathrm{m})$ were cut with a microtome. Dewaxed sections were incubated with $98 \%$ formic acid $(3 \mathrm{~min}$ ) and then treated with citrate buffer $(20 \mathrm{~min})$ to enhance antigenicity. Then, the endogenous peroxidases were blocked by incubation in $10 \% \mathrm{MeOH}-1 \% \mathrm{H}_{2} \mathrm{O}_{2}$ solution (15 min). Sections were blocked with $3 \%$ normal horse serum solution and then incubated at $4{ }^{\circ} \mathrm{C}$ overnight with the primary antibody against $\mathrm{A} \beta$ (1:50, Dako, Clone $6 \mathrm{~F} / 3 \mathrm{D})$. Sections were subsequently rinsed and incubated with a biotinylated secondary antibody (Dako), followed by EnVision+ system peroxidase (Dako) and finally with the chromogen diaminobenzidine and $\mathrm{H}_{2} \mathrm{O}_{2}$. Sections were lightly counterstained with hematoxylin. After staining, the sections were dehydrated and cover-slipped for microscopic observation. The $\mathrm{A} \beta$ burden in the cortex was calculated as the percentage of the $\mathrm{A} \beta$ deposition area with respect to the total area in nine representative pictures by each animal, corresponding to the main regions where $\mathrm{A} \beta$ deposition was observed in APP/PS1 mice. Sections from all of the APP/PS1 animals were evaluated using the Analysis tool of Adobe Photoshop CS4 software.

$A \beta$ Soluble Quantification: Enzyme-Linked Immunosorbent Assay (ELISA). Fresh-frozen mouse brain cortex was homogenized in 4 volumes $(\mathrm{w} / \mathrm{v})$ of TBS extraction buffer $(140 \mathrm{mM} \mathrm{NaCl}, 3 \mathrm{mM}$ $\mathrm{KCl}, 25 \mathrm{mM}$ Tris (pH 7.4), $5 \mathrm{mM}$ ethylenediaminetetraacetic acid (EDTA), and protease inhibitor cocktail (Roche Molecular Systems)). The homogenate was spun at $100000 \mathrm{~g} \times 1 \mathrm{~h}$, and the supernatant was saved as the soluble fraction for $\mathrm{A} \beta$ quantification. $\mathrm{A} \beta_{40}$ and $\mathrm{A} \beta_{42}$ Human ELISA kits (Invitrogen Corporation) were used to quantify the levels of $\mathrm{A} \beta_{40}$ and $\mathrm{A} \beta_{42}$ peptides in the brain soluble fractions. Quantitative determination was carried out according to the manufacturer's instructions. $\mathrm{A} \beta_{40}$ and $\mathrm{A} \beta_{42}$ levels were normalized to the total amount of protein from each individual sample (BCA method, Thermo Fisher Scientific).

Protein Oxidation Quantification. The levels of the carbonyl groups introduced into proteins by oxidative reactions were measured using the OxyBlot protein oxidation detection kit (S7150, Merck Millipore) following the manufacturer's instructions. Briefly, frozen samples of the cortex were homogenized in Laemmli buffer $(62.5 \mathrm{mM}$ Tris $-\mathrm{Cl}$, pH 6.8 , containing $2 \%$ sodium dodecyl sulfate (SDS), $10 \%$ glycerol, $0.002 \%$ bromophenol blue, and $50 \mathrm{mM}$ DTT). Protein concentration was determined with the bicinchoninic acid (BCA) method. Equal amounts of protein $(20 \mu \mathrm{g})$ for each sample were prepared for derivatization. The carbonyl groups in the protein side chains were derivatized to 2,4-dinitrophenylhydrazone (DNPhydrazone) by reaction with 2,4-dinitrophenylhydrazine (DNPH). The DNP-derivatized protein samples were loaded and separated by electrophoresis on sodium dodecyl sulfate polyacrylamide gel electrophoresis (SDS-PAGE) (10\%) gels and transferred onto PVDF membranes (Amersham, Germany). Nonspecific bindings were blocked by incubation in 3\% nonfat milk in PBS containing $0.2 \%$ Tween for $1 \mathrm{~h}$ at room temperature. After washing, membranes were incubated overnight at $4{ }^{\circ} \mathrm{C}$ with the primary antibody against the DNP moiety of the proteins. Protein loading was monitored using an antibody against $\beta$-tubulin (1:10 000, Abcam, U.K.). Membranes were then incubated for $1 \mathrm{~h}$ with an anti-rabbit horseradish peroxidase (HRP)-conjugated secondary antibody (1:2000, Dako), and immunocomplexes were revealed by chemiluminescence reagent
(ECL, Amersham). Densitometric quantification was carried out with ImageJ software (NIH). Bands were normalized to $\beta$-tubulin.

SOD2 and $A \beta$ Double-Immunofluorescence. Dewaxed sections were stained with a saturated solution of Sudan black B (Merck) for 30 min to block the autofluorescence of lipofuscin granules present in cell bodies, then rinsed in $70 \% \mathrm{EtOH}$, and washed in distilled water. The sections were treated with $98 \%$ formic acid $(3 \mathrm{~min})$ and with citrate buffer to enhance antigenicity and then incubated at $4{ }^{\circ} \mathrm{C}$ overnight with combinations of primary antibodies against $\mathrm{A} \beta$ (1:50, Dako) and the enzyme superoxide dismutase type 2 (SOD2, 1:500, Stressgen-Gentaur, Belgium). After washing, the sections were incubated with Alexa488 or Alexa546 (1:400, Molecular Probes) fluorescence secondary antibodies against the corresponding host species. After washing, the sections were mounted in Immuno-Fluore mounting medium (ICN Biomedicals), sealed, and dried overnight. Sections were examined with an Olympus BX51 microscope, and five representative pictures taken from the cortex of each animal $(n=5$ per group) were subjected to densitometric quantification using the Adobe Photoshop CS4 software. The SOD2 immunostaining was in reference to the $\mathrm{A} \beta$ plaque area in each picture.

Western Blotting Analysis. Tissue samples were homogenized in lysis buffer (Tris-HCl, pH 7.4, $50 \mathrm{mM}$; $\mathrm{NaCl} 150 \mathrm{mM}$; EDTA 5 $\mathrm{mM}$; and $1 \times$ Triton X-100) containing phosphatase and protease inhibitors (Cocktail II, Sigma). The protein concentration was determined by the Bradford method. Aliquots of $15 \mu \mathrm{g}$ of cortical protein extraction per sample were used. Protein samples were separated by SDS-PAGE $(8-14 \%)$ and transferred onto poly(vinylidene difluoride) (PVDF) membranes (Millipore). Afterward, membranes were blocked in 5\% nonfat milk in Tris-buffered saline (TBS) solution containing $0.1 \%$ Tween 20 for $1 \mathrm{~h}$ at room temperature, followed by overnight incubation at $4{ }^{\circ} \mathrm{C}$ with the primary antibody listed in Table S2 of the Supporting Information. Then, membranes were washed and incubated with the secondary antibody (Table S2) for $1 \mathrm{~h}$ at room temperature. Immunoreactive proteins were visualized with the chemiluminescence-based ChemiLucent detection kit, following the manufacturer's protocol (ECL kit, Millipore), and digital images were acquired using the ChemiDoc XRS+ system (BioRad). Semiquantitative analyses were done using ImageLab software (BioRad), and results were expressed in arbitrary units, considering control protein levels as $100 \%$. Protein loading was routinely monitored by immunodetection of glyceraldehyde-3phosphate dehydrogenase (GAPDH) or $\beta$-tubulin.

RNA Extraction and Gene Expression Determination by Quantitative Polymerase Chain Reaction ( $q P C R)$. Total RNA isolation was carried out using the TRIsure reagent according to the manufacturer's instructions (Bioline reagent, U.K.). The yield, purity, and quality of RNA were determined spectrophotometrically with a NanoDrop ND-1000 (Thermo Scientific) apparatus. RNAs with A260/280 ratios higher than 1.9 were selected. Reversetranscription polymerase chain reaction (RT-PCR) was performed as follows: $2 \mu \mathrm{g}$ of messenger RNA (mRNA) was reverse-transcribed using a high-capacity complementary DNA (cDNA) reverse transcription kit (Applied Biosystems). Real-time quantitative PCR (qPCR) was used to quantify the mRNA expression of oxidative stress and inflammatory genes listed in Table S3 of the Supporting Information. SYBRGreen qPCR was performed in a Step One Plus detection system (Applied Biosystems) employing SYBRGreen PCR master mix (Applied Biosystems). Each reaction mixture contained 2 $\mu \mathrm{g}$ of complementary DNA (cDNA). Data were analyzed utilizing the comparative cycle threshold $(\mathrm{Ct})$ method $(\Delta \Delta \mathrm{Ct})$, where the housekeeping gene expression ( $\beta$-actin) was used to normalize differences in sample loading and preparation. Each sample was analyzed in duplicate, and results represented the $\mathrm{n}$-fold difference of transcription levels among different samples.

Statistical Analyses. Behavioral, western blotting, and qPCR data were analyzed by two-way ANOVA with genotype and treatment as between factors, followed by Tukey's post hoc test or two-tailed Student's t-test when required. $\mathrm{A} \beta$ and SOD2 quantifications were analyzed by one-way ANOVA. The statistical outliers were determined with Grubbs' test and subsequently removed from the 
analysis. In all of the experiments, the significance level was set at $p<$ 0.05 .

Plasma and Microsomal Stability and Metabolite Identification. Stability at Human, Mouse, and Rat Plasma. Human, mouse, and rat plasma pooled from healthy donors, extracted in citrate tubes, was employed in the assay. Plates containing $10 \mu \mathrm{M}$ compound $\mathbf{4 b}$ in plasma (total volume: $50 \mu \mathrm{L}$ ) were incubated at 37 ${ }^{\circ} \mathrm{C}$ at different times $(0,60,180$, and $360 \mathrm{~min})$. Then, acetonitrile $(100 \mu \mathrm{L})$ was added for precipitating plasma protein, and the plate was centrifuged at $46000 \mathrm{~g}$ for $60 \mathrm{~min}$ at $5{ }^{\circ} \mathrm{C}$. The supernatant was taken and analyzed by UPLC-MS/MS for sample quantification, using reverse-phase Acquity UPLC BEH C18 $1.7 \mu \mathrm{m}(2.1 \mathrm{~mm} \times 50 \mathrm{~mm}$, Waters) as the stationary phase, $0.1 \%$ formic acid in water (A) $/ 0.1 \%$ formic acid in acetonitrile (B) as the mobile phase, a flow of $0.6 \mathrm{~mL} /$ min, and the gradient indicated in Table 4.

Table 4. Gradient Used in the UPLC-MS/MS Analysis for Plasma Stability Studies

$\begin{array}{ll}\text { time }(\min ) & \text { A } \\ 0 & \\ 0.1 & \\ 1 & \\ 2 & \\ 2.1 & \\ 2.5 & 95\end{array}$

$\begin{array}{cr}\text { A (\%) } & \text { B (\%) } \\ 95 & 5 \\ 95 & 5 \\ 0 & 100 \\ 0 & 100 \\ 95 & 5 \\ 95 & 5\end{array}$

The chromatographic equipment employed was a Waters Acquity UPLC QSM. Compound concentrations were calculated from the MS peak areas. Values are expressed as the mean of two independent experiments, each performed in triplicate.

Stability at Human, Mouse, and Rat Liver Microsomes. Human, mouse, and rat microsomes from Tebu-Xenotech were employed in the assay, containing $20 \mathrm{mg} / \mathrm{mL}$ protein.

The quantities of reagents, microsomes, and compound $\mathbf{4 b}$ detailed in Table 5 were added to each well of a 96-well microplate.

Table 5. Quantities of Reagents, Microsomes, and Compound $4 \mathrm{~b}$ Used in the Microsomal Stability Assays

\begin{tabular}{lcccc} 
& $\begin{array}{c}\text { blank } \\
(\mu \mathrm{L})\end{array}$ & $\begin{array}{c}\text { human } \\
(\mu \mathrm{L})\end{array}$ & $\begin{array}{c}\text { mouse } \\
(\mu \mathrm{L})\end{array}$ & $\begin{array}{c}\text { rat } \\
(\mu \mathrm{L})\end{array}$ \\
$\begin{array}{l}\text { phosphate buffer Na/K } 50 \mathrm{mM} \\
\mathrm{pH} 7.4\end{array}$ & 295 & 283.5 & 301.3 & 301.3 \\
$\mathrm{MgCl}_{2} 30 \mathrm{mM}$ & 50 & 50 & 50 & 50 \\
$\mathrm{NADP} 10 \mathrm{mM}$ & 50 & 50 & 50 & 50 \\
glucose 6-P 100 mM & 50 & 50 & 50 & 50 \\
glucose 6-P DH 20 U/mL & 25 & 25 & 25 & 25 \\
water & 25 & & & \\
human microsomes & & 36.5 & & \\
mouse microsomes & & & 18.7 & \\
rat microsomes & & & & 18.7 \\
compound 4b $5 \mu \mathrm{M}$ & 5 & 5 & 5 & 5 \\
\hline
\end{tabular}

Plates were incubated at $37^{\circ} \mathrm{C}$, and samples $(75 \mu \mathrm{L})$ were taken at $0,10,20,40$, and $60 \mathrm{~min}$. Samples were transferred to a microplate followed by successive addition of acetonitrile $(75 \mu \mathrm{L})$ and $\mathrm{H}_{2} \mathrm{O}(30$ $\mu \mathrm{L})$ for inactivating the microsomes and for improving the chromatographic conditions, respectively, and were kept at $4{ }^{\circ} \mathrm{C}$. When all of the samples were taken, the plate was centrifuged at $46000 \mathrm{~g}$ for $30 \mathrm{~min}$ at $15^{\circ} \mathrm{C}$. The supernatant was taken and was analyzed in a UPLC-MS/MS system, using reverse-phase Acquity UPLC BEH C18 $1.7 \mu \mathrm{m}(2.1 \mathrm{~mm} \times 50 \mathrm{~mm}$, Waters $)$ as the stationary phase, $0.1 \%$ formic acid in water (A) $/ 0.1 \%$ formic acid in acetonitrile (B) as the mobile phase, a flow of $0.6 \mathrm{~mL} / \mathrm{min}$, and the gradient indicated in Table 6 .

The chromatographic equipment employed was a Waters Acquity UPLC QSM. Compound concentrations were calculated from the MS
Table 6. Gradient Used in the UPLC-MS/MS Analysis for Microsomal Stability Studies

\begin{tabular}{|ccc|}
\hline time $(\min )$ & A (\%) & B (\%) \\
0 & 95 & 5 \\
0.1 & 95 & 5 \\
1 & 0 & 100 \\
2.5 & 0 & 100 \\
2.6 & 95 & 5 \\
3 & 95 & 5 \\
\hline
\end{tabular}

peak areas. Metabolic stability was calculated from the logarithm of the remaining compound at each of the times evaluated. Values are expressed as the mean of two independent experiments, each performed in triplicate.

Metabolite Identification in Human, Mouse, and Rat Liver Microsomes. The supernatants of the microsomal stability assays with human, mouse, and rat liver microsomes were analyzed using a UPLC-MS/MS system consisting of a Waters Acquity H-Class UPLC and a Xevo TQ-D triple quadrupole mass spectrometer, equipped with an electrospray ionization (ESI) source (Waters Corporation, Milford, MA). Chromatographic separation was achieved using an Acquity UPLC BEH C18 $(1.7 \mu \mathrm{m}, 2.1 \mathrm{~mm} \times 50 \mathrm{~mm})$ column, with a UPLC mobile phase A consisting of $0.1 \%$ formic acid in water, a mobile phase B consisting of $0.1 \%$ formic acid in acetonitrile, the gradient indicated in Table 7 , and an injection volume of $4 \mu \mathrm{L}$.

Table 7. Gradient Used in the UPLC-MS/MS Analysis for Metabolite Identification

\begin{tabular}{ccc} 
time $(\min )$ & A (\%) & B (\%) \\
0 & 95 & 5 \\
0.1 & 95 & 5 \\
1 & 0 & 100 \\
2 & 0 & 100 \\
2.1 & 95 & 5 \\
3 & 95 & 5 \\
\hline
\end{tabular}

\section{ASSOCIATED CONTENT}

\section{Supporting Information}

The Supporting Information is available free of charge at https://pubs.acs.org/doi/10.1021/acs.jmedchem.0c00528.

RMSD analyses of the binding of $\mathbf{6 b}$ to hAChE and $\mathrm{hBChE}$ and of 12a to hBChE; MD-averaged $\mathbf{6 b}-\mathrm{hBChE}$ complexes; PAMPA-BBB permeabilities of commercial drugs used for assay validation; antibodies and primers used in Western blot and qPCR studies; relative MS peak areas in the identification of metabolites in human, mouse, and rat liver microsomes; binding mode of the $p$ benzoquinone metabolite of $\mathbf{4 b}$ within hAChE; and copies of ${ }^{1} \mathrm{H}$ and ${ }^{13} \mathrm{C}$ NMR spectra and HPLC chromatograms of target compounds (PDF)

Molecular formula strings (XLS)

FigS2A_R_pose1 (PDB)

FigS2A_R_pose2 (PDB)

FigS2A_R_pose3 (PDB)

FigS2B_S_pose1 (PDB)

FigS2B_S_pose2 (PDB)

FigS2B_S_pose3 (PDB)

Fig3A $\bar{R}-\overline{6 b}+\mathrm{AChE}(\mathrm{PDB})$

Fig3B_S-6b+AChE (PDB)

Fig4A_R-12a+BChE (PDB)

Fig4B_S-12a+BChE (PDB) 


\section{AUTHOR INFORMATION}

\section{Corresponding Author}

Diego Muñoz-Torrero - Laboratory of Medicinal Chemistry (CSIC Associated Unit), Faculty of Pharmacy and Food Sciences, and Institute of Biomedicine (IBUB), University of Barcelona (UB), E-08028 Barcelona, Spain; O orcid.org/ 0000-0002-8140-8555; Phone: (+34) 934024533; Email: dmunoztorrero@ub.edu

\section{Authors}

F. Javier Pérez-Areales - Laboratory of Medicinal Chemistry (CSIC Associated Unit), Faculty of Pharmacy and Food Sciences, and Institute of Biomedicine (IBUB), University of Barcelona (UB), E-08028 Barcelona, Spain

María Garrido - Department of Biological Chemistry, Institute of Advanced Chemistry of Catalonia (IQAC-CSIC), E-08034 Barcelona, Spain

Ester Aso - Department of Pathology and Experimental Therapeutics, Neurosciences Institute, University of Barcelona (UB) and Bellvitge University Hospital-IDIBELL, E-08908 L'Hospitalet de Llobregat, Spain

Manuela Bartolini - Department of Pharmacy and Biotechnology, University of Bologna, I-40126 Bologna, Italy; (1) orcid.org/0000-0002-2890-3856

Angela De Simone - Department of Drug Science and Technology, University of Turin, I-10125 Torino, Italy

Alba Espargaró - Department of Pharmacy, Pharmaceutical Technology and Physical-Chemistry, Faculty of Pharmacy and Food Sciences, and Institute of Nanoscience and Nanotechnology (IN2UB), University of Barcelona (UB), E-08028 Barcelona, Spain

Tiziana Ginex - Department of Nutrition, Food Science and Gastronomy, Faculty of Pharmacy and Food Sciences, IBUB, and Institute of Theoretical and Computational Chemistry (IQTC), University of Barcelona (UB), E-08921 Santa Coloma de Gramenet, Spain

Raimon Sabate - Department of Pharmacy, Pharmaceutical Technology and Physical-Chemistry, Faculty of Pharmacy and Food Sciences, and Institute of Nanoscience and Nanotechnology (IN2UB), University of Barcelona (UB), E-08028 Barcelona, Spain; O orcid.org/0000-0003-3894-2362

Belén Pérez - Department of Pharmacology, Therapeutics, and Toxicology, Autonomous University of Barcelona, E-08193 Bellaterra, Spain

Vincenza Andrisano - Department for Life Quality Studies, University of Bologna, I-47921 Rimini, Italy; (1) orcid.org/ 0000-0003-4396-1904

Dolors Puigoriol-Illamola - Pharmacology Section, Department of Pharmacology, Toxicology and Therapeutic Chemistry, Faculty of Pharmacy and Food Sciences, and Institute of Neuroscience (NeuroUB), University of Barcelona (UB), E-08028 Barcelona, Spain

Mercè Pallàs - Pharmacology Section, Department of Pharmacology, Toxicology and Therapeutic Chemistry, Faculty of Pharmacy and Food Sciences, and Institute of Neuroscience (NeuroUB), University of Barcelona (UB), E-08028 Barcelona,

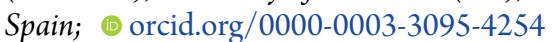

F. Javier Luque - Department of Nutrition, Food Science and Gastronomy, Faculty of Pharmacy and Food Sciences, IBUB, and Institute of Theoretical and Computational Chemistry (IQTC), University of Barcelona (UB), E-08921 Santa Coloma de Gramenet, Spain; 이이이.org/0000-0002-80493567
María Isabel Loza - BioFarma Research Group, Centro Singular de Investigación en Medicina Molecular y Enfermedades Crónicas (CIMUS), Universidade de Santiago de Compostela, E-15782 Santiago de Compostela, Spain

José Brea - BioFarma Research Group, Centro Singular de Investigación en Medicina Molecular y Enfermedades Crónicas (CIMUS), Universidade de Santiago de Compostela, E-15782 Santiago de Compostela, Spain

Isidro Ferrer - Department of Pathology and Experimental Therapeutics, Neurosciences Institute, University of Barcelona (UB) and Bellvitge University Hospital-IDIBELL, E-08908 L'Hospitalet de Llobregat, Spain; CIBERNED, E-28031 Madrid, Spain

Francisco Ciruela - Department of Pathology and Experimental Therapeutics, Neurosciences Institute, University of Barcelona (UB) and Bellvitge University Hospital-IDIBELL, E-08908 L'Hospitalet de Llobregat, Spain

Angel Messeguer - Department of Biological Chemistry, Institute of Advanced Chemistry of Catalonia (IQAC-CSIC), E08034 Barcelona, Spain

Complete contact information is available at:

https://pubs.acs.org/10.1021/acs.jmedchem.0c00528

\section{Author Contributions}

The manuscript was written through contributions of all authors. All authors have given approval to the final version of the manuscript.

\section{Notes}

The authors declare no competing financial interest.

\section{ACKNOWLEDGMENTS}

This work was supported by Ministerio de Ciencia, Innovación y Universidades (MCIU), Agencia Estatal de Investigación (AEI) and FEDER (SAF2017-82771-R, MDM-2017-0767) and Generalitat de Catalunya (GC) (2017SGR106, 2017SGR1746). Fellowships from GC to F.J.P.-A. and from MCIU to D.P.-I. are gratefully acknowledged.

\section{ABBREVIATIONS}

$\mathrm{A} \beta, \quad \beta$-amyloid peptide; $\mathrm{AChE}$, acetylcholinesterase; $\mathrm{AD}$, Alzheimer's disease; APP, amyloid precursor protein; ATCh, acetylthiocholine; BACE-1, $\beta$-site APP cleaving enzyme; $\mathrm{BChE}$, butyrylcholinesterase; CAS, catalytic anionic site; ClTHA, 6-chlorotacrine; CNS, central nervous system; DNP, 2,4-dinitrophenyl; DPPH, 2,2-diphenyl-1-picrylhydrazyl; DTNB, 5,5'-dithiobis(2-nitrobenzoic acid); EeAChE, E. electricus acetylcholinesterase; ELISA, enzyme-linked immunosorbent assay; GAFF, general Amber force field; GAPDH, glyceraldehyde-3-phosphate dehydrogenase; GPX1, glutathione peroxidase 1 ; hAChE, human acetylcholinesterase; hBChE, human butyrylcholinesterase; Hmoxl, heme oxygenase 1; HNE, 4-hydroxy-2-nonenal; iNOS, inducible nitric oxide synthase; ip, intraperitoneally; IPTG, isopropyl 1-thio- $\beta$-Dgalactopyranoside; MCI, mild cognitive impairment; $\mathrm{MD}$, molecular dynamics; Nrf2, nuclear factor-erythroid 2-related factor 2; PAMPA-BBB, parallel artificial membrane permeation assay for blood-brain barrier; PAS, peripheral anionic site; $P_{\mathrm{e}}$, permeability; PME, particle mesh Ewald; qPCR, quantitative polymerase chain reaction; RESP, restrained electrostatic potential; RI, recognition index; ROS, reactive oxygen species; RT-PCR, reverse transcription polymerase chain reaction; SD, standard deviation; SDS-PAGE, sodium dodecyl sulfate 
polyacrylamide gel electrophoresis; SOD2, superoxide dismutase 2; SEM, standard error of the mean; TBS, Tris-buffered saline; THA, tacrine; Th-S, thioflavin-S; TLC, thin-layer chromatography; WT, wild type

\section{REFERENCES}

(1) Alzheimer's Disease International. World Alzheimer Report 2018: The State of the Art of Dementia Research: New Frontiers; Alzheimer's Disease International: London, 2018.

(2) Alzheimer's Disease International. World Alzheimer Report 2019: Attitudes to Dementia; Alzheimer's Disease International: London, 2019.

(3) Cavalli, A.; Bolognesi, M. L.; Minarini, A.; Rosini, M.; Tumiatti, V.; Recanatini, M.; Melchiorre, C. Multi-target-directed ligands to combat neurodegenerative diseases. J. Med. Chem. 2008, 51, 347372.

(4) (a) Lemke, C.; Christmann, J.; Yin, J.; Alonso, J. M.; Serrano, E.; Chioua, M.; Ismaili, L.; Martínez-Grau, M. A.; Beadle, C. D.; Vetman, T.; Dato, F. M.; Bartz, U.; Elsinghorst, P. W.; Pietsch, M.; Müller, C. E.; Iriepa, I.; Wille, T.; Marco-Contelles, J.; Gütschow, M. Chromenones as multineurotargeting inhibitors of human enzymes. ACS Omega 2019, 4, 22161-22168. (b) Wang, Z.; Hu, J.; Yang, X.; Feng, X.; Li, X.; Huang, L.; Chan, A. S. C. Design, synthesis, and evaluation of orally bioavailable quinoline-indole derivatives as innovative multitarget-directed ligands: promotion of cell proliferation in the adult murine hippocampus for the treatment of Alzheimer's disease. J. Med. Chem. 2018, 61, 1871-1894.

(5) Muñoz-Torrero, D. Multitarget anti-Alzheimer Hybrid Compounds: Do They Work in Vivo?. In Design of Hybrid Molecules for Drug Development; Decker, M., Ed.; Elsevier: Amsterdam, 2017; pp 167-192.

(6) (a) Bajda, M.; Łażewska, D.; Godyń, J.; Zaręba, P.; Kuder, K.; Hagenow, S.; Łątka, K.; Stawarska, E.; Stark, H.; Kieć-Kononowicz, K.; Malawska, B. Search for new multi-target compounds against Alzheimer's disease among histamine $\mathrm{H} 3$ receptor ligands. Eur. J. Med. Chem. 2020, 185, No. 111785. (b) Mesiti, F.; Chavarria, D.; Gaspar, A.; Alcaro, S.; Borges, F. The chemistry toolbox of multitargetdirected ligands for Alzheimer's disease. Eur. J. Med. Chem. 2019, 181, No. 111572. (c) Wang, T.; Liu, X.; Guan, J.; Ge, S.; Wu, M.-B.; Lin, J.; Yang, L. Advancement of multi-target drug discoveries and promising applications in the field of Alzheimer's disease. Eur. J. Med. Chem. 2019, 169, 200-223. (d) Gontijo, V. S.; Viegas, F. P. D.; Ortiz, C. J. C.; de Freitas Silva, M.; Damasio, C. M.; Rosa, M. C.; Campos, T. G.; Couto, D. S.; Tranches Dias, K. S.; Viegas, C., Jr. Molecular hybridization as a tool in the design of multi-target directed drug candidates for neurodegenerative diseases. Curr. Neuropharmacol. 2020, 18, 348-407. (e) Gandini, A.; Bartolini, M.; Tedesco, D.; Martinez-Gonzalez, L.; Roca, C.; Campillo, N. E.; Zaldivar-Diez, J.; Perez, C.; Zuccheri, G.; Miti, A.; Feoli, A.; Castellano, S.; Petralla, S.; Monti, B.; Rossi, M.; Moda, F.; Legname, G.; Martinez, A.; Bolognesi, M. L. Tau-centric multitarget approach for Alzheimer's disease: Development of first-in-class dual glycogen synthase kinase $3 \beta$ and tau-aggregation inhibitors. J. Med. Chem. 2018, 61, 7640-7656.

(7) (a) Xu, A.; He, F.; Zhang, X.; Li, X.; Ran, Y.; Wei, C.; James Chou, C.; Zhang, R.; Wu, J. Tacrine-hydroxamate derivatives as multitarget-directed ligands for the treatment of Alzheimer's disease: design, synthesis, and biological evaluation. Bioorg. Chem. 2020, 98, No. 103721. (b) Duarte, Y.; Fonseca, A.; Gutiérrez, M.; AdasmeCarreño, F.; Muñoz-Gutierrez, C.; Alzate-Morales, J.; Santana, L.; Uriarte, E.; Álvarez, R.; Matos, M. J. Novel coumarin-quinoline hybrids: design of multitarget compounds for Alzheimer's disease. ChemistrySelect 2019, 4, 551-558. (c) Zhang, P.; Xu, S.; Zhu, Z.; Xu, J. Multi-target design strategies for the improved treatment of Alzheimer's disease. Eur. J. Med. Chem. 2019, 176, 228-247. (d) Lalut, J.; Santoni, G.; Karila, D.; Lecoutey, C.; Davis, A.; Nachon, F.; Silman, I.; Sussman, J.; Weik, M.; Maurice, T.; Dallemagne, P.; Rochais, C. Novel multitarget-directed ligands targeting acetylcholinesterase and $\sigma 1$ receptors as lead compounds for treatment of Alzheimer's disease: synthesis, evaluation, and structural characterization of their complexes with acetylcholinesterase. Eur. J. Med. Chem. 2019, 162, 234-248. (e) Pisani, L.; Iacobazzi, R. M.; Catto, M.; Rullo, M.; Farina, R.; Denora, N.; Cellamare, S.; Altomare, C. D. Investigating alkyl nitrates as nitric oxide releasing precursors of multitarget acetylcholinesterase-monoamine oxidase $\mathrm{B}$ inhibitors. Eur. J. Med. Chem. 2019, 161, 292-309. (f) Mezeiova, E.; Chalupova, K.; Nepovimova, E.; Gorecki, L.; Prchal, L.; Malinak, D.; Kuca, K.; Soukup, O.; Korabecny, J. Donepezil derivatives targeting amyloid- $\beta$ cascade in Alzheimer's disease. Curr. Alzheimer Res. 2019, 16, 772-800. (g) Pérez-Areales, F. J.; Turcu, A. L.; Barniol-Xicota, M.; Pont, C.; Pivetta, D.; Espargaró, A.; Bartolini, M.; De Simone, A.; Andrisano, V.; Pérez, B.; Sabate, R.; Sureda, F. X.; Vázquez, S.; Muñoz-Torrero, D. A novel class of multitarget anti-Alzheimer benzohomoadamantane-chlorotacrine hybrids modulating cholinesterases and glutamate NMDA receptors. Eur. J. Med. Chem. 2019, 180, 613-626.

(8) Di Domenico, F.; Barone, E.; Perluigi, M.; Butterfield, D. A. Strategy to reduce free radical species in Alzheimer's disease: an update of selected antioxidants. Expert Rev. Neurother. 2015, 15, 1940

(9) (a) Rosini, M.; Simoni, E.; Milelli, A.; Minarini, A.; Melchiorre, C. Oxidative stress in Alzheimer's disease: are we connecting the dots? J. Med. Chem. 2014, 57, 2821-2831. (b) von Bernhardi, R.; Eugenín, J. Alzheimer's disease: redox dysregulation as a common denominator for diverse pathogenic mechanisms. Antioxid. Redox Signaling 2012, 16, 974-1031.

(10) Mecocci, P.; Polidori, M. C. Antioxidant clinical trials in mild cognitive impairment and Alzheimer's disease. Biochim. Biophys. Acta, Mol. Basis Dis. 2012, 1822, 631-638.

(11) Singh, A.; Kukreti, R.; Saso, L.; Kukreti, S. Oxidative stress: a key modulator in neurodegenerative diseases. Molecules 2019, 24, No. 1583 .

(12) Casas, J.; Gorchs, G.; Sánchez-Baeza, F.; Teixidor, P.; Messeguer, A. Inhibition of rat liver microsomal lipid peroxidation elicited by simple 2,2-dimethylchromenes and chromans structurally related to precocenes. J. Agric. Food Chem. 1992, 40, 585-590.

(13) Montoliu, C.; Llansola, M.; Sáez, R.; Yenes, S.; Messeguer, A.; Felipo, V. Prevention of glutamate neurotoxicity in cultured neurons by 3,4-dihydro-6-hydroxy-7-methoxy-2,2-dimethyl-1(2H)-benzopyran (CR-6), a scavenger of nitric oxide. Biochem. Pharmacol. 1999, 58, 255-261.

(14) Sanvicens, N.; Gómez-Vicente, V.; Messeguer, A.; Cotter, T. G. The radical scavenger CR- 6 protects SH-SY5Y neuroblastoma cells from oxidative stress-induced apoptosis: effect on survival pathways. $J$. Neurochem. 2006, 98, 735-747.

(15) Pérez-Asensio, F. J.; de la Rosa, X.; Jiménez-Altayó, F.; Gorina, R.; Martínez, E.; Messeguer, À.; Vila, E.; Chamorro, À.; Planas, A. M. Antioxidant CR-6 protects against reperfusion injury after a transient episode of focal brain ischemia in rats. J. Cereb. Blood Flow Metab. 2010, 30, 638-652.

(16) Vázquez-Jiménez, L.; Garrido, M.; Miceli, M.; Prats, E.; FerrerMontiel, A.; Teixidó, M.; Jimeno, C.; Messeguer, A. Synthesis and in vitro, ex-vivo and in vivo activity of hybrid compounds linking a potent ROS and RNS scavenger activity with diverse substrates addressed to pass across the blood-brain barrier. Eur. J. Med. Chem. 2016, 123, 788-802.

(17) (a) Patel, D. V.; Patel, N. R.; Kanhed, A. M.; Patel, S. P.; Sinha, A.; Kansara, D. D.; Mecwan, A. R.; Patel, S. B.; Upadhyay, P. N.; Patel, K. B.; Shah, D. B.; Prajapati, N. K.; Murumkar, P. R.; Patel, K. V.; Yadav, M. R. Novel multitarget directed triazinoindole derivatives as anti-Alzheimer agents. ACS Chem. Neurosci. 2019, 10, 3635-3661. (b) Nesi, G.; Sestito, S.; Digiacomo, M.; Rapposelli, S. Oxidative stress, mitochondrial abnormalities and proteins deposition: multitarget approaches in Alzheimer's disease. Curr. Top. Med. Chem. 2017, 17, 3062-3079. (c) Rodríguez-Franco, M. I.; Fernández-Bachiller, M. I.; Pérez, C.; Hernández-Ledesma, B.; Bartolomé, B. Novel tacrinemelatonin hybrids as dual-acting drugs for Alzheimer disease, with improved acetylcholinesterase inhibitory and antioxidant properties. J. 
Med. Chem. 2006, 49, 459-462. (d) Fernández-Bachiller, M. I.; Pérez, C.; Campillo, N. E.; Páez, J. A.; González-Muñoz, G. C.; Usán, P.; García-Palomero, E.; López, M. G.; Villarroya, M.; García, A. G.; Martínez, A.; Rodríguez-Franco, M. I. Tacrine-melatonin hybrids as multifunctional agents for Alzheimer's disease, with cholinergic, antioxidant, and neuroprotective properties. ChemMedChem 2009, $4,828-841$.

(18) Mishra, P.; Kumar, A.; Panda, G. Anti-cholinesterase hybrids as multi-target-directed ligands against Alzheimer's disease (19982018). Bioorg. Med. Chem. 2019, 27, 895-930.

(19) (a) Viayna, E.; Sola, I.; Bartolini, M.; De Simone, A.; TapiaRojas, C.; Serrano, F. G.; Sabaté, R.; Juárez-Jiménez, J.; Pérez, B.; Luque, F. J.; Andrisano, V.; Clos, M. V.; Inestrosa, N. C.; MuñozTorrero, D. Synthesis and multitarget biological profiling of a novel family of rhein derivatives as disease-modifying anti-Alzheimer agents. J. Med. Chem. 2014, 57, 2549-2567. (b) Galdeano, C.; Viayna, E.; Sola, I.; Formosa, X.; Camps, P.; Badia, A.; Clos, M. V.; Relat, J.; Ratia, M.; Bartolini, M.; Mancini, F.; Andrisano, V.; Salmona, M.; Minguillón, C.; González-Muñoz, G. C.; Rodríguez-Franco, M. I.; Bidon-Chanal, A.; Luque, F. J.; Muñoz-Torrero, D. Huprine-tacrine heterodimers as anti-amyloidogenic compounds of potential interest against Alzheimer's and prion diseases. J. Med. Chem. 2012, 55, 661669. (c) Camps, P.; Formosa, X.; Galdeano, C.; Muñoz-Torrero, D.; Ramírez, L.; Gómez, E.; Isambert, N.; Lavilla, R.; Badia, A.; Clos, M. V.; Bartolini, M.; Mancini, F.; Andrisano, V.; Arce, M. P.; RodríguezFranco, M. I.; Huertas, Ó.; Dafni, T.; Luque, F. J. Pyrano[3,2c] quinoline-6-chlorotacrine hybrids as a novel family of acetylcholinesterase- and $\beta$-amyloid-directed anti-Alzheimer compounds. J. Med. Chem. 2009, 52, 5365-5379. (d) Di Pietro, O.; Pérez-Areales, F. J.; Juárez-Jiménez, J.; Espargaró, A.; Clos, M. V.; Pérez, B.; Lavilla, R.; Sabaté, R.; Luque, F. J.; Muñoz-Torrero, D. Tetrahydrobenzo[h]$[1,6]$ naphthyridine-6-chlorotacrine hybrids as a new family of antiAlzheimer agents targeting $\beta$-amyloid, tau, and cholinesterase pathologies. Eur. J. Med. Chem. 2014, 84, 107-117.

(20) Espargaró, A.; Pont, C.; Gamez, P.; Muñoz-Torrero, D.; Sabate, R. Amyloid pan-inhibitors: one family of compounds to cope with all conformational diseases. ACS Chem. Neurosci. 2019, 10, 1311-1317.

(21) Di Pietro, O.; Juárez-Jiménez, J.; Muñoz-Torrero, D.; Laughton, C. A.; Luque, F. J. Unveiling a novel transient druggable pocket in BACE-1 through molecular simulations: conformational analysis and binding mode of multisite inhibitors. PLoS One 2017, 12, No. e0177683.

(22) Muñoz-Ruiz, P.; Rubio, L.; García-Palomero, E.; Dorronsoro, I.; del Monte-Millán, M.; Valenzuela, R.; Usán, P.; de Austria, C.; Bartolini, M.; Andrisano, V.; Bidon-Chanal, A.; Orozco, M.; Luque, F. J.; Medina, M.; Martínez, A. Design, synthesis, and biological evaluation of dual binding site acetylcholinesterase inhibitors: new disease-modifying agents for Alzheimer's disease. J. Med. Chem. 2005, $48,7223-7233$.

(23) Pi, R.; Ye, M.; Cheng, Z.; Liu, P. Preparation of TacrineFerulic Acid Containing Compounds for Treatment of Alzheimer's Disease. CN101284812 A, 2008.

(24) Hu, M.-K.; Lu, C.-F. A Facile synthesis of bis-tacrine isosteres. Tetrahedron Lett. 2000, 41, 1815-1818.

(25) Sola, I.; Artigas, A.; Taylor, M. C.; Pérez-Areales, F. J.; Viayna, E.; Clos, M. V.; Pérez, B.; Wright, C. W.; Kelly, J. M.; Muñoz-Torrero, D. Synthesis and biological evaluation of $\mathrm{N}$-cyanoalkyl-, $\mathrm{N}$-aminoalkyl-, and N-guanidinoalkyl-substituted 4-aminoquinoline derivatives as potent, selective, brain permeable antitrypanosomal agents. Bioorg. Med. Chem. 2016, 24, 5162-5171.

(26) (a) Camps, P.; Muñoz-Torrero, D.; Sánchez, L. Stereoselective synthesis of both enantiomers of N-Boc- $\alpha$-aryl- $\gamma$-aminobutyric acids. Tetrahedron Asymmetry 2004, 15, 311-321. (b) Camps, P.; MuñozTorrero, D. Synthesis and applications of (R)- and (S)-pantolactone as chiral auxiliaries. Curr. Org. Chem. 2004, 8, 1339-1380.

(27) Ellman, G. L.; Courtney, K. D.; Andres, V., Jr.; Featherstone, R. $\mathrm{M}$. A new and rapid colorimetric determination of acetylcholinesterase activity. Biochem. Pharmacol. 1961, 7, 88-95.
(28) Wlodek, S. T.; Antosiewicz, J.; McCammon, J. A.; Straatsma, T. P.; Gilson, M. K.; Briggs, J. M.; Humblet, C.; Sussman, J. L. Binding of tacrine and 6-chlorotacrine by acetylcholinesterase. Biopolymers 1996, $38,109-117$.

(29) (a) Scheiner, M.; Dolles, D.; Gunesch, S.; Hoffmann, M.; Nabissi, M.; Marinelli, O.; Naldi, M.; Bartolini, M.; Petralla, S.; Poeta, E.; Monti, B.; Falkeis, C.; Vieth, M.; Hübner, H.; Gmeiner, P.; Maitra, R.; Maurice, T.; Decker, M. Dual-acting cholinesterase-human cannabinoid receptor 2 ligands show pronounced neuroprotection in vitro and overadditive and disease-modifying neuroprotective effects in vivo. J. Med. Chem. 2019, 62, 9078-9102. (b) Maspero, M.; Volpato, D.; Cirillo, D.; Yuan Chen, N.; Messerer, R.; Sotriffer, C.; De Amici, M.; Holzgrabe, U.; Dallanoce, C. Tacrine-xanomeline and tacrine-iperoxo hybrid ligands: synthesis and biological evaluation at acetylcholinesterase and M1 muscarinic acetylcholine receptors. Bioorg. Chem. 2020, 96, 103633. (c) Fancellu, G.; Chand, K.; Tomás, D.; Orlandini, E.; Piemontese, L.; Silva, D. F.; Cardoso, S. M.; Chaves, S.; Santos, M. A. Novel tacrine-benzofuran hybrids as potential multi-target drug candidates for the treatment of Alzheimer's disease. J. Enzyme Inhib. Med. Chem. 2020, 35, 211-226. (d) Cheng, X.; Gu, J.; Pang, Y.; Liu, J.; Xu, T.; Li, X.; Hua, Y.; Newell, K. A.; Huang, X.-F.; Yu, Y.; Liu, Y. Tacrine-hydrogen sulfide donor hybrid ameliorates cognitive impairment in the aluminum chloride mouse model of Alzheimer's disease. ACS Chem. Neurosci. 2019, 10, 35003509.

(30) Savini, L.; Gaeta, A.; Fattorusso, C.; Catalanotti, B.; Campiani, G.; Chiasserini, L.; Pellerano, C.; Novellino, E.; McKissic, D.; Saxena, A. Specific targeting of acetylcholinesterase and butyrylcholinesterase recognition sites. Rational design of novel, selective, and highly potent cholinesterase inhibitors. J. Med. Chem. 2003, 46, 1-4.

(31) (a) Recanatini, M.; Cavalli, A.; Belluti, F.; Piazzi, L.; Rampa, A.; Bisi, A.; Gobbi, S.; Valenti, P.; Andrisano, V.; Bartolini, M.; Cavrini, V. SAR of 9-amino-1,2,3,4-tetrahydroacridine-based acetylcholinesterase inhibitors: synthesis, enzyme inhibitory activity, QSAR, and structurebased CoMFA of tacrine analogues. J. Med. Chem. 2000, 43, 20072018. (b) Wlodek, S. T.; Antosiewicz, J.; McCammon, J. A.; Straatsma, T. P.; Gilson, M. K.; Briggs, J. M.; Humblet, C.; Sussman, J. L. Binding of tacrine and 6-chlorotacrine by acetylcholinesterase. Biopolymers 1996, 38, 109-117.

(32) (a) Hoffmann, M.; Stiller, C.; Endres, E.; Scheiner, M.; Gunesch, S.; Sotriffer, C.; Maurice, T.; Decker, M. Highly selective butyrylcholinesterase inhibitors with tunable duration of action by chemical modification of transferable carbamate units exhibit pronounced neuroprotective effect in an Alzheimer's disease mouse model. J. Med. Chem. 2019, 62, 9116-9140. (b) Darvesh, S. Butyrylcholinesterase as a diagnostic and therapeutic target for Alzheimer's disease. Curr. Alzheimer Res. 2016, 13, 1173-1177.

(33) Elsinghorst, P. W.; Cieslik, J. S.; Mohr, K.; Tränkle, C.; Gütschow, M. First gallamine-tacrine hybrid: design and characterization at cholinesterases and the $\mathrm{M}_{2}$ muscarinic receptor. J. Med. Chem. 2007, 50, 5685-5695.

(34) (a) Camps, P.; Formosa, X.; Galdeano, C.; Gómez, T.; MuñozTorrero, D.; Scarpellini, M.; Viayna, E.; Badia, A.; Clos, M. V.; Camins, A.; Pallàs, M.; Bartolini, M.; Mancini, F.; Andrisano, V.; Estelrich, J.; Lizondo, M.; Bidon-Chanal, A.; Luque, F. J. Novel donepezil-based inhibitors of acetyl- and butyrylcholinesterase and acetylcholinesterase-induced $\beta$-amyloid aggregation. J. Med. Chem. 2008, 51, 3588-3598. (b) Alonso, D.; Dorronsoro, I.; Rubio, L.; Muñoz, P.; García-Palomero, E.; Del Monte, M.; Bidon-Chanal, A.; Orozco, M.; Luque, F. J.; Castro, A.; Medina, M.; Martínez, A. Donepezil-tacrine hybrid related derivatives as new dual binding site inhibitors of AChE. Bioorg. Med. Chem. 2005, 13, 6588-6597.

(35) Dvir, H.; Wong, D. M.; Harel, M.; Barril, X.; Orozco, M.; Luque, F. J.; Muñoz-Torrero, D.; Camps, P.; Rosenberry, T. L.; Silman, I.; Sussman, J. L. 3D structure of Torpedo californica acetylcholinesterase complexed with huprine $\mathrm{X}$ at $2.1 \AA$ resolution: kinetic and molecular dynamic correlates. Biochemistry 2002, 41, 2970-2981. 
(36) (a) Blois, M. S. Antioxidant determinations by the use of a stable free radical. Nature 1958, 181, 1199-1200. (b) BrandWilliams, W.; Cuvelier, M. E.; Berset, C. Use of a free radical method to evaluate antioxidant activity. LWT-Food Sci. Technol. 1995, 28, 25-30.

(37) (a) Hu, H.; Chen, Z.; Xu, X.; Xu, Y. Structure-based survey of the binding modes of BACE1 inhibitors. ACS Chem. Neurosci. 2019, 10, 880-889. (b) Hsiao, C.-C.; Rombouts, F.; Gijsen, H. J. M. New evolutions in the BACE1 inhibitor field from 2014 to 2018. Bioorg. Med. Chem. Lett. 2019, 29, 761-777. (c) Mancini, F.; De Simone, A.; Andrisano, V. Beta-secretase as a target for Alzheimer's disease drug discovery: an overview of in vitro methods for characterization of inhibitors. Anal. Bioanal. Chem. 2011, 400, 1979-1996.

(38) (a) Fernández-Bachiller, M. I.; Pérez, C.; Monjas, L.; Rademann, J.; Rodríguez-Franco, M. I. New tacrine-4-oxo-4Hchromene hybrids as multifunctional agents for the treatment of Alzheimer's disease, with cholinergic, antioxidant, and $\beta$-amyloidreducing properties. J. Med. Chem. 2012, 55, 1303-1317. (b) Fu, H.; Li, W.; Luo, J.; Lee, N. T. K.; Li, M.; Tsim, K. W. K.; Pang, Y.; Youdim, M. B. H.; Han, Y. Promising anti-Alzheimer's dimer bis(7)tacrine reduces $\beta$-amyloid generation by directly inhibiting BACE-1 activity. Biochem. Biophys. Res. Commun. 2008, 366, 631-636.

(39) (a) Espargaró, A.; Medina, A.; Di Pietro, O.; Muñoz-Torrero, D.; Sabate, R. Ultra rapid in vivo screening for anti-Alzheimer antiamyloid drugs. Sci. Rep. 2016, 6, No. 23349. (b) Pouplana, S.; Espargaró, A.; Galdeano, C.; Viayna, E.; Sola, I.; Ventura, S.; MuñozTorrero, D.; Sabate, R. Thioflavin-S staining of bacterial inclusion bodies for the fast, simple, and inexpensive screening of amyloid aggregation inhibitors. Curr. Med. Chem. 2014, 21, 1152-1159.

(40) Di, L.; Kerns, E. H.; Fan, K.; McConnell, O. J.; Carter, G. T. High throughput artificial membrane permeability assay for bloodbrain barrier. Eur. J. Med. Chem. 2003, 38, 223-232.

(41) Sola, I.; Aso, E.; Frattini, D.; López-González, I.; Espargaró, A.; Sabaté, R.; Di Pietro, O.; Luque, F. J.; Clos, M. V.; Ferrer, I.; MuñozTorrero, D. Novel levetiracetam derivatives that are effective against the Alzheimer-like phenotype in mice: synthesis, in vitro, ex vivo, and in vivo efficacy studies. J. Med. Chem. 2015, 58, 6018-6032.

(42) Borchelt, D. R.; Ratovitski, T.; van Lare, J.; Lee, M. K.; Gonzales, V.; Jenkins, N. A.; Copeland, N. G.; Price, D. L.; Sisodia, S. $S$. Accelerated amyloid deposition in the brains of transgenic mice coexpressing mutant presenilin 1 and amyloid precursor proteins. Neuron 1997, 19, 939-945.

(43) Vogel, C.; Marcotte, E. M. Insights into the regulation of protein abundance from proteomic and transcriptomic analyses. Nat. Rev. Genet. 2012, 13, 227-232.

(44) Cheignon, C.; Tomas, M.; Bonnefont-Rousselot, D.; Faller, P.; Hureau, C.; Collin, F. Oxidative stress and the amyloid beta peptide in Alzheimer's disease. Redox Biol. 2018, 14, 450-464.

(45) (a) Patocka, J.; Jun, D.; Kuca, K. Possible role of hydroxylated metabolites of tacrine in drug toxicity and therapy of Alzheimer's disease. Curr. Drug Metab. 2008, 9, 332-335. (b) Spaldin, V.; Madden, S.; Pool, W.; Woolf, T.; Park, B. The effect of enzyme inhibition on the metabolism and activation of tacrine by human liver microsomes. Br. J. Clin. Pharmacol. 1994, 38, 15-22. (c) Madden, S.; Woolf, T. F.; Pool, W. F.; Park, B. K. An investigation into the formation of stable, protein-reactive and cytotoxic metabolites from tacrine in vitro. Biochem. Pharmacol. 1993, 46, 13-20.

(46) Nepovimova, E.; Korabecny, J.; Dolezal, R.; Babkova, K.; Ondrejicek, A.; Jun, D.; Sepsova, V.; Horova, A.; Hrabinova, M.; Soukup, O.; Bukum, N.; Jost, P.; Muckova, L.; Kassa, J.; Malinak, D.; Andrs, M.; Kuca, K. Tacrine-trolox hybrids: A novel class of centrally active, nonhepatotoxic multi-target-directed ligands exerting anticholinesterase and antioxidant activities with low in vivo toxicity. $J$. Med. Chem. 2015, 58, 8985-9003.

(47) (a) Kamal-Eldin, A.; Appelqvist, L.-Å. The chemistry and antioxidant properties of tocopherols and tocotrienols. Lipids 1996, 31, 671-701. (b) Christen, S.; Woodall, A. A.; Shigenaga, M. K.; Southwell-Keely, P. T.; Duncan, M. W.; Ames, B. N. $\gamma$-Tocopherol traps mutagenic electrophiles such as NOx and complements $\alpha$ - tocopherol: Physiological implications. Proc. Natl. Acad. Sci. U.S.A. 1997, 94, 3217-3222.

(48) (a) Siegel, D.; Bolton, E. M.; Burr, J. A.; Liebler, D. C.; Ross, D. The reduction of $\alpha$-tocopherolquinone by human $\mathrm{NAD}(\mathrm{P}) \mathrm{H}$ :quinone oxidoreductase: The role of $\alpha$-tocopherolhydroquinone as a cellular antioxidant. Mol. Pharmacol. 1997, 52, 300-305. (b) Kohar, I.; Baca, M.; Suarna, C.; Stocker, R.; Southwell-Keely, P. T. Is $\alpha$-tocopherol a reservoir for $\alpha$-tocopheryl hydroquinone? Free Radical Biol. Med. 1995, 19, 197-207. (c) Takaaki, H.; Akio, K.; Masao, N.; Mamoru, T.; Hharuhisa, S. Reduction of $\alpha$-tocopherolquinone to $\alpha$ tocopherolhydroquinone in rat hepatocytes. Biochem. Pharmacol. 1992, 44, 489-493.

(49) Yenes, S.; Commandeur, J. N. M.; Vermeulen, N. P. E.; Messeguer, A. In vitro biotransformation of 3,4-dihydro-6-hydroxy2,2-dimethyl-7-methoxy-1(2H)-benzopyran (CR-6), a potent lipid peroxidation inhibitor and nitric oxide scavenger, in rat liver microsomes. Chem. Res. Toxicol. 2004, 17, 904-913.

(50) Słoczyńska, K.; Gunia-Krzyżak, A.; Koczurkiewicz, P.; WójcikPszczoła, K.; Żelaszczyk, D.; Popiól, J.; Pękala, E. Metabolic stability and its role in the discovery of new chemical entities. Acta Pharm. 2019, 69, 345-361.

(51) Cornish-Bowden, A. A simple graphical method for determining the inhibition constants of mixed, uncompetitive and non-competitive inhibitors. Biochem. J. 1974, 137, No. 143e144.

(52) Silverman, R. B. The Organic Chemistry of Enzyme-Catalyzed Reactions, 1st ed.; Academic Press: San Diego, 2000.

(53) (a) Taylor, P.; Lwebuga-Mukasa, J.; Lappi, S.; Rademacher, J. Propidium - a fluorescent probe for a peripheral anionic site on acetylcholinesterase. Mol. Pharmacol. 1974, 10, 703-708. (b) Taylor, P.; Lappi, S. Interaction of fluorescence probes with acetylcholinesterase, the site and specificity of propidium binding. Biochemistry 1975, 14, 1989-1997.

(54) Nunes-Tavares, N.; Nery da Matta, A.; Batista e Silva, C. M.; Araújo, G. M. N.; Louro, S. R. W.; Hassón-Voloch, A. Inhibition of acetylcholinesterase from Electrophorus electricus (L.) by tricyclic antidepressants. Int. J. Biochem. Cell Biol. 2002, 34, 1071-1079.

(55) Bourne, Y.; Kolb, H. C.; Radić, Z.; Sharpless, K. B.; Taylor, P.; Marchot, P. Freeze-frame inhibitor captures acetylcholinesterase in a unique conformation. Proc. Natl. Acad. Sci. U.S.A. 2004, 101, 14491454.

(56) Dighe, S. N.; Deora, G. S.; De la Mora, E.; Nachon, F.; Chan, S.; Parat, M. O.; Brazzolotto, X.; Ross, B. P. Discovery and structureactivity relationships of a highly selective butyrylcholinesterase inhibitor by structure-based virtual screening. J. Med. Chem. 2016, 59, 7683-7689.

(57) Nachon, F.; Carletti, E.; Ronco, C.; Trovaslet, M.; Nicolet, Y.; Jean, L.; Renard, P. Y. Crystal structures of human cholinesterases in complex with huprine $\mathrm{W}$ and tacrine: elements of specificity for antiAlzheimer's drugs targeting acetyl- and butyryl-cholinesterase. Biochem J. 2013, 453, 393-399.

(58) Camps, P.; El Achab, R.; Morral, J.; Muñoz-Torrero, D.; Badia, A.; Baños, J. E.; Vivas, N. M.; Barril, X.; Orozco, M.; Luque, F. J. New tacrine-huperzine A hybrids (huprines): highly potent tight-binding acetylcholinesterase inhibitors of interest for the treatment of Alzheimer's disease. J. Med. Chem. 2000, 43, 4657-4666.

(59) Case, D. A.; Babin, V.; Berryman, J. T.; Betz, R. M.; Cai, Q.; Cerutti, D. S.; Cheatham, T. E., III; Darden, T. A.; Duke, R. E.; Gohlke, H.; Goetz, A. W.; Gusarov, S.; Homeyer, N.; Janowski, P.; Kaus, J.; Kolossváry, I.; Kovalenko, A.; Lee, T. S.; LeGrand, S.; Luchko, T.; Luo, R.; Madej, B.; Merz, K. M.; Paesani, F.; Roe, D. R.; Roitberg, A.; Sagui, C.; Salomon-Ferrer, R.; Seabra, G.; Simmerling, C. L.; Smith, W.; Swails, J.; Walker, R. C.; Wang, J.; Wolf, R. M.; Wu, X.; Kollman, P. A. AMBER 14; University of California: San Francisco, 2014.

(60) Wang, J.; Wolf, R. M.; Caldwell, J. W.; Kollman, P. A.; Case, D. A. Development and testing of a general Amber force field. J. Comput. Chem. 2004, 25, 1157-1174.

(61) Frisch, M. J.; Trucks, G. W.; Schlegel, H. B.; Scuseria, G. E.; Robb, M. A.; Cheeseman, J. R.; Scalmani, G.; Barone, V.; Mennucci, 
B.; Petersson, G. A.; Nakatsuji, H.; Caricato, M.; Li, X.; Hratchian, H. P.; Izmaylov, A. F.; Bloino, J.; Zheng, G.; Sonnenberg, J. L.; Hada, M.; Ehara, M.; Toyota, K.; Fukuda, R.; Hasegawa, J.; Ishida, M.; Nakajima, T.; Honda, Y.; Kitao, O.; Nakai, H.; Vreven, T.; Montgomery, J. A., Jr.; Peralta, J. E.; Ogliaro, F.; Bearpark, M.; Heyd, J. J.; Brothers, E.; Kudin, K. N.; Staroverov, V. N.; Kobayashi, R.; Normand, J.; Raghavachari, K.; Rendell, A.; Burant, J. C.; Iyengar, S. S.; Tomasi, J.; Cossi, M.; Rega, N.; Millam, J. M.; Klene, M.; Knox, J. E.; Cross, J. B.; Bakken, V.; Adamo, C.; Jaramillo, J.; Gomperts, R.; Stratmann, R. E.; Yazyev, O.; Austin, A. J.; Cammi, R.; Pomelli, C.; Ochterski, J. W.; Martin, R. L.; Morokuma, K.; Zakrzewski, V. G.; Voth, G. A.; Salvador, P.; Dannenberg, J. J.; Dapprich, S.; Daniels, A. D.; Farkas, Ö.; Foresman, J. B.; Ortiz, J. V.; Cioslowski, J.; Fox, D. J. Gaussian 09; Gaussian, Inc.: Wallingford, CT, 2009.

(62) Wang, J.; Cieplak, P.; Kollman, P. A. How well does a restrained electrostatic potential (RESP) model perform in calculating conformational energies of organic and biological molecules? J. Comput. Chem. 2000, 21, 1049-1074.

(63) (a) Søndergaard, C. R.; Olsson, M. H. M.; Rostkowski, M.; Jensen, J. H. Improved treatment of ligands and coupling effects in empirical calculation and rationalization of $\mathrm{pKa}$ values. J. Chem. Theory Comput. 2011, 7, 2284-2295. (b) Olsson, M. H. M.; Søndergaard, C. R.; Rostkowski, M.; Jensen, J. H. PROPKA3: consistent treatment of internal and surface residues in empirical $\mathrm{pKa}$ predictions. J. Chem. Theory Comput. 2011, 7, 525-537.

(64) Jorgensen, W. L.; Chandrasekhar, J.; Madura, J. D.; Impey, R. W.; Klein, M. L. Comparison of simple potential functions for simulating liquid water. J. Chem. Phys. 1983, 79, 926-935.

(65) Harel, M.; Schalk, I.; Ehret-Sabatier, L.; Bouet, F.; Goeldner, M.; Hirth, C.; Axelsen, P. H.; Silman, I.; Sussman, J. L. Quaternary ligand binding to aromatic residues in the active-site gorge of acetylcholinesterase. Proc. Natl. Acad. Sci. U.S.A. 1993, 90, 90319035.

(66) Ryckaert, J.-P.; Ciccotti, G.; Berendsen, H. J. C. Numerical integration of the cartesian equations of motion of a system with constraints: molecular dynamics of n-alkanes. J. Comput. Phys. 1977, 23, 327-341.

(67) Darden, T.; York, D.; Pedersen, L. Particle mesh Ewald: an N. $\log (\mathrm{N})$ method for Ewald sums in large systems. J. Chem. Phys. 1993, 98, 10089-10092.

(68) Berendsen, H. J. C.; Postma, J. P. M.; van Gunsteren, W. F.; DiNola, A.; Haak, J. R. Molecular dynamics with coupling to an external bath. J. Chem. Phys. 1984, 81, 3684-3690.

(69) Molyneux, P. The use of the stable free radical diphenylpicrylhydrazyl (DPPH) for estimating antioxidant activity. Songklanakarin J. Sci. Technol. 2004, 26, 211-219.

(70) Tarozzi, A.; Bartolini, M.; Piazzi, L.; Valgimigli, L.; Amorati, R.; Bolondi, C.; Djemil, A.; Mancini, F.; Andrisano, V.; Rampa, A. From the dual function lead AP2238 to AP2469, a multi-target-directed ligand for the treatment of Alzheimer's disease. Pharmacol. Res. Perspect. 2014, 2, No. e00023.

(71) Clark, J. D.; Gebhart, G. F.; Gonder, J. C.; Keeling, M. E.; Kohn, D. F. The 1996 guide for the care and use of laboratory animals. ILAR J. 1997, 38, 41-48. 